\title{
$\mathrm{PH} 96$
}

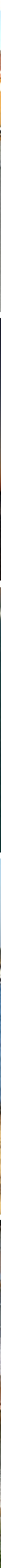



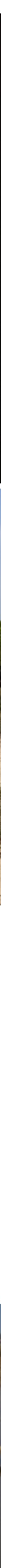

Agradecemos a Luis Colmenero Ruiz, Gerardo Jesús García Olivares y Manuela Fuentes su colaboración para ilustrar gráficamente esta sección. Pueden encontrar más imágenes en el álbum sobre Huelva y la costa occidental en el perfil de Facebook del IAPH. 


\section{Paisajes mutantes de Huelva y la costa occidental}

Juan A. Márquez Domínguez | Dpto. de Historia, Geografía y Antropología de la Universidad de Huelva

URL de la contribución <www.iaph.es/revistaph/index.php/revistaph/issue/view/4287>

\section{RESUMEN}

La comarca de Huelva y la costa occidental se extiende por 1.394 kilómetros cuadrados adosados a una planicie litoral, articulada y diseccionada por los ríos Guadiana, Carreras, Piedras y Tinto-Odiel. Estos ríos conforman en su desembocadura estuarios y marismas, precedidas de caños y esteros, que entablan una enconada lucha con las aguas del mar, cuyas batallas se impresionan en spits o barras de arena. La ocupación de este territorio se inició en los promontorios que garantizaron la seguridad necesaria para la defensa de la vida y las haciendas. Así, los núcleos urbanos más antiguos se localizan en las lomas más elevadas. Los ríos constituyeron, con sus puertos fluviales, las vías de comunicación más importantes. Por ella transitaron hombres y mercancías de un ruedo agrícola consagrado a la trilogía mediterránea y a productos que, como la almendra y los higos, permitieron la travesía de la aventura colombina.

Sin embargo, recientemente, la inercia de la historia se ha roto. La comarca, con apenas el $14 \%$ del territorio provincial, concentra más del $62 \%$ de la población, 323.087 personas en 2017. De forma disruptiva, los paisajes tradicionales han cambiado con el acercamiento a la costa de actividades emergentes como la industria, la agricultura de vanguardia y el turismo. En la carrera de los paisajes mutantes, un pequeño núcleo de pescadores, que no sobresalía de los de su entorno, Huelva, se ha ido convirtiendo en la ciudad primada, articulando desde su puerto un potente tejido productivo industrial, comercial y de servicios.

\section{Palabras clave}

Agricultura | Comarca | Costa occidental | Huelva | Industrialización | Marisma | Paisaje | Territorio | Turismo | 


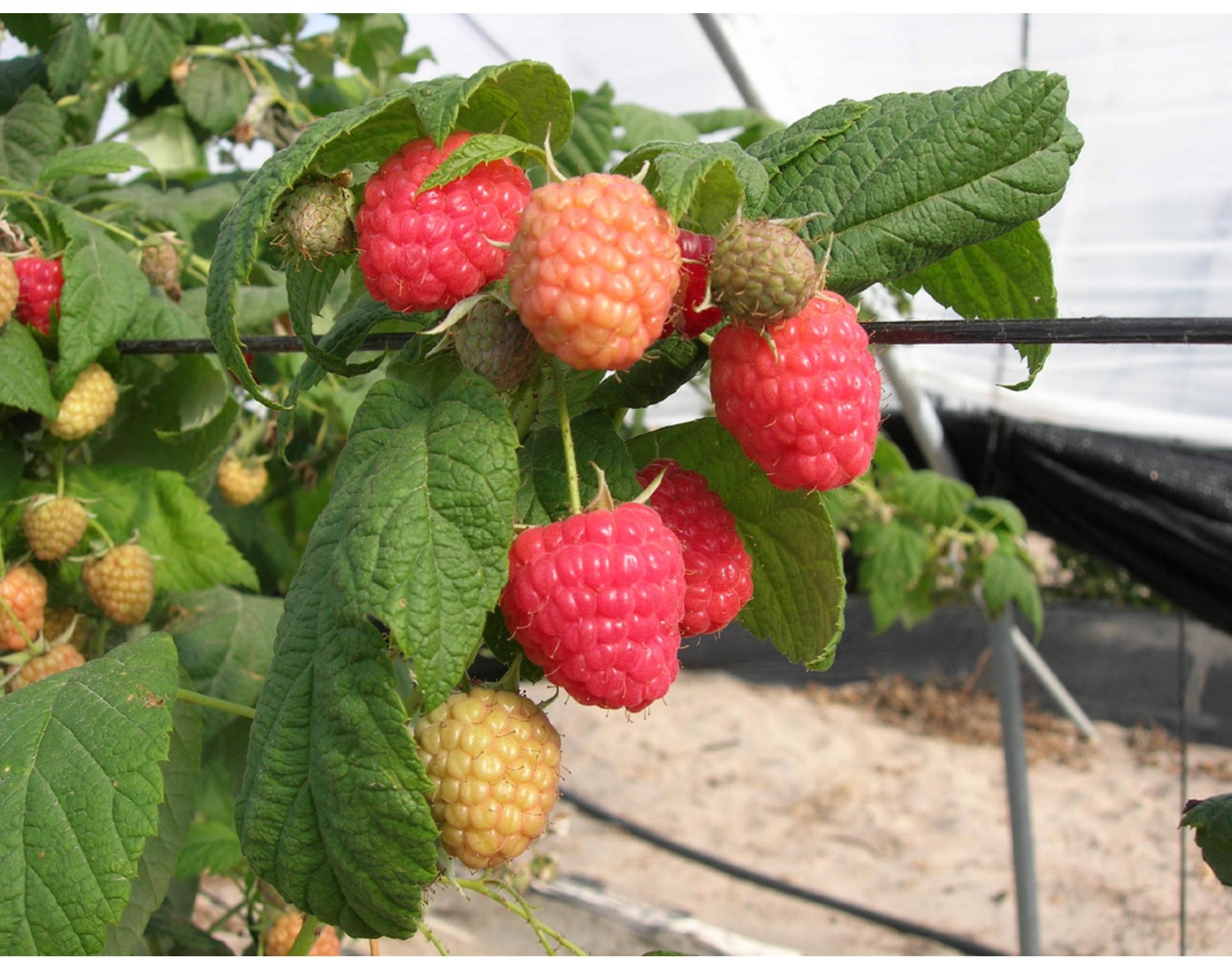

La introducción de berries en la costa occidental de Huelva ha originado una verdadera revolución agraria. Frambuesas | foto Juan A. Márquez y grupo de investigación Instituto de Desarrollo Local 


\section{EL TERRITORIO}

El mundo suratlántico entra en España por la frontera portuguesa, al poniente, y recorre hacia el oriente las provincias de Huelva y Cádiz. En este amplio arco, una comarca, la de Huelva y la costa occidental, se ha ido conformando como un espacio anfibio, que todavía no ha acabado su evolución.

Entre los estuarios de los ríos Guadiana y Tinto-Odiel, se fueron asentando puertos y ciudades, abrigados en las atalayas de formaciones miocénicas, en emplazamientos que hoy se ven como afortunados y herederos de la cultura tartésica.

El espacio de Huelva y la costa occidental se enmarca en un territorio que puede ser perfectamente identificado por su historia y su morfología litoral y de promontorios: marismas y arenas lamidas por el Atlántico al sur; de limos y arcillas que drenan los ríos Tinto-Odiel por el este; de estuarios y marismas del viejo Anás por el oeste; y de campos y glacis hacia el norte, haciendo la transición a la vasta comarca del Andévalo.

La herencia de este pasado ha perfilado un espacio rico, con los centros urbanos más poblados y activos de la provincia, catapultados hoy por la puesta

Perfil territorial de Huelva y la Costa Occidental | fuente Instituto Geográfico Nacional en valor de amplios arenales donde se cultivan fresas, arándanos, naranjos,

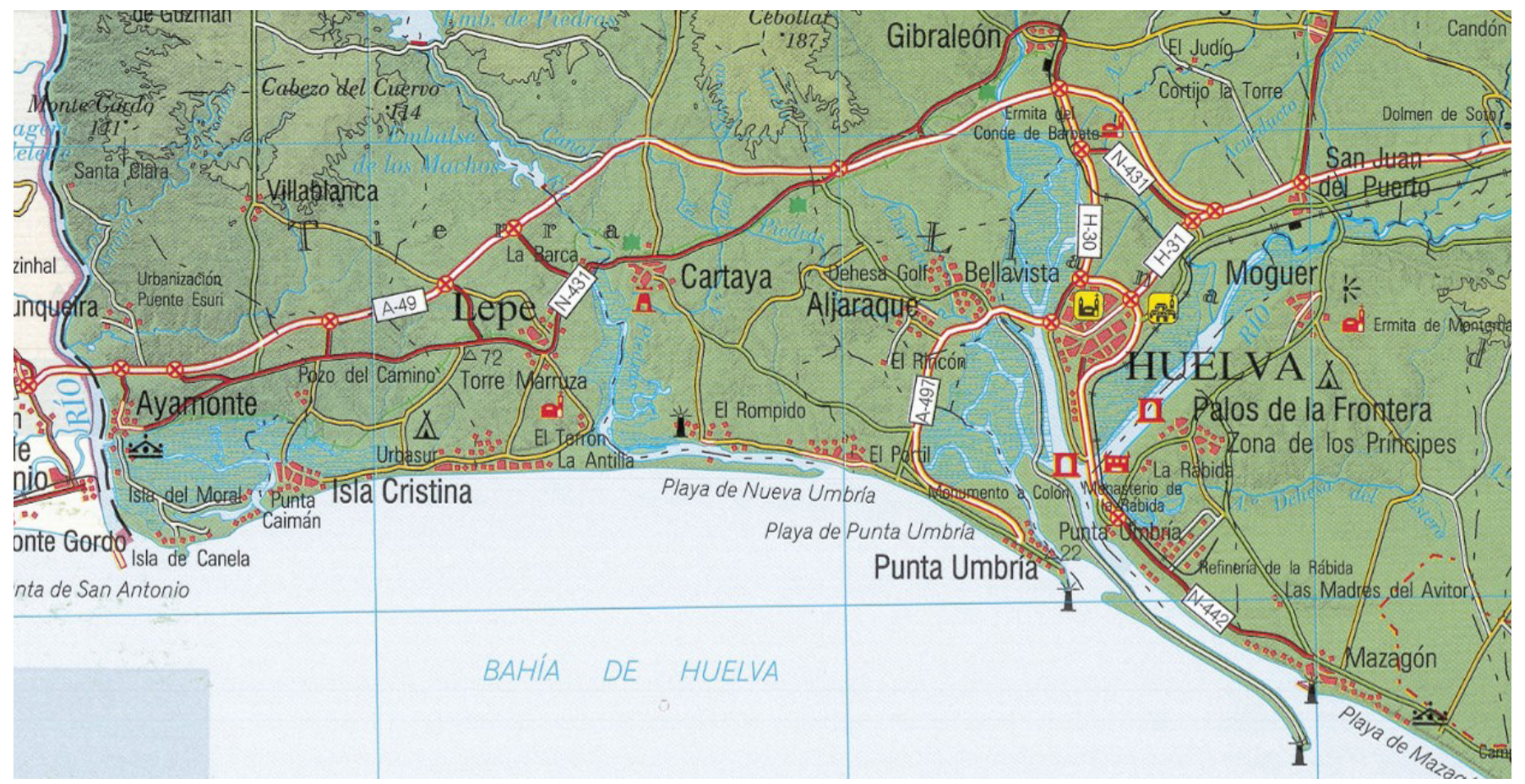




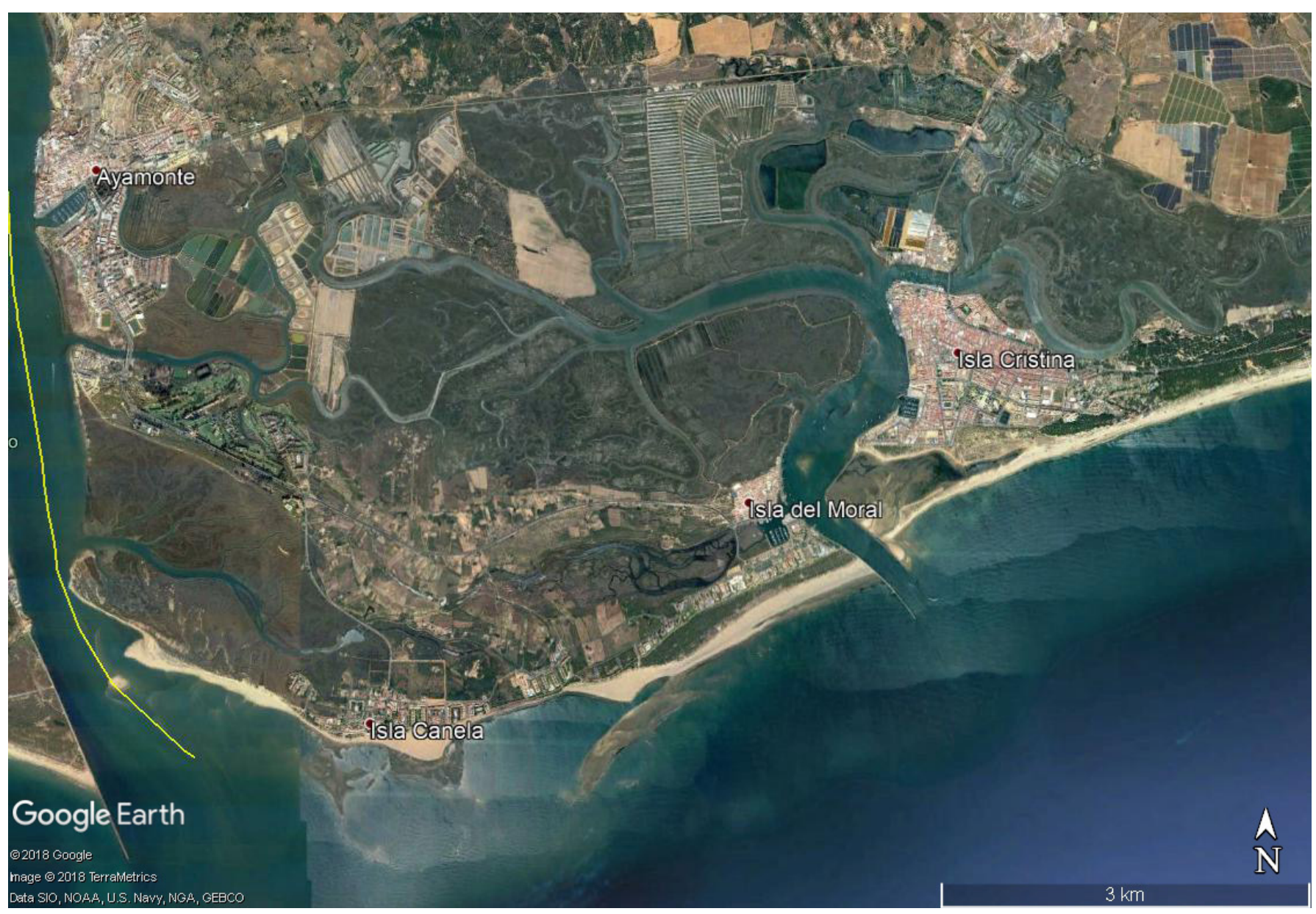

Ayamonte e Isla Cristina | fuente Google Earth 2018. Diseño de la vista Juan A. Márquez

frambuesas y extensas playas para el disfrute del turismo. También la industria se aloja, de forma intensa, en los términos municipales de Huelva y Palos de la Frontera. Completa la dotación, paisajes anclados a los sistemas portuarios, ya sean activos, como el de Huelva, puerto del Estado, y los puertos menores de Ayamonte, Isla Cristina y Lepe, a los que se unen los deportivos de Mazagón, Isla Canela, El Rompido o Punta Umbría. Pero también los puertos perdidos de Moguer, San Juan del Puerto, Palos de la Frontera... o San Miguel Arca del Buey encierran intensas señas de identidad.

La comarca es un espacio muy complejo. Examinando algunos indicadores sensibles de su territorio, se observa que, en apenas el $14 \%$ de la superficie provincial, se concentra el $62 \%$ de la población, el $24 \%$ de los núcleos poblados y $66 \%$ de los inmigrantes. Con una densidad de 231,74 habitantes por kilómetro cuadrado, supera con mucho la media provincial de sólo 51,23. Con todo, la comarca de Huelva y la costa occidental presenta una demografía muy activa, pues frente a la edad media de la provincia de 41,1 años, la 


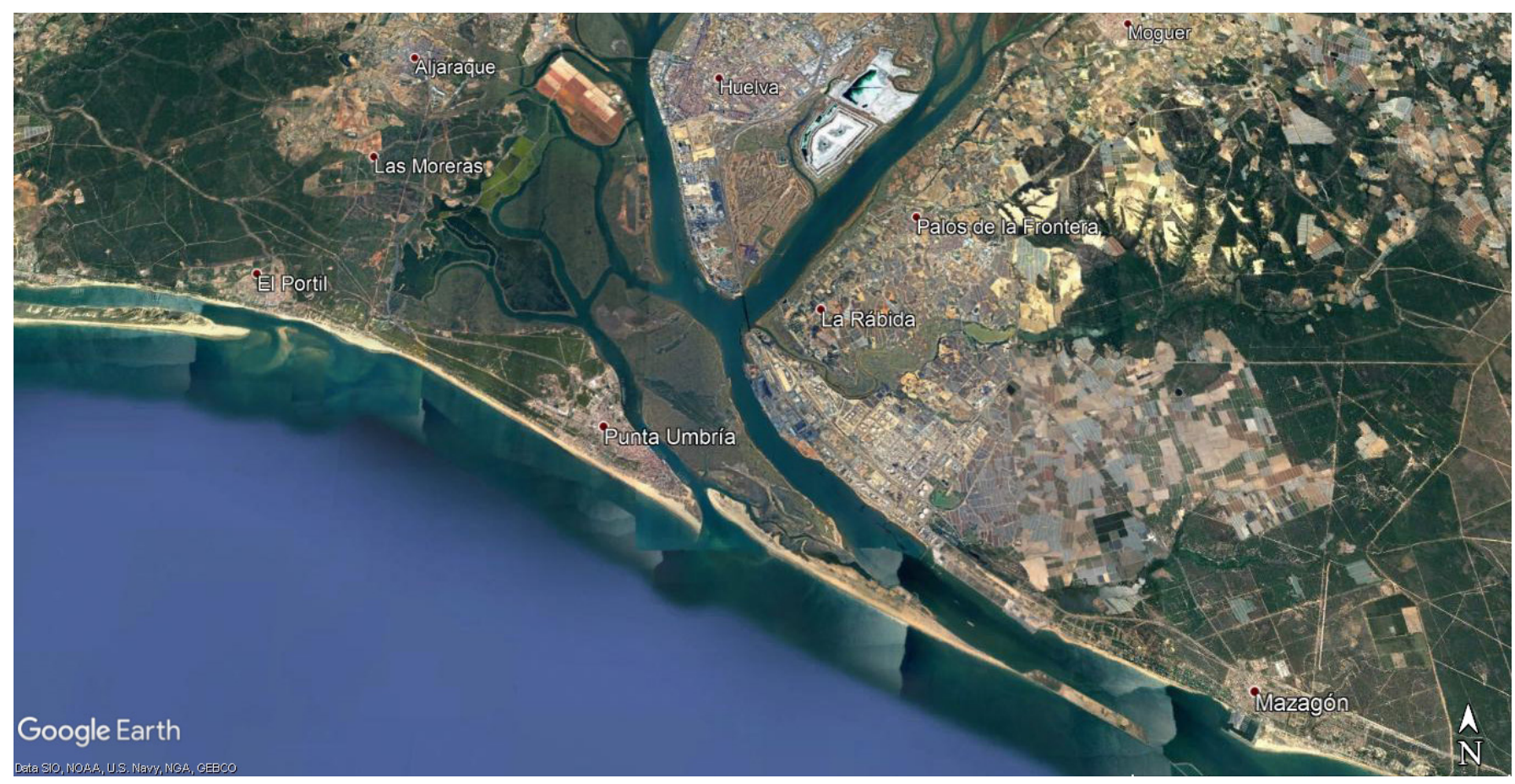

Vista general de Aljaraque, Punta Umbría, Huelva, Palos de la Frontera y Moguer | fuente Google Earth 2018. Diseño de la vista Juan A. Márquez

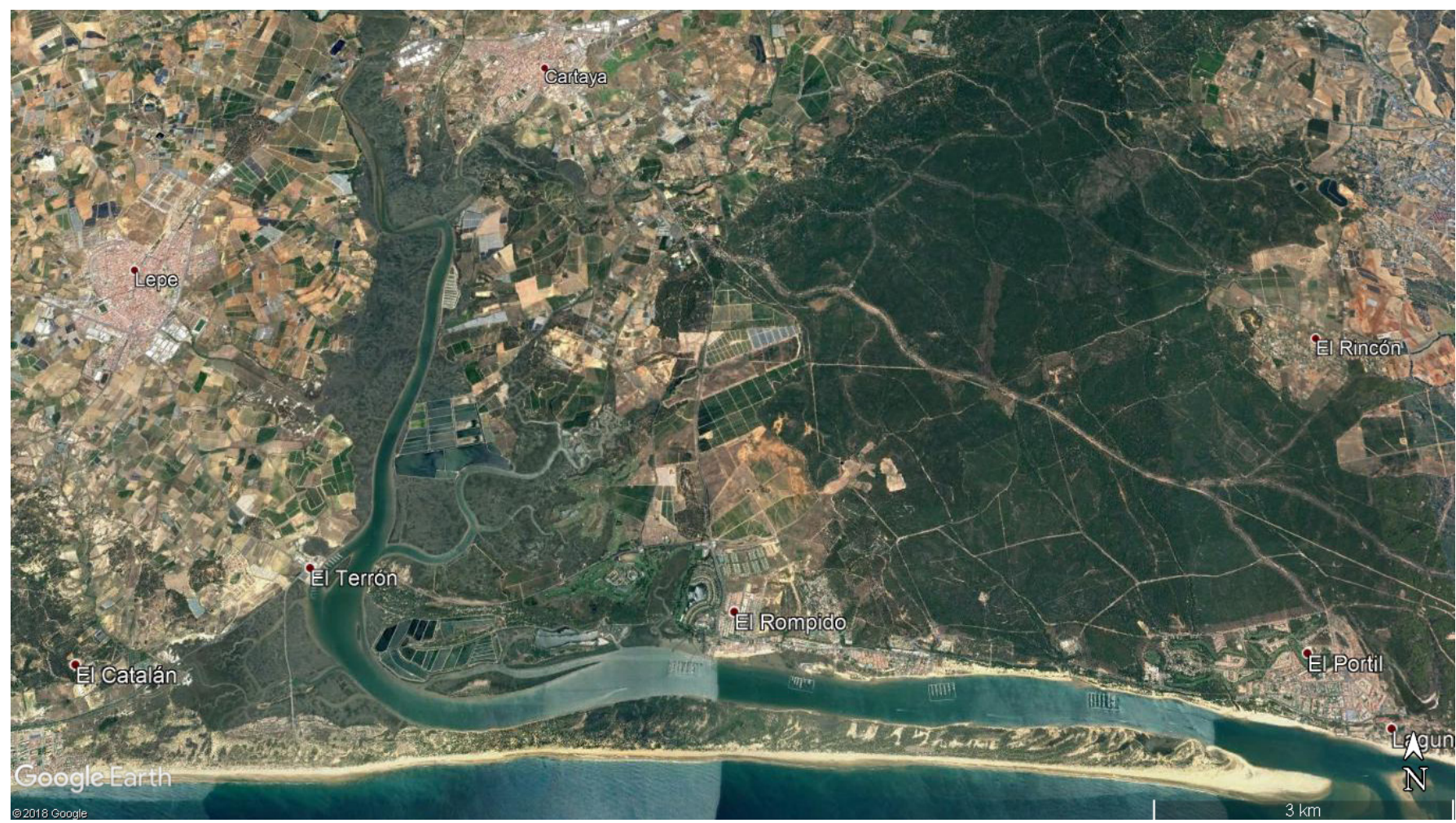

Vista general de Cartaya y Lepe | fuente Google Earth 2018. Diseño de la vista Juan A. Márquez 


\begin{tabular}{|c|c|c|c|c|c|c|c|c|c|}
\hline Municipios & $\mathrm{km}^{2}$ & $\% \mathbf{k m}^{2}$ & $\begin{array}{c}\text { Población } \\
\text { en } 1900\end{array}$ & $\begin{array}{c}\text { Población } \\
\text { en } 2017\end{array}$ & $\begin{array}{c}\text { \% Población } \\
\text { en } 2017\end{array}$ & $\begin{array}{l}\text { Edad media } \\
\text { en } 2017\end{array}$ & Inmigrantes & $\begin{array}{c}\text { N. }{ }^{\circ} \text { núcleos } \\
\text { poblados }\end{array}$ & $\begin{array}{c}\% \text { N. }{ }^{\circ} \text { de núcleos } \\
\text { poblados }\end{array}$ \\
\hline Ayamonte & 141,3 & 10,13 & 7.530 & 20.714 & 6,41 & 41,5 & 761 & 7 & 14,00 \\
\hline Isla Cristina & 49,4 & 3,54 & 5.969 & 21.175 & 6,55 & 39,2 & 660 & 9 & 18,00 \\
\hline Lepe & 127,9 & 9,17 & 5.125 & 26.931 & 8,34 & 37,7 & 972 & 6 & 12,00 \\
\hline Cartaya & 225,3 & 16,16 & 5.552 & 19.193 & 5,94 & 37,9 & 884 & 3 & 6,00 \\
\hline Aljaraque & 33,8 & 2,42 & 1.808 & 20.836 & 6,45 & 37,1 & 794 & 4 & 8,00 \\
\hline Gibraleón & 328,3 & 23,55 & 4.861 & 12.570 & 3,89 & 40,7 & 383 & 5 & 10,00 \\
\hline Huelva & 151,3 & 10,85 & 21.359 & 145.115 & 44,92 & 41,8 & 3.541 & 1 & 2,00 \\
\hline $\begin{array}{l}\text { San Juan } \\
\text { del Puerto }\end{array}$ & 45,3 & 3,25 & 3.541 & 9.116 & 2,82 & 37,7 & 370 & 4 & 8,00 \\
\hline Moguer & 203,5 & 14,60 & 8.455 & 21.514 & 6,66 & 38,2 & 1.049 & 4 & 8,00 \\
\hline $\begin{array}{l}\text { Palos de la } \\
\text { Frontera }\end{array}$ & 49,3 & 3,54 & 1.621 & 10.885 & 3,37 & 36,9 & 464 & 4 & 8,00 \\
\hline $\begin{array}{l}\text { Punta } \\
\text { Umbría }\end{array}$ & 38,8 & 2,78 & 6.606 & 15.038 & 4,65 & 41,4 & 602 & 3 & 6,00 \\
\hline $\begin{array}{l}\text { Total } \\
\text { comarca }\end{array}$ & $1.394,2$ & 100,00 & 72.427 & 323.087 & 100,00 & & 10.480 & 50 & 100,00 \\
\hline $\begin{array}{l}\text { Provincia } \\
\text { Huelva }\end{array}$ & $10.128,5$ & 13,77 & 462.579 & 518.930 & 62,26 & 41,1 & 15.665 & 209 & 23,92 \\
\hline
\end{tabular}

Perfil de indicadores sensibles en la comarca Huelva y costa occidental | fuente Instituto de Estadística y Cartografía de Andalucía, 2018. Elaboración Juan A. Márquez

mayor parte de sus municipios son más jóvenes. En San Juan del Puerto la edad media es de 36,9 años, en Aljaraque $37,1 \ldots$ o en Palos de la Frontera 36,9. Como ejemplo, este último caso significa que la población es cerca de 5 años más joven que la media provincial, con lo que ello puede repercutir en el sistema sanitario, educativo o económico.

\section{LOS DETERMINANTES NATURALES}

Aunque gran parte de la provincia de Huelva tiene como muro materiales paleozoicos, sobre el que se han depositado formaciones mesozoicas, terciarias y cuaternarias, el litoral de Huelva se asienta sobre un sustrato terciario, donde los procesos de subducción y diferentes modelados fluviales y marinos han hecho desaparecer todo vestigio de zócalo.

Por tanto, la base de la comarca es terciaria, sobre la que se han depositado, en un ambiente fluvio-marino, arenas, limos y arcillas. El conjunto territorial es muy reciente, hasta tal punto que se pueden observar cambios espectaculares provocados por la dinámica natural. La zona está compuesta por materiales terciarios, depositados en un ambiente marino. 


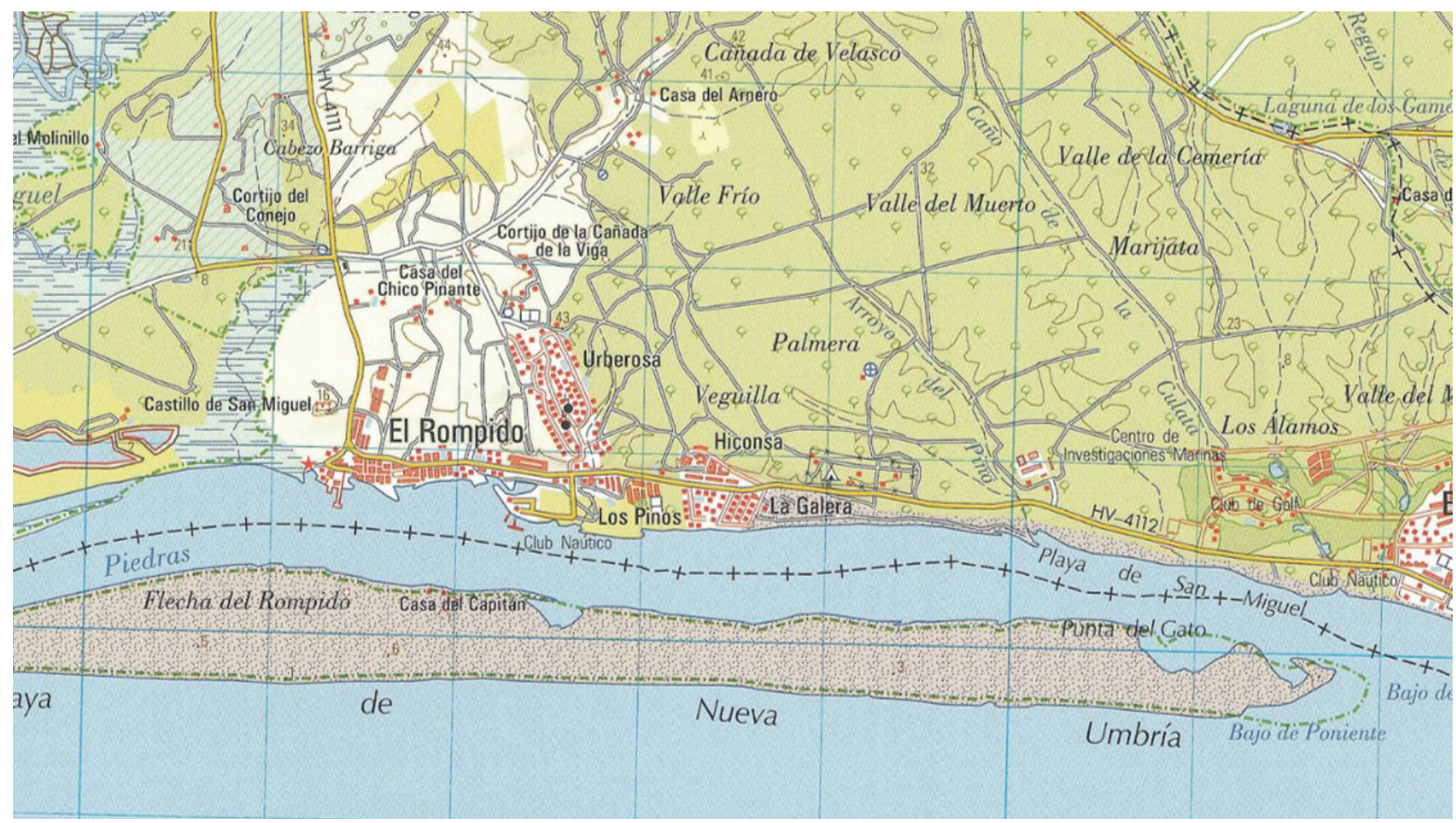

Desembocadura del río Piedras y flecha del Rompido. Cuadrícula UTM | fuente Instituto de Estadística y Cartografía de Andalucía

El retroceso del mar, a partir del Plioceno, dio lugar a un ambiente lagunar y al encajamiento de la red fluvial que aisló cerros testigos. En el Holoceno los ríos Tinto y Odiel constituyeron una bahía abierta, en la cual depositaron sedimentos que dieron lugar a barras e islotes de arenas y lodo. La acumulación de materiales a lo largo de los últimos millones de años y su distribución por las corrientes de marea han originado una compleja morfología de islas, marismas, barras de arena e islotes.

Así, la zona se estructura en franjas disimétricas que tienen su origen más moderno en las gravas, arenas y arcillas. Hacia el norte aparecen las tierras más antiguas, compuestas por limos amarillos y margas del Mioceno Superior, incluso al norte del término de Ayamonte se enlaza con suelos primarios y ya es Andévalo. Mientras tanto, hacia el sur, sureste y oeste, las tierras se conectan, sin solución de continuidad, con gravas, arenas, limos y arcillas de las marismas holocenas. Actualmente existe una subsidencia detectada en una línea de costa pliopleistocena, localizada a unos 30 kilómetros de la actual y a una profundidad de 50 metros (IGME, 1975).

En este contexto físico, la vida se vio favorecida por la disposición de las tierras y su apertura al océano Atlántico. Éste le brinda a la comarca un clima suave de tipo mediterráneo oceánico, que tiene como media anual los $18^{\circ} \mathrm{C}$. 


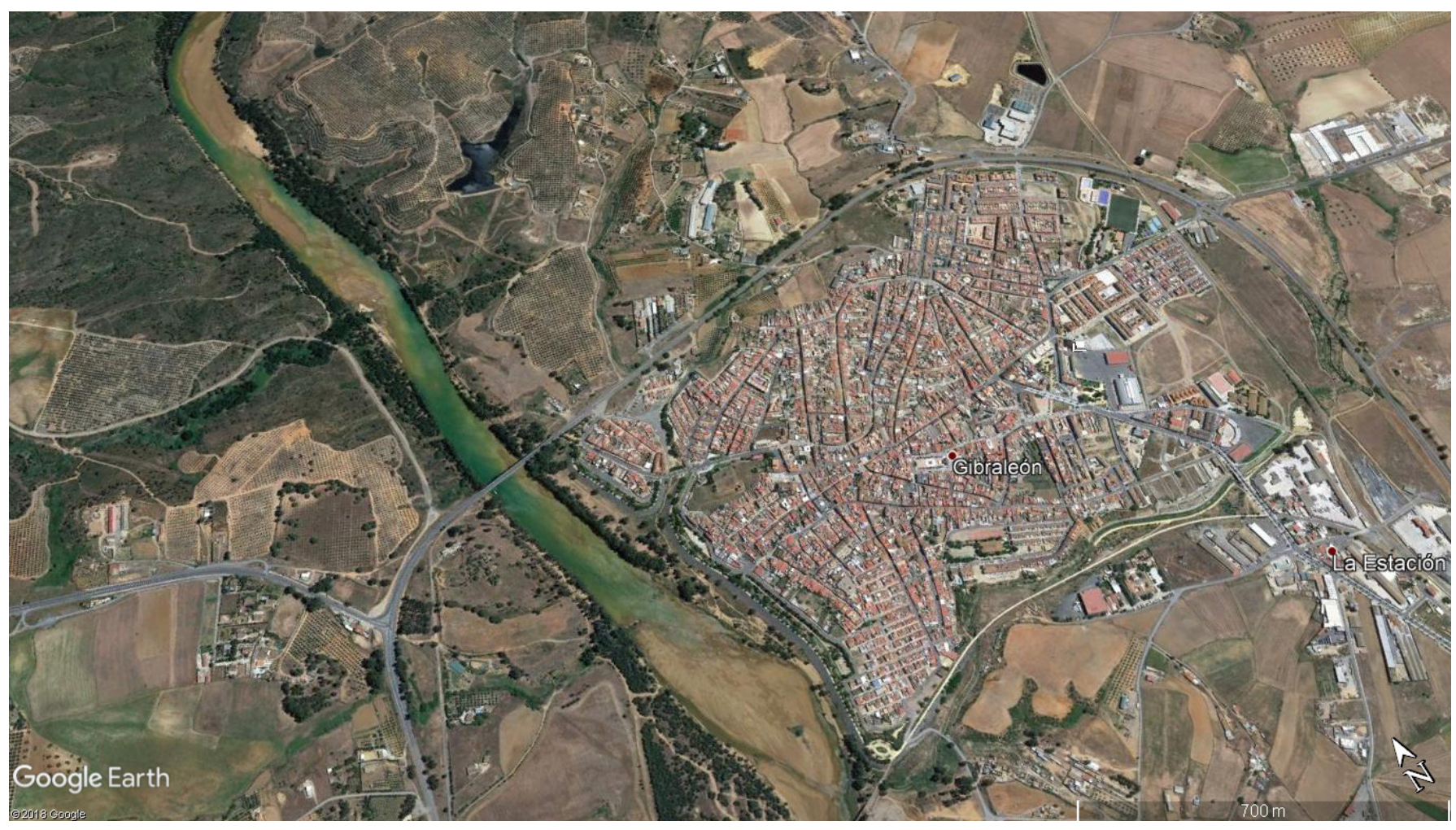

Gibraleón. Transita entre la nueva agricultura y los campos de olivares y almendros | fuente Google

La lluvia es moderada, recogiéndose una precipitación media anual en torno Earth 2018. Diseño de la vista Juan A. Márquez a los $500 \mathrm{~mm}$. Pero la verdadera singularidad del clima de la comarca está en las horas de sol, cerca de 3.000 anuales. La radiación y el calor, paliado por las brisas del mar, conforman soberbios ecosistemas de confort para el hombre y numerosas plantas cultivadas.

\section{LA FRONTERA URBANA Y EL NERVIO ECONÓMICO}

Dunas, marismas y manto eólico constituyeron una frontera para el poblamiento, pero también el espacio que nutre su expansión actual. Históricamente los núcleos urbanos estuvieron agazapados al interior, defendidos en promontorios y áreas miocénicas, calizas-limosas que sustentaban la trilogía mediterránea, trigo, vid y olivo, cultivos imprescindibles en el antiguo modelo alimentario.

Por mucho tiempo, la ciudad primada actual, Huelva, fue una modesta urbe y puerto de mar, emplazado sobre el estuario de los ríos Tinto y Odiel. La ciudad se confinaba sobre cabezos, que no eran sino colinas de 45 a 60 metros, fáciles de defender, frente a una zona llana e insalubre de marismas. Controlando las zonas de cumbres y llanuras, el antiguo castillo de Huelva 
fue símbolo de una enconada lucha contra una piratería que apenas la dejaba sobrevivir. Cercenado este mal, en el siglo XVIII, la ciudad empieza a descender y ocupar los caminos que llevan al puerto, apareciendo un núcleo bastante consolidado, en gran parte destruido por el terremoto de Lisboa de 1755. A partir de 1833 , se produjo la primera expansión urbana de importancia, como consecuencia de su nombramiento como capital. Después, a partir de 1871, una febril exportación de minerales a Europa impactó la trama urbana. Esta expansión, inducida por "la colonización inglesa", atrajo proletarios de otras provincias andaluzas, e incluso de Badajoz, Portugal y Galicia. En 1923, se diseñó el sector de mayor originalidad: el barrio obrero Reina Victoria, compuesto por 90 villas de una o dos plantas con un pequeño jardín.

Durante el siglo XX, Huelva incrementó su número de habitantes. La ciudad, con el $45 \%$ de la población de la comarca, sufre una metamorfosis que la extiende por cabezos y llanuras para alojar cerca de 150.000 habitantes. En la década de 1960 la ciudad tuvo el mayor crecimiento urbano de su historia.

Huelva en el siglo XIX. Una comunidad ligada a las marismas | fuente COELLO, 1848-1870. Coloreado de la vista Juan A. Márquez

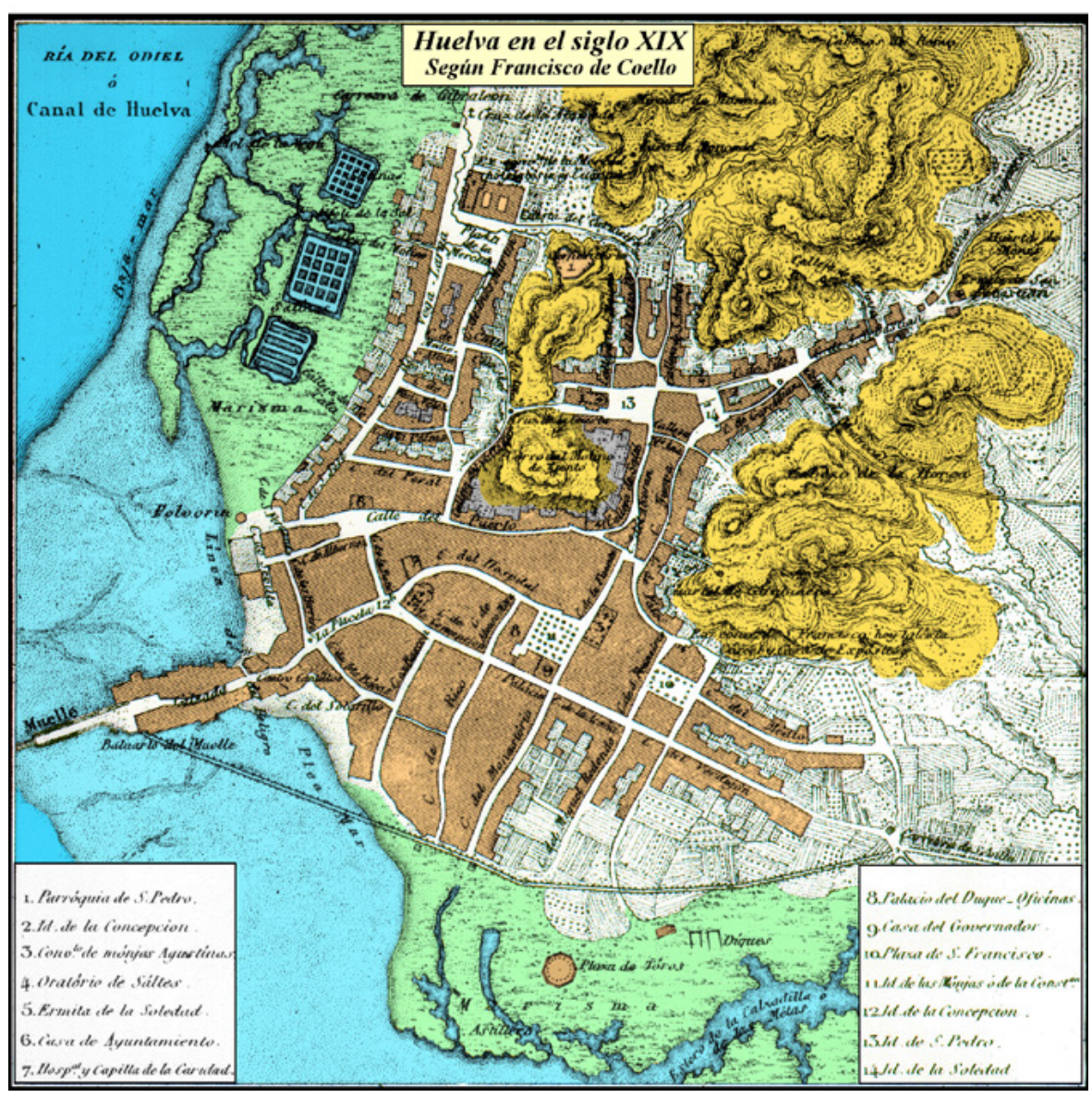




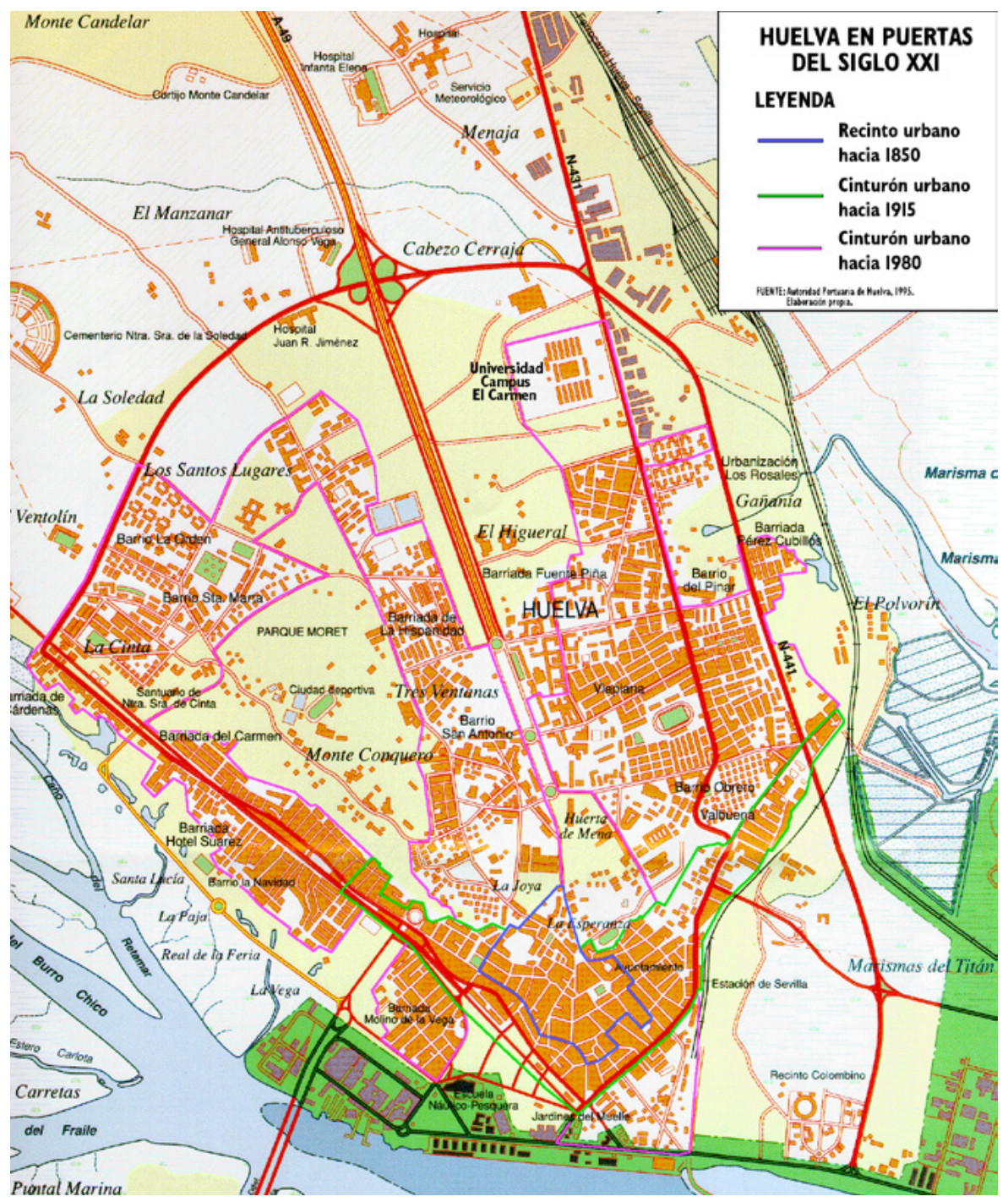

Huelva a las puertas del Siglo XXI | fuente MÁRQUEZ DOMÍNGUEZ, 1995-1997

En 1964 se delimitó una zona para que se beneficiase de un polo de promoción industrial y en 1968 de un polo de desarrollo industrial. La llegada de inversiones y la demanda de empleo atrajo un elevado número de inmigrantes. En poco tiempo la ciudad llegó a duplicar su población.

A partir de entonces, el área industrial de Huelva se constituye en el motor económico del municipio. La industria se extiende por la margen izquierda del río Odiel, desde la avenida Federico Montenegro, hasta llegar a la Punta del Sebo, enlazando con el Nuevo Puerto, ya dentro del término municipal de Palos de la Frontera. La crisis iniciada a principios de la década de 1970 ralentizó el ritmo de crecimiento y de renovación de la ciudad. Pero, superado este periodo de inanición, la Expo1992 fue una excusa para abordar 
Arriba izquierda. Huelva. Santuario de la Cinta, patrona de los marineros | fuente Google Earth 2018. Diseño de la vista Juan A. Márquez

Arriba derecha. Huelva. Punta del Sebo, con la escultura a la Fe Descubridora de la escultora Gertrude Vanderbilt Whitney de 1928 | fuente Google Earth 2018. Diseño de la vista Juan A Márquez

Abajo izquierda. Palos de la Frontera. En la Rábida se encuentra una reproducción de las carabelas que iniciaron la aventura colombina | fuente Google Earth 2018. Diseño de la vista Juan A. Márquez

Abajo derecha. Los Arándanos en la Costa de Huelva apuestan por la agricultura ecológica | foto Juan A. Márquez serios problemas que venían acuciando a la vieja ciudad. En el siglo XXI hay grandes esfuerzos por sanear la marisma e integrar el tejido urbano en el puerto.

Mientras tanto, fuera de la ciudad primada, el espacio urbano quedó durante mucho tiempo anclado en una historia que no despegaba, con interesantes núcleos urbanos que no sufrieron el proceso tranformador de Huelva. Ayamonte seguía con la frontera, Isla Cristina con su pesca y la sal, Lepe y Cartaya con el mar y el campo, Aljaraque con Corrales como apéndice minero, Gibraleón centrado en sus campos y olivares, San Juan del Puerto en la Empresa Nacional de Celulosas, Moguer en su vino y Juan Ramón, Palos de la Frontera en su Rábida y la gesta colombina, y Punta Umbría en su estrenado nacimiento, recién separada de Cartaya.

Sin embargo, a partir de la década de 1980, los municipios citados sufren una verdadera eclosión, provocada por las actividades turísticas y agrícolas. Nuevos espacios emergen en lugares que sólo eran transitados, de tarde en tarde, por campesinos-jornaleros, pescadores o pastores.
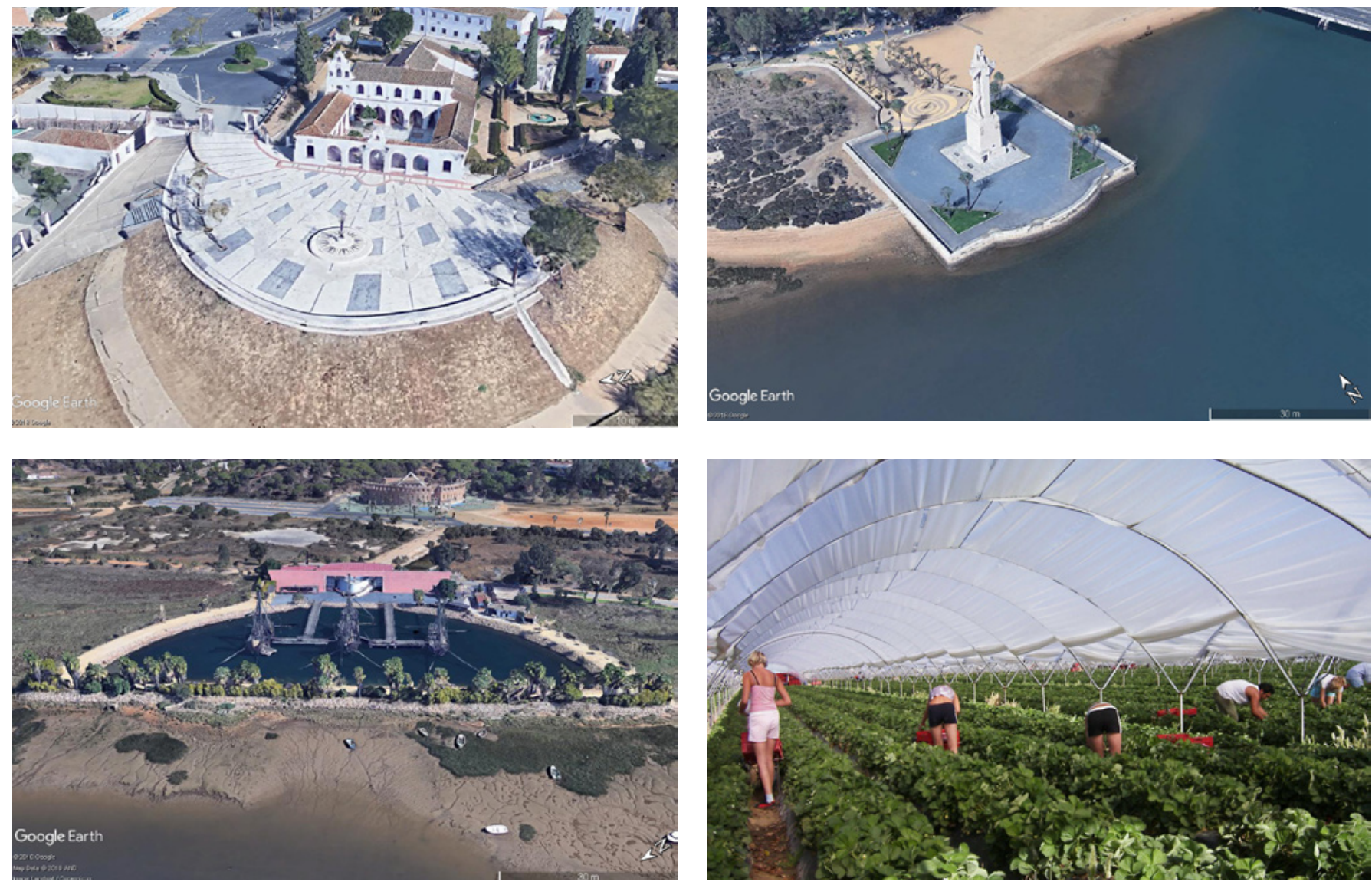


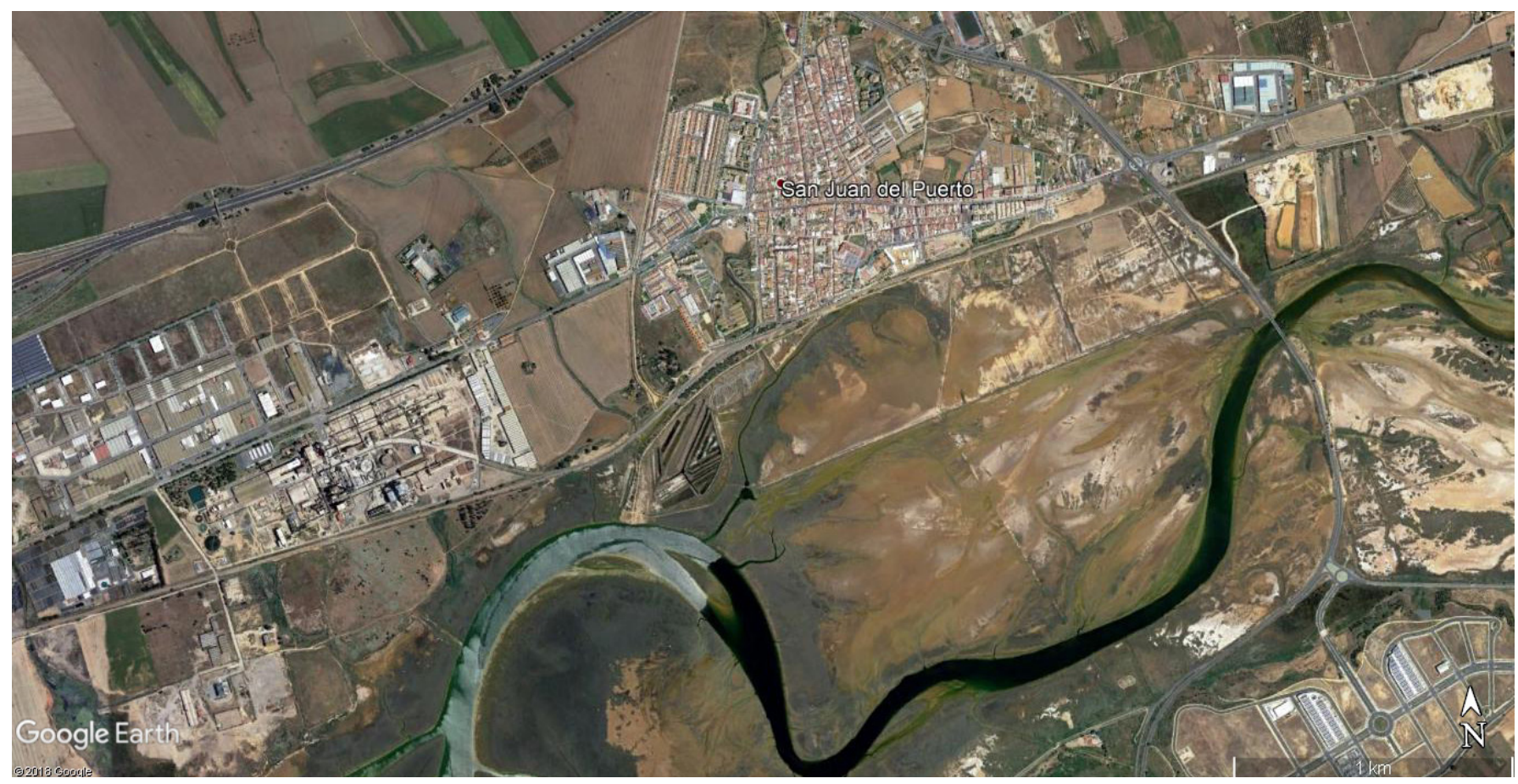

San Juan del Puerto. Entre la campiña y la marisma, perdió su identidad de puerto que hoy quiere recuperar | fuente Google Earth 2018.

El turismo y los campos de golf conquistaron el litoral con procesos especuDiseño de la vista Juan A. Márquez lativos y de segunda residencia. Estos procesos generaron fuertes transformaciones en Isla Canela y Costa Esuri en Ayamonte, en Islantilla, entre Lepe e Isla Cristina, en El Nuevo Portil, en Cartaya, en Bellavista y la Monacilla en Aljaraque, en Mazagón, entre Moguer y Palos, y en el crecimiento imparable de Punta Umbría, con un amplio equipamiento hotelero. Este avance urbano-turístico se ve reforzado por un fuerte nervio económico de los campos de naranjos, fresas, frambuesas y arándanos, que compiten, de forma muy exitosa, en el comercio internacional y se insertan entre los ruedos agrícolas tradicionales y el litoral.

\section{LOS ESPACIOS NATURALES. LAS MARISMAS DEL ODIEL}

La Red de Espacios Naturales Protegidos de Andalucía presenta en la provincia de Huelva un extenso catálogo de riquezas paisajística, pero la comarca Huelva y la costa occidental destaca por la singularidad de sus marismas. Las marismas constituyen espacios anfibios, donde la biodiversidad presenta su máxima expresión. En la comarca existen muchos espacios naturales relacionados con la marisma y los cordones arenosos que marcan la lucha continua entre las aguas continentales y marinas. Esto dificulta el transporte de sedimentos, que se depositan a la entrada de los estuarios, del Guadiana, del Tinto-Odiel, del Carreras, del Piedras, y mantienen 


\begin{tabular}{lllcc}
\hline Denominación & Protección & Municipios & ha & $\%$ ha \\
\hline Enebrales de Punta Umbría & Protección Integral & Punta Umbría & 55 & 0,41 \\
\hline Flecha del Rompido & Protección Integral & Lepe & 390 & 2,89 \\
\hline Lagunas Abalorio & Húmedas bien conservadas & Almonte, Moguer, Lucena del Puerto & 1.888 & 13,98 \\
\hline Marismas del Burro & Húmedas bien conservadas & Punta Umbría, Aljaraque, Huelva y Gibraleón & 597 & 4,42 \\
\hline Isla de Enmedio & Húmedas bien conservadas & Punta Umbría, Aljaraque, Huelva y Gibraleón & 480 & 3,55 \\
\hline Laguna del Portil & Húmedas bien conservadas & Punta Umbría & 60 & 0,44 \\
\hline Laguna de las Madres & Compatible con otros usos & Moguer & 100 & 0,74 \\
\hline Estero Domingo Rubio & Compatible con otros usos & Palos de la Frontera, Moguer & 340 & 2,52 \\
\hline Laguna de Palos & Compatible con otros usos & Palos de la Frontera & 65 & 0,48 \\
\hline Marismas del Piedras & Marismas transformadas & Lepe, Cartaya & 1.950 & 14,43 \\
\hline Del Guadiana y Carreras & Marismas transformadas & Ayamonte, Isla Cristina & 1.870 & 13,84 \\
\hline Marismas del Odiel & Marismas transformadas & Punta Umbría, Aljaraque, Huelva y Gibraleón & 5.714 & 42,30 \\
\hline Total & & & 13.509 & 100,00
\end{tabular}

Espacios naturales de interés en la comarca. Marismas, lagunas y spits | fuente Plan Especial de Protección del Medio Físico y catálogo de la provincia de Huelva (2007). Elaboración Juan A. Márquez las marismas. No obstante, las marismas no presentan un perfil homogéneo y aparecen dispersas en las desembocaduras de ríos, bordeando cauces anastomosados por un laberinto de meandros, que el hombre llenó de molinos de marea y de depósitos de sal. Algunas marismas fueron destruidas, como las del río Tinto, que soportaron durante decenios, frente a la ciudad de Huelva, los depósitos de fosfoyesos. Por su dilatada extensión y ecosistemas, destaca el parque natural Marismas del Odiel, que se extiende por más de 5.000 hectáreas y discurre entre los términos municipales de Punta Umbría, Aljaraque, Huelva y Gibraleón y que, paradójicamente, han sido marismas intensamente manejadas. Las marismas del Odiel "representan el más importante complejo de marismas de la península y uno de los más productivos de Europa" (RUBIO GARCÍA, 1991: 9). En 1983 fue reconocido por la Unesco, que lo declaró Reserva de la Biosfera. Al año siguiente, la Junta de Andalucía lo catalogó como paraje natural, con las reservas naturales de Isla de Enmedio y la Marisma del Burro. En las marismas, islas y esteros se desarrolla una importante biomasa que, debido a las suaves temperaturas, experimentan un crecimiento continuo. En los caños y esteros se han contabilizado más de 200 especies de aves, donde, además, viven gran cantidad de peces, moluscos y crustáceos. En la eclosión de la vida tiene un papel importante la existencia de salinas. En Marismas del Odiel fueron transformadas más de 1.000 hectáreas para la producción de sal. Efectivamente, sobre las Islas de Bacuta, La Liebre y los esteros de Cajabias, la empresa Energía e Industrias Aragonesas S. A. estuvo produciendo sal y cloro. Sin embargo, el cambio del cloro por oxígeno en el blanqueamiento del papel dejó prácticamente abandonadas las inmensas salinas que fueron colonizadas por el flamenco rosa. 


\section{BIBLIOGRAFÍA Y FUENTES DOCUMENTALES}

- BARCO Y GASCA, A. J. (1971) Disertación histórico geográfica, sobre reducir la antigua onuba a la villa de Huelva (Reproducción facsímil de la edición de Sevilla de 1755). Huelva: Diputación de Huelva, 1971

- BLÁZQUEZ, J. M. (1993) El enigma de Tarteso en los escritores antiguos y en la investigación moderna. En BLÁZQUEZ MARTÍNEZ, J. M.; ALVAR, J. (coord.) LoS enigmas de Tartesos. Madrid: Cátedra, 1993, pp. 11-30

- BODEVILLE, J. R. (1972) Aménagement du territoire et polarisation. Paris: MTGenin, 1972

- CANO GARCíA, G. (1992) La provincia de Huelva: un proceso de territorialización. Huelva en su historia, n. ${ }^{\circ} 4$, 1992, pp. $17-34$

- COELLO, F. (1848-1870) Atlas de España y sus posesiones de Ultramar (1848-1870). Madrid : [s.n.], 18481870

- FOURneAu, F. (1983) La provincia de Huelva y los problemas de desarrollo regional. Madrid: Consejo Superior de Investigaciones Cientificas, 1983 (Colección Instituto de Estudios Onubenses)

- GÓMEZ, F.; CAMPOS CARRASCO, J. M.; CASTIÑEIRA SÁNCHEZ, J.; GARCÍA, J. M.; BORJA BARRERA, F. (1994) Territorio y ocupación de la Tierra Llana de Huelva. El poblamiento de la Edad del Bronce. En CAMPOS CARRASCO, J. M.; PÉREZ MACÍAS, J. A.; GÓMEZ, F. (coord.) Arqueología en el entorno del Bajo Guadiana: actas del Encuentro Internacional de Arqueología del suroeste [(celebrado en) Huelva y Niebla, 25 a 27 de febrero de 1993]. Huelva: Universidad, 1994, pp. 329-350

- GONZÁLEZ CRUZ, D. (1995) La tierra y los hombres en la Huelva del Antiguo Régimen. En REY DE LAS PEÑAS, R. (coord.) El tiempo y las fuentes de su memoria (Tomo II). Huelva: Diputación Provincial de Huelva, 1995

- GONZALO Y TARÍN, J. (1886) Descripción física, geológica y minera de la provincia de Huelva. Madrid: Imprenta y Fundición de Manuel Tello, 1886-1887 (Serie Memorias de la Comisión del Mapa Geológico de España)

- JURAdO ALMONTE, J. M. (2014) Turismo de frontera en la provincia de Huelva. En ANTONIO CAMPESINO FERNÁNDEZ, J.; JURADO ALMONTE, J. M. (dir.) Turismo de frontera III. Productos turísticos de la Raya Ibérica. Huelva: Universidad de Huelva, 2014, pp. 113-134

- IGME (1975) Huelva-Los Caños. Madrid: Instituto Geológico y Minero de España (IGME), Ministerio de Industria, 1975 (Colección Mapa Geológico de España)

- MADOZ, P. (1806-1870) (1985) Diccionario geográficoestadístico-histórico España y sus posesiones de Ultramar. Huelva: Diputación de Huelva, Servicio de Publicaciones, 1985 (edición facsímil)
- MÁRQUEZ DOMíngUEZ, J. A. (coord.) (1995-1997) Los pueblos de Huelva. 4 Tomos. Madrid: Editorial Mediterráneo, 1995-1997

- MÁRQUEZ DOMínGUEZ, J. A. (2008) (dir.) Atlas del Suratlántico peninsular: un análisis de la estructura territorial y del potencial productivo. Huelva: Universidad de Huelva, Servicio de Publicaciones, 2008

- MÁRQUEZ DOMÍNGUEZ, J. A. (2012) Desactivación de la frontera. Desvertebración de la Raya lusoandaluza $y$ desenfoque de las políticas territoriales de desarrollo. Saarbrüken (Alemania): Editorial Académica Española, 2012

- MÁRQUEZ DOMínGUEZ, J. A. (2016) Vertebración internacional de los campos de fresas españoles. En VERA REBOLLO J. F.; OLCINA CANTOS, J.; HERNÁNDEZ HERNÁNDEZ, M. (coord.); MORALES GIL, A. (hom.) Paisaje, cultura territorial y vivencia de la geografía. Homenaje a Alfredo Morales Gil. Alicante: Universidad de Alicante, Instituto Interuniversitario de Geografía, 2016, pp. 605-628

- MEMORIA anual. Puerto de Huelva (2016). sl: Ministerio de Fomento, Autoridad Portuaria de Huelva

- MORA NEGRO Y GARROCHO, J. A. (DE) (1762) Huelva ilustrada : breve historia de la Antigua, y Noble Villa de Huelva. Sevilla: en la Imprenta del Dr. Don Geronymo de Castilla, Impresor mayor de dicha Ciudad, 1762

- NúÑEZ ROLDÁN, F. (1987) En los confines del reino. Huelva y su tierra en el siglo XVIII. Sevilla: Servicio de Publicaciones de la Universidad, 1987

- PEÑA GUERRERO, M. A. (1995) La provincia de Huelva en los siglos XIX y XX. En REY DE LAS PEÑAS, R. (coord.) El tiempo y las fuentes de su memoria. Historia moderna y contemporánea de la provincia de Huelva. Volumen IV. Huelva: Diputación Provincial de Huelva, 1995, pp. 9-239

- RESOLUCIÓN de 14 de febrero de 2007, de la Dirección General de Urbanismo, por la que se dispone la publicación del Plan Especial de Protección del Medio Físico y Catálogo de Espacios y Bienes Protegidos de la provincia de Huelva. Boletín Oficial de la Junta de Andalucía, n. ${ }^{\circ} 66$, de 3 de abril de 2007

- RUBIO GARCíA, J. C. (coord.) (1991) Estudio de la gestión integrada de las marismas del Odiel. Sevilla: Agencia de Medio Ambiente, Comisión de las Comunidades Europeas, Dirección General IX 


\section{$\mathrm{PH} 96_{\text {bienes, paisajes e itinerarios }}$}

\section{Panorama actual de la arqueología urbana en Huelva}

Juan M. Campos Carrasco | Dpto. de Historia I de la Universidad de Huelva

URL de la contribución <www.iaph.es/revistaph/index.php/revistaph/issue/view/4290>

\section{RESUMEN}

En esta contribución ${ }^{1}$ se presenta un panorama general de la arqueología urbana en la ciudad portuaria de Huelva. Se analizan las diferentes etapas, marcadas por distintos intereses, metodologías y mecanismos de gestión, por las que han transcurrido las intervenciones arqueológicas en la ciudad desde el año 1966 hasta el presente, que ascienden a 324, para a partir de ahí realizar un balance de los resultados, analizar la situación actual y reflexionar sobre un proyecto de futuro que permita el rescate y la reconstrucción de la memoria histórica de la ciudad de Huelva. Proyecto que ha de desarrollarse en el marco de diálogo entre los ciudadanos, ávidos de conocer su pasado, los agentes de desarrollo inmobiliario, generadores de riqueza y progreso, la Universidad, garante de la investigación, y los poderes públicos, responsables de garantizar el futuro del pasado.

Palabras clave

Arqueología urbana | Onoba | Huelva | Patrimonio arqueológico | Tarteso | 


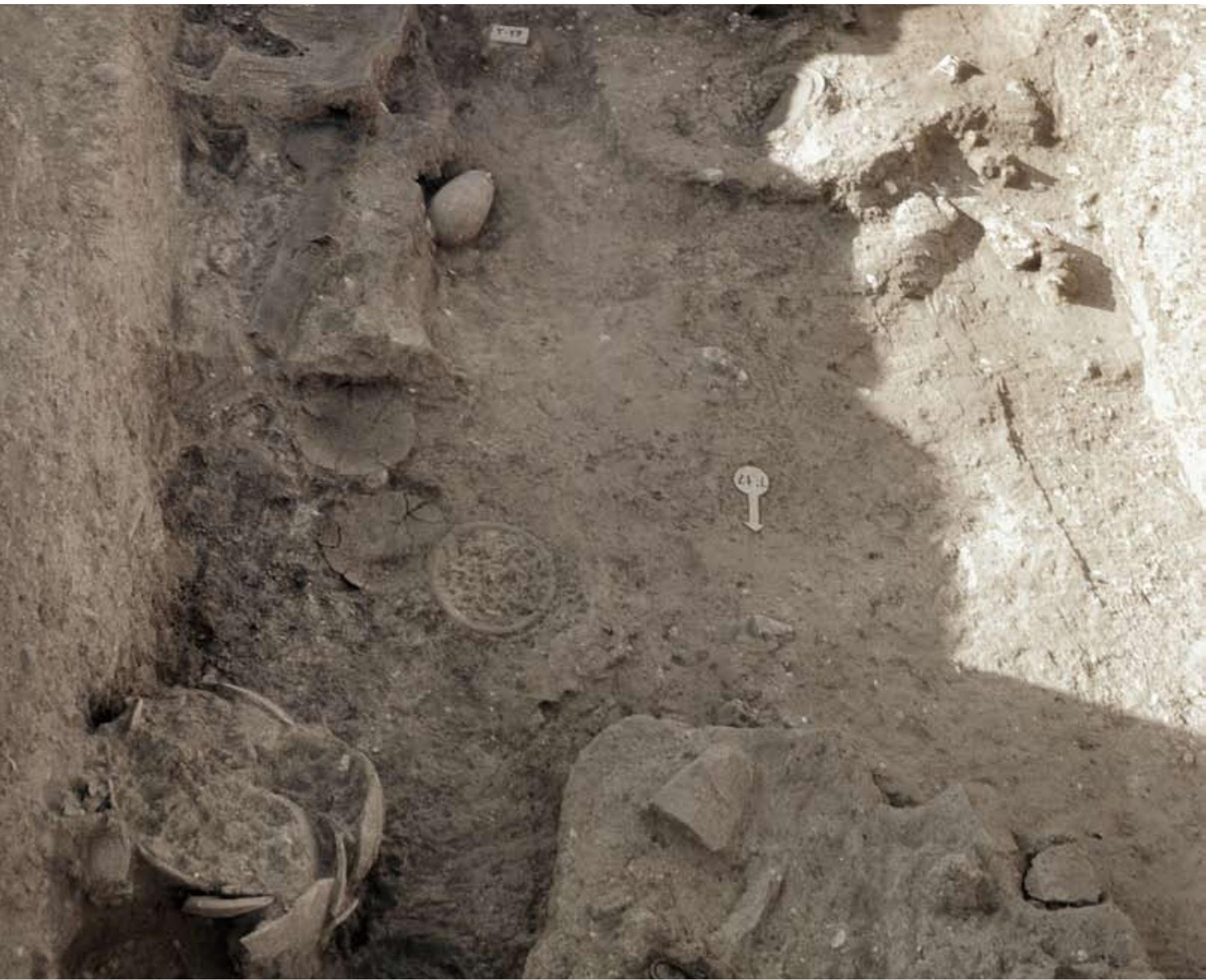

Excavación de la tumba 17 de La Joya | fuente LÓPEZ; GARCíA, 2010 


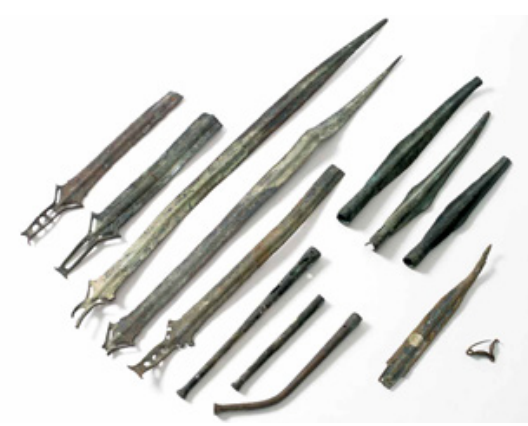

Bronces encontrados en la ría de Huelva | fuente TOSCANO; CAMPOS, 2018

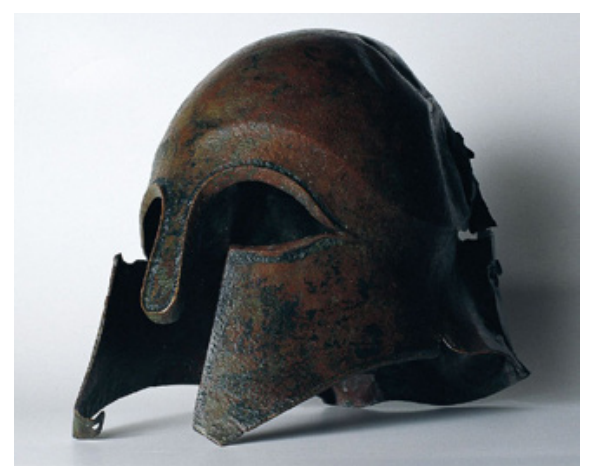

Casco corintio de la ría de Huelva | fuente ALMAGRO-GORBEA; CASADO; FONTES et ál., 2004

1

El presente trabajo se enmarca dentro de las actividades del Proyecto de Investigación de Excelencia del Plan Andaluz de Investigación Ciudades Romanas de la Bética. CORPVS VRBIVM BAETICARVM I (Ref. HUM 2062) y del proyecto del Plan Nacional de I+D De Atlántico al Tirreno ( $2^{\mathrm{a}}$ fase). Los puertos hispanos y su relación comercial con Ostia Antica (HAR2014-58326-P).

\section{INTRODUCCIÓN}

El descubrimiento en 1923 de un lote de bronces en el dragado de la ría de Huelva (ALMAGRO BASCH, 1940; 1957), al que años más tarde se unen un casco y un fragmento de aryballos corintios (ALBELDA; OBERMAIER, 1931; OLMOS ROMERA, 1988; ROUILLARD, 1978) despertaron la curiosidad de la comunidad científica, acrecentada por el descubrimiento en 1945 de una tumba en el cabezo de la Joya, cuya publicación casi veinte años después (ORTA GARCÍA; GARRIDO ROIZ, 1963) estableció una inmediata relación de Huelva con Tarteso, en un ambiente que volvía a ser propicio para la reanudación de la búsqueda de la legendaria ciudad, por los nuevos hallazgos que se estaban produciendo en el resto de Andalucía (MALUQUER DE MOTES, 1969).

Pero no será hasta mediados de los años 60 del pasado siglo cuando, de la mano de los profesores Juan Pedro Garrido y Elena M. ${ }^{\text {a }}$ Orta, comienzan las primeras intervenciones arqueológicas en la ciudad, en los cabezos de la Esperanza y La Joya. Desde entonces hasta hoy se han producido 324 intervenciones que hacen que el yacimiento de Huelva sea el más excavado de la provincia.

\section{LAS INTERVENCIONES EN LA CIUDAD}

El conjunto de intervenciones arqueológicas antes señalado puede considerarse muy desigual, según el momento de que se trate, pudiendo distinguirse varias etapas marcadas por diferentes intereses, metodologías y mecanismos de gestión que a continuación sintetizamos.

La primera etapa, caracterizada por la búsqueda de Tarteso, se desarrollará entre 1966 y 1971. Supone el comienzo de las primeras excavaciones en la ciudad realizadas por diversos equipos de la Universidad Complutense de Madrid. La importancia del hábitat protohistórico de Huelva, a partir de la publicación de la tumba orientalizante de La Joya (ORTA GARCíA; GARRIDO ROIZ, 1963), propició la búsqueda de otros enterramientos que correspondiesen a la misma u otras necrópolis, ubicadas en la ciudad. De esta forma, en la necrópolis de La Joya, en sucesivas campañas de verano, se excavaron varias tumbas en la superficie del cabezo cuyos ajuares las fecharon entre finales del siglo VII y comienzos del VI a. de C. (ORTA GARCÍA; GARRIDO ROIZ, 1963; GARRIDO ROIZ, 1970; GARRIDO ROIZ; ORTA GARCíA, 1978; 1989). El hábitat sincrónico a estas tumbas sería buscado inicialmente en los cabezos de La Esperanza (GARRIDO; ORTA, 1969; SCHUBART; GARRIDO ROIZ, 1967; BELÉN DEAMOS; FERNÁNDEZMIRANDA; GARRIDO ROIZ, 1978). En 1968, en unos trabajos de desmonte que se estaban realizando en el cabezo de San Pedro, aparecieron niveles 


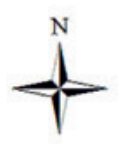

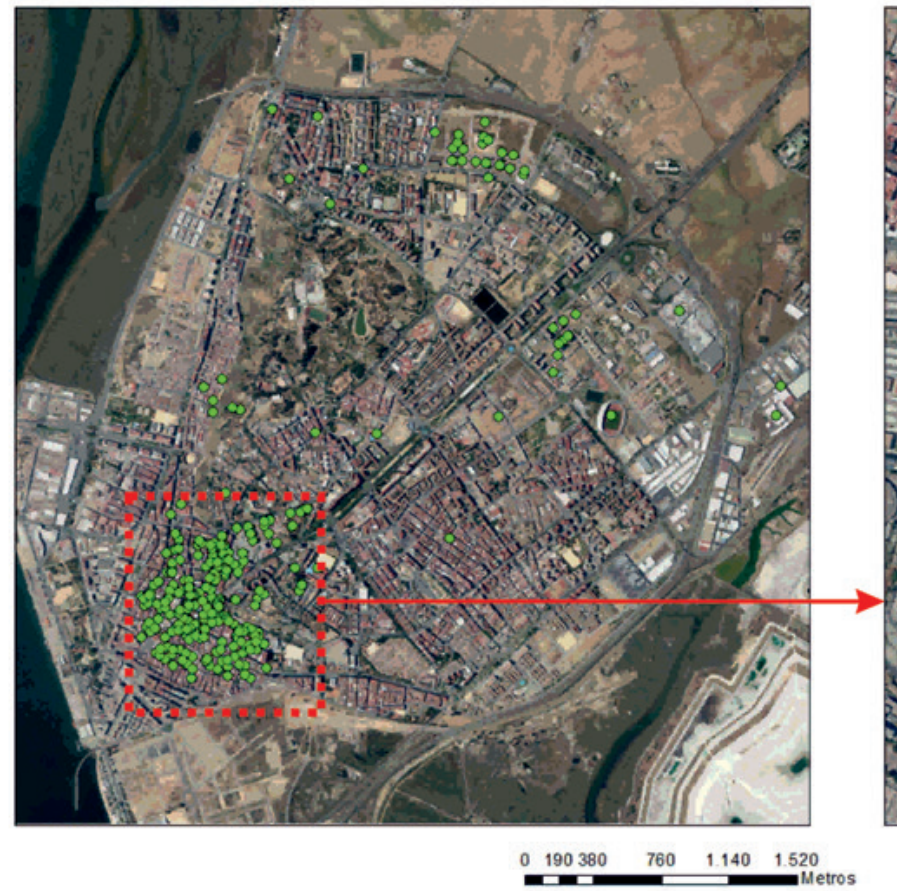

arqueológicos de amplia cronología estableciéndose una primera sistematización de la ocupación del lugar (BLÁZQUEZ MARTíNEZ; LUZÓN NOGUÉ; GÓMEZ et ál., 1970). Como resultado de todas estas intervenciones realizadas sobre los cabezos de la Joya y La Esperanza, que ascendieron a 10, se elabora una primera sistematización del poblamiento prerromano de Huelva, dividido en amplios períodos, desde el más antiguo, Huelva I, indígena aunque con escasas importaciones fenicias, hasta Huelva $\mathrm{VI}$, que significaba el comienzo de la romanización del hábitat situado en los cabezos (AMO Y DE LA HERA; BELÉN DEAMOS, 1981).

Entre 1972 y 1976 se identifica una segunda etapa, protagonizada por el Museo de Huelva, que pone al descubierto restos romanos de la Onoba romana (AMO Y DE LA HERA, 1976).

A partir de 1977 y hasta 1981 se desarrolla una tercera etapa caracterizada por la vuelta a la arqueología tartésica. El siguiente equipo que excavará en la cima de San Pedro (BLÁZQUEZ MARTíNEZ; RUIZ MATA; REMESAL RODRÍGUEZ et ál., 1979; RUIZ MATA; BLÁZQUEZ MARTÍNEZ; MARTÍN DE LA CRUZ, 1981) alcanzó unos resultados que con matizaciones pueden ser considerados todavía vigentes (RUIZ MATA, 1986; 1995). En el

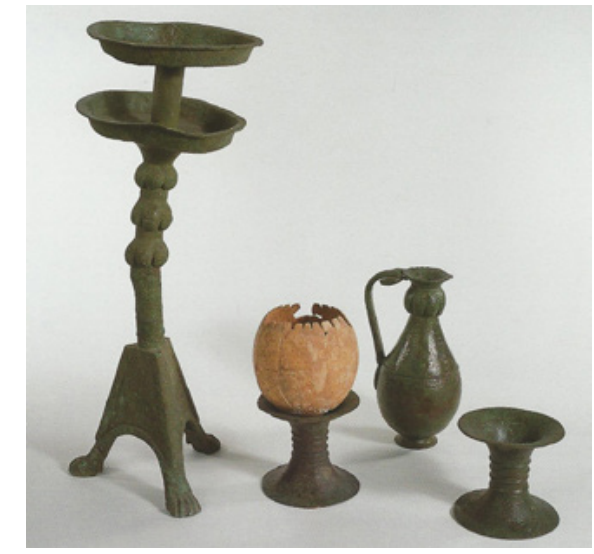

Ajuar de la tumba 17 de La Joya | fuente GARCíA ALFONSO, 2010 


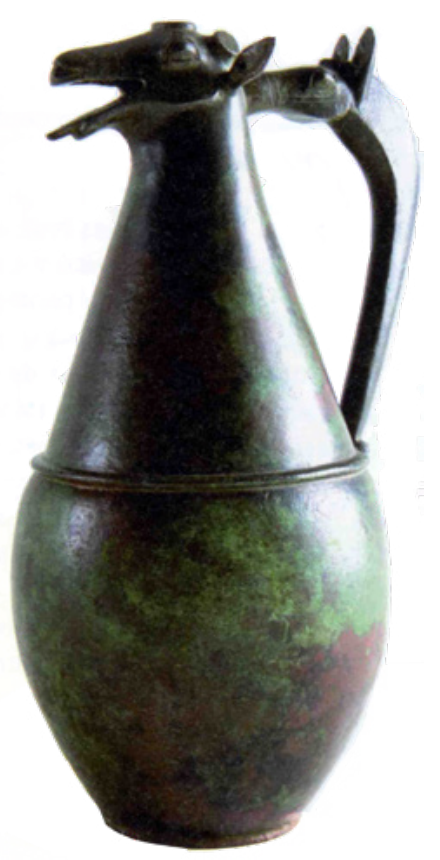

Ajuar de la tumba 18 de la Joya | fuente VALLEJO SÁNCHEZ, 2010

A la derecha, plano de los restos de la cetaria de Huelva | fuente AMO Y DE LA HERA, 1976
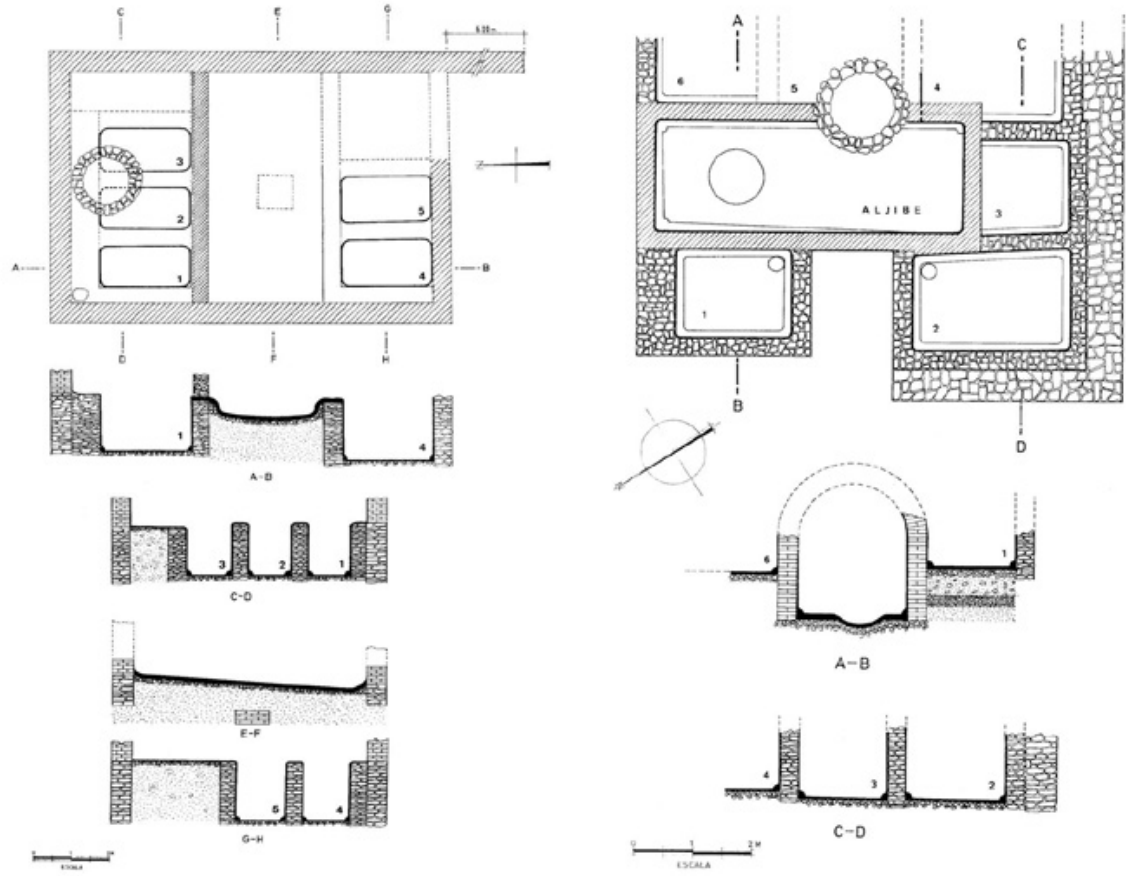

verano de 1980 se realizan algunos sondeos en el solar número 10 de la calle del Puerto. Como resultado, surgen diversos artículos donde se pone el énfasis en las cerámicas griegas arcaicas localizadas (OLMOS ROMERA; CABRERA BONET, 1980; OLMOS ROMERA, 1982; CABRERA BONET, 1986; FERNÁNDEZ JURADO; CABRERA BONET, 1987; GARRIDO ROIZ; ORTA GARCÍA, 1989), que suponen una novedad importante para retomar los planteamientos que se relacionaban con la presencia de los griegos en Tarteso, y que provocarán, en última instancia, que prácticamente se abandone la investigación del período romano y otros posteriores.

Durante casi toda la década de los 80 y 90 se desarrolla la cuarta etapa. Será el equipo de la Diputación Provincial de Huelva el que protagonice, salvo contadísimas excepciones, las excavaciones en la ciudad al amparo del modificado del artículo 104 del Plan General de Ordenación Urbana de 1980. Científicamente, en esta etapa continúa el interés preferencial por el mundo tartésico en detrimento del mundo romano, medieval y moderno. Queda, sin embargo, un número importante de publicaciones, tanto de carácter científico (FERNÁNDEZ JURADO, 1988-1989; FERNÁNDEZ JURADO; RUFETE TOMICO; GARCÍA SANZ, 1992) como divulgativo (FERNÁNDEZ JURADO; GARCÍA SANZ; RUFETE TOMICO, 1997; RUFETE TOMICO; GARCÍA SANZ, 1995), que constituyen un importantísimo corpus de información para el conocimiento de la arqueología onubense, en especial el periodo protohistórico. 
Finalmente, la etapa actual comienza a partir de 1999. La incoación del expediente de Declaración de la zona arqueológica de Huelva cambia radicalmente el panorama anteriormente descrito provocando una nueva política patrimonial para las excavaciones arqueológicas que se realizan en el casco antiguo de Huelva y que, entre otras cosas, conlleva un tratamiento diferente de otros periodos históricos. Una de las consecuencias más destacable ha sido la gran revitalización de la Onoba romana, cuyos restos materiales están viendo la luz de forma más intensa en los últimos años, permitiendo incluso las reconstrucciones virtuales de algunos de los espacios excavados, en especial la zona portuaria (CAMPOS CARRASCO, 2001-2002; 2011; VIDAL; CAMPOS, 2006; CAMPOS CARRASCO; BERMEJO MELÉNDEZ, 2017; DELGADO AGUILAR, 2016; BERMEJO MELÉNDEZ; CAMPOS CARRASCO; RODRÍGUEZ-VIDAL, 2017). Esta nueva realidad se cimenta en dos hechos fundamentales: el aumento del número de intervenciones, unas 220 desde entonces hasta hoy, y la incorporación a las intervenciones de la Universidad de Huelva y de empresas profesionales de arqueología.

Desde fines de 2016 hasta hoy, aunque interrumpido durante casi todo el año 2018, se ha desarrollado un Plan General de Investigación de la zona arqueológica de Huelva, como transición hacia un verdadero proyecto de arqueología urbana, gracias al protocolo firmado entre la Consejería de Cultura de la Junta de Andalucía y la Universidad de Huelva. La finalidad principal es la recuperación e integración de la información arqueológica derivada de las actividades arqueológicas desarrolladas en la ciudad, cuyos materiales se encuentran depositados en el Museo de Huelva. Paralelamente se están realizando diagnósticos de los diversos sectores que conforman la zona arqueológica. Finalmente se está actualizando la carta de riesgo mediante la incorporación en un SIG de toda la información que se va generando así como de las nuevas intervenciones que se producen en la ciudad (CAMPOS CARRASCO, 2016).

Es dentro de esta tendencia de apertura donde hay que valorar el avance producido en la investigación arqueológica de este yacimiento, y especialmente en lo que se refiere a su horizonte romano, carente hasta el momento de una interpretación conjunta de los distintos aspectos que lo integran.

\section{BALANCE DE LAS INTERVENCIONES}

La actividad arqueológica en la ciudad de Huelva, desde los inicios de las primeras intervenciones en 1966 hasta hoy, ofrece luces y sombras, pudiendo destacar las siguientes cuestiones:

Desde el punto de vista de la metodología aplicada, la primera cuestión a señalar, en consecuencia con lo anteriormente expuesto, es el hecho de que

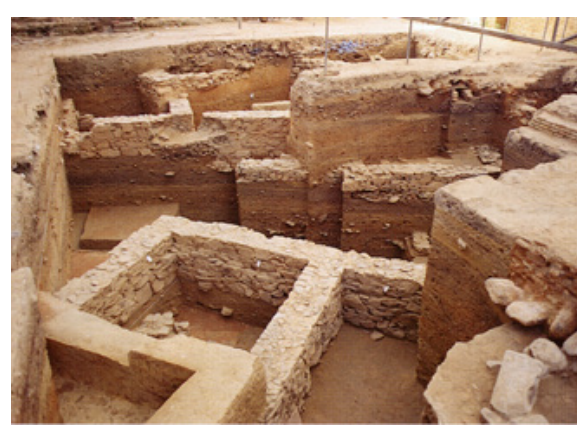

Restos protohistóricos hallados en la C/ Puerto, 12 | fuente RUFETE TOMICO; GARCÍA SANZ, 1995

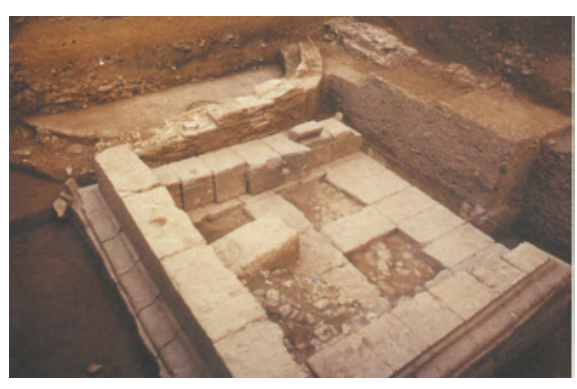

Basamento romano. Convento de las Agustinas | fuente FERNÁNDEZ JURADO; GARCÍA SANZ; RUFETE TOMICO, 1997 

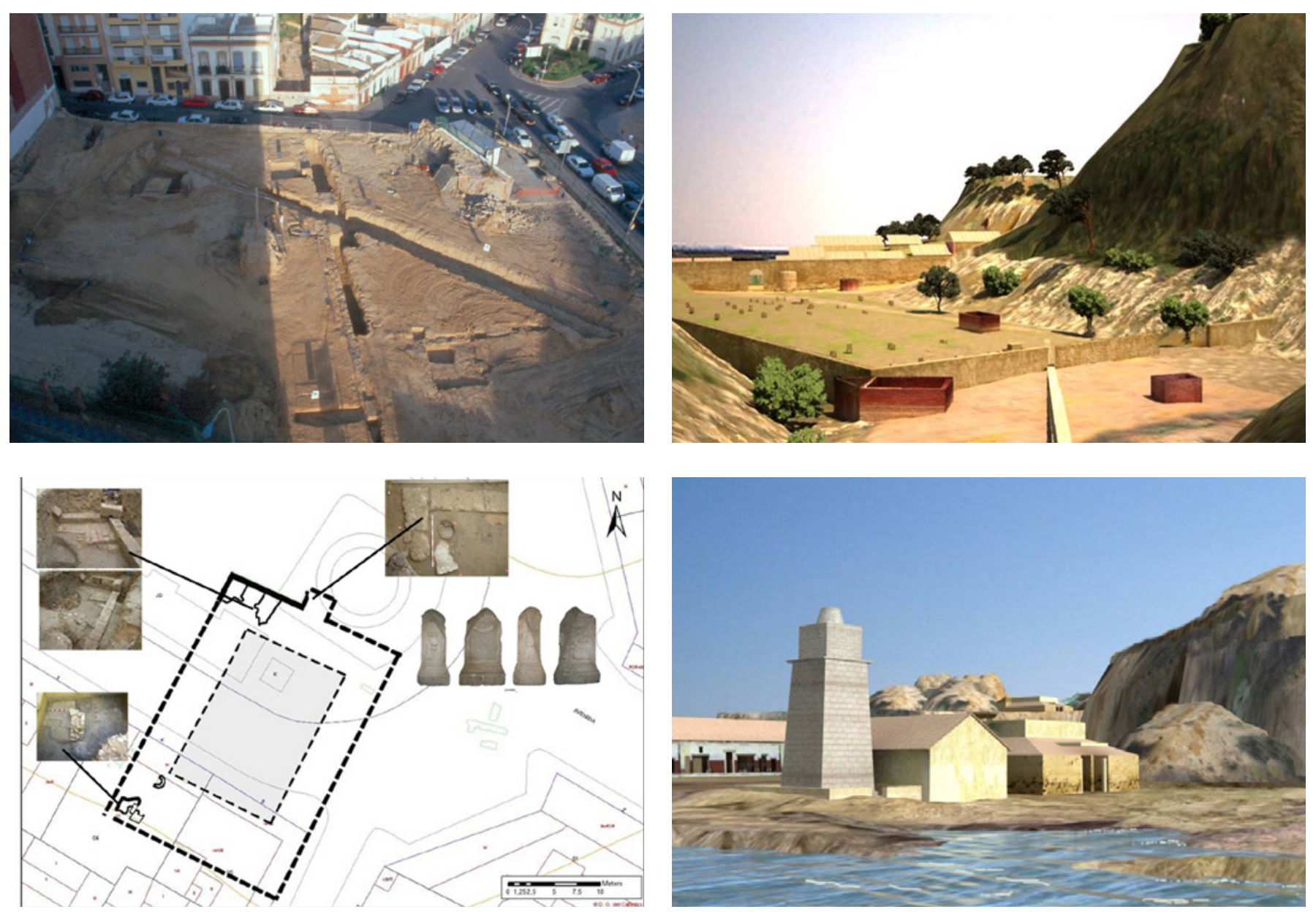

Arriba a la izquierda, necrópolis romana del Colegio Francés

Arriba a la derecha, reconstrucción infográfica de la necrópolis del Colegio Francés

Abajo a la izquierda, restitución del edificio romano de sillares de plaza de las Monjas

Abajo a la derecha, restitución infográfica de la zona portuaria y faro de Onoba | foto, esquema e infografías Grupo de Investigación Vrbanitas Arqueología y Patrimonio el conjunto de las intervenciones no ha estado presidido nunca por un verdadero proyecto de arqueología urbana, limitándose al concepto de intervenciones en medio urbano que difiere notablemente de aquél. La ausencia de un proyecto de ciudad ha impedido, hasta el momento, una síntesis del conjunto del poblamiento y su evolución desde los inicios de la ocupación del espacio, desde la prehistoria hasta la actualidad. Por otro lado, han sido muy diferentes los métodos de excavación puestos en práctica y los planteamientos científicos para la interpretación del registro arqueológico. Por último, y referido a los tiempos presentes, hay que señalar que el hecho de que las actuaciones sean realizadas por diferentes empresas de arqueología dificulta la incorporación de los datos a un proyecto general de investigación, basado en el concepto de arqueología urbana o, al menos, la fluidez de los mismos al banco de datos ya existente en la carta de riesgo, que debería estar siempre actualizado, si se quiere disponer de una herramienta útil tanto para la gestión del patrimonio arqueológico de la ciudad, como para su investigación histórico-arqueológica. El desarrollo del actual 
Plan General de Investigación vigente intenta paliar en parte los problemas señalados.

En cuanto a la orientación de las intervenciones, como ya se ha puesto de manifiesto, salvo el caso de las realizadas por el Museo Provincial a principios de los años 70, el interés de la investigación se centró casi con exclusividad en el mundo tartésico. Esta tendencia ha cambiado notablemente en la etapa que comenzó a fines de los años 90 dándose una mayor importancia a otros periodos históricos que ha contribuido a enriquecer de manera muy notable el conocimiento histórico de la Huelva romana, medieval y moderna.

En relación con lo anterior, el rendimiento científico ha estado muy determinado por esa orientación de forma que el nivel de publicaciones referidas a la etapa protohistórica era abrumadoramente mayor que el de otros periodos históricos. Sólo en los últimos años se ha avanzado en el conocimiento de otras manifestaciones históricas, especialmente el mundo romano. En cualquier caso, el nivel global de interpretación elaborado no se corresponde con el volumen de datos disponibles, según hemos justificado en La Carta de Riesgo de Huelva (CAMPOS; GÓMEZ; LÓPEZ, 2000) y en la, hasta ahora, única síntesis histórico-arqueológica que realiza la puesta al día del conjunto de datos conocidos (GÓMEZ TOSCANO; CAMPOS CARRASCO, 2001).

Pero sin duda, el cambio más significativo se ha producido en la gestión de las intervenciones urbanas. A partir de 1999, como se ha señalado, cambia radicalmente el panorama anteriormente descrito. La redacción de la Carta de Riesgo de la Ciudad de Huelva permitió la elaboración del expediente de incoación de la zona arqueológica de Huelva con una nueva delimitación que perfila una zona arqueológica mucho más amplia y compleja que la contemplada en el PGOU de 1980, estableciendo ámbitos precisos de protección teniendo en cuenta el diagnóstico previo establecido en la Carta de Riesgo del Casco Antiguo de la Ciudad de Huelva y las nuevas experiencias adquiridas en los últimos años. Esto conlleva un nuevo procedimiento que consiste en que a la financiación pública, tanto municipal como autonómica, de las diferentes actuaciones arqueológicas, se incorporan los promotores privados que han de sufragar los costes de las intervenciones arqueológicas en las obras que promueven.

Siguiendo este procedimiento, desde noviembre de 1999, como ya se ha indicado, se han realizado unas 220 excavaciones y seguimientos arqueológicos de diverso alcance que han permitido establecer diferentes acciones encaminadas a la protección, conservación, revalorización y difusión del patrimonio histórico-arqueológico de la ciudad de Huelva.

Finalmente, y relacionado con lo anterior, en lo que a la conservación de restos se refiere, la referida Declaración también establece un punto de inflexión 

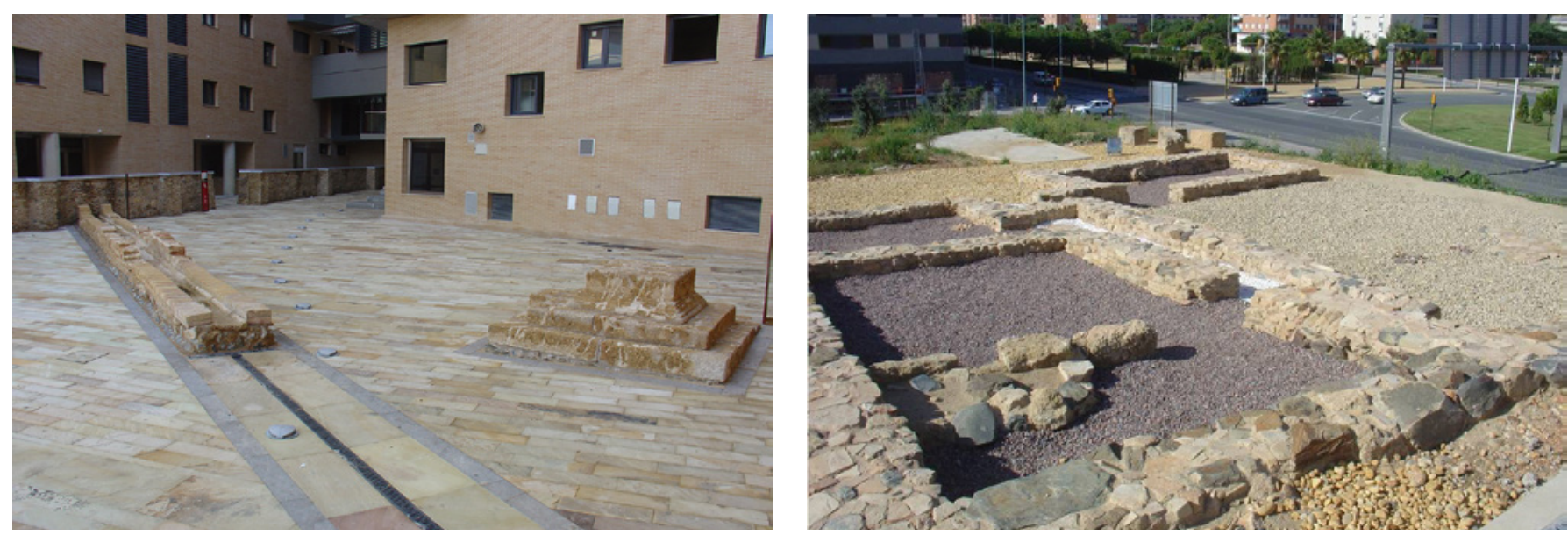

A la izquierda, puesta en valor de la necrópolis del Colegio Francés

A la derecha, puesta en valor de la villa romana de La Almagra | fotos Grupo de Investigación Vrbanitas Arqueología y Patrimonio en este aspecto, pues salvo los restos del conocido Muro de San Pedro, conservado por iniciativa privada, nada se había conservado en la ciudad hasta ese momento, lo que ha supuesto la destrucción de una muestra significativa de restos para comprender la evolución histórica de la ciudad. En los últimos años han sido varias las iniciativas orientadas hacia la conservación y difusión de restos, como son los casos de la calle Arquitecto Pérez Carasa, plaza de San Pedro, antiguo Colegio Francés, villa de La Almagra y Parque Moret. A pesar de ello, creemos que es todavía una asignatura pendiente que la ciudad en su conjunto debe superar con una apuesta más decidida a la hora de tomar decisiones sobre la integración de restos.

\section{LAS PERSPECTIVAS DE FUTURO}

Sin duda, el futuro de la investigación en la ciudad de Huelva pasa por, superando el actual Plan General de Investigación, el diseño de un proyecto de ciudad, donde la arqueología urbana se posicione como una actividad fundamental. El hecho de tratarse de un enclave que se extiende desde los albores del I milenio a. de C. hasta nuestros días sin solución de continuidad y de presentar un alto grado de conservación, no sólo del registro arqueológico sino también de los restos inmuebles, otorga al proyecto un alto valor en lo que al desarrollo cultural y turístico de la ciudad se refiere.

Por otro lado, los beneficios de una investigación de estas características podrían ser aprovechados por la propia dinámica de planeamiento y administración urbanística del ente local mediante la actualización continua de la carta de riesgo.

Con todas las premisas anteriores, la existencia de un proyecto general de arqueología urbana en la zona arqueológica de Huelva, de acuerdo con las 
evidencias mostradas en apartados anteriores, encuentra su más lógica justificación, tanto desde la perspectiva de la gestión del patrimonio histórico de la ciudad por las instituciones responsables de su protección y difusión, como desde las que asuman su investigación y divulgación científica.

Con este proyecto se puede aglutinar la información que se genere en las diversas actuaciones arqueológicas que se realicen en un futuro, cuyo fin, al estar fundamentalmente encaminado al diagnóstico patrimonial de zonas o parcelas urbanas, podría perder el necesario componente histórico-científico que debe presidir la investigación que se lleve a cabo en el ámbito de una ciudad superpuesta como Huelva.

Por otra parte, dado que las intervenciones en la ciudad están garantizadas con las figuras de protección necesarias, un proyecto de arqueología urbana representaría poner en práctica una tendencia que, de acuerdo con la experiencia adquirida en la Comunidad Autónoma de Andalucía en los últimos años, parece la culminación de un modelo de gestión del patrimonio histórico-arqueológico imprescindible en este milenio.

Desde esta perspectiva, serán pues los dos mecanismos citados, la Declaración de Huelva como zona arqueológica, y la redacción de la carta de riesgo, incluidas en el Plan General de Ordenación Urbana, los que faculten un nuevo marco de diálogo entre los ciudadanos, ávidos de conocer su pasado, los agentes de desarrollo inmobiliario, generadores de riqueza y progreso, la Universidad, garante de la investigación, y los poderes públicos, responsables de garantizar el futuro del pasado. Confluyen, de este modo, toda la diversa gama de esfuerzos en planificación e intervención de facto sobre la ciudad, y es en este plano de confluencia donde se pone de manifiesto el carácter sintético y dinámico del problema urbano: la ciudad histórica como proyecto en continuo desarrollo.

Las relaciones actuales entre planeamiento urbanístico, intervención arquitectónica en el patrimonio inmobiliario y arqueología preventiva y sistemática, nos llevan a la consideración de la ciudad histórica como objeto proyectual, donde desde el concepto de arqueología urbana se integraría de forma plena en lo que hemos llamado el proyecto ciudad. Pero esta integración, sin dudas, pasa necesariamente, como se ha defendido, por la articulación de un proyecto general de investigación de futuro donde, respetando la libertad científica de los diferentes investigadores o profesionales de la arqueología que lleven a cabo las intervenciones de urgencia, se pueda generar y procesar el volumen de información obtenida mediante registros homologados, que permita el rescate y la reconstrucción de la memoria histórica de la ciudad de Huelva (CAMPOS; VIDAL, 2013). 


\section{BIBLIOGRAFÍA}

- AlBELDA, J.; OBERMAIER, H. (1931) El casco griego de Huelva. Boletín de la Real Academia de la Historia, tomo 98, cuaderno II (abril-junio, 1931), pp. 642-648

- ALMAGRO BASCH, M. (1940) El hallazgo de la ría de Huelva y el final de la Edad del Bronce en el Occidente de Europa. Ampvrias. Revista de Arqueología, Prehistoria y Etnografía, II, 1940, pp. 85-143

- ALMAGRO BASCH, M. (1957) Las fíbulas de codo de la ría de Huelva. Su origen y cronología. Cuadernos de trabajo de la Escuela Española de Historia y Arqueología en Roma, n. ${ }^{\circ}$ 9, 1957, pp. 7-46

- ALMAGRO-GORBEA, M.; CASADO, D.; FONTES, F.; MEDEROS, A.; TORRES, M. (2004) Casco corintio de la Ría de Huelva. En ALMAGRO-GORBEA, M.; CASADO, D.; FONTES, F.; MEDEROS, A.; TORRES, M. Catálogo del Gabinete de Antigüedades de la Real Academia de la Historia. Prehistoria. Antigüedades Españolas I. Madrid: Real Academia de Historia, 2004, pp. 174-176

- AMO Y DE LA HERA, M. DEL; BELÉN DEAMOS, M. (1981) Estudio de un corte estratigráfico en el Cabezo de San Pedro. Huelva Arqueológica, n. ${ }^{\circ}$ 5, 1981, pp. 57-148

- AMO Y DE LA HERA, M. DEL (1976) Restos materiales de la población romana de Onuba. Huelva Arqueológica, n. ${ }^{\circ} 2,1976$, pp. 11-196

- BELÉN DEAMOS, M.; FERNÁNDEZ-MIRANDA, M.; GARRIDO ROIZ, J. P. (1977) Los orígenes de Huelva: excavaciones en los Cabezos de San Pedro y La Esperanza. Huelva Arqueológica, n. ${ }^{0} 3,1977$, pp. 13-171

- BERMEJO MELÉNDEZ, J.; CAMPOS CARRASCO, J. M.; RODRÍGUEZ-VIDAL, J. (2017) Las estructuras portuarias de Onoba Aestuaria: Un puerto pesquero y de control imperial. En CAMPOS CARRASCO, J. M.; BERMEJO MELÉNDEZ, J. (ed.) Los Puertos Atlánticos Béticos y Lusitanos y su relación comercial con el Mediterráneo. Roma: “L’Erma" di Bretschneide, 2017, pp. 207-243 (Hispania Antigua-Serie Arqueologica)

- BLÁZQUEZ MARTÍNEZ, J. M.; LUZÓN NOGUÉ, J. M.; GÓMEZ, F.; CLAUSS, K. (1970) Huelva Arqueológica. Las cerámicas del Cabezo de San Pedro. Huelva: Diputación Provincial de Huelva, 1970

- BLÁZQUEZ MARTÍNEZ, J. M.; RUIZ MATA, D.; REMESAL RODRÍGUEZ, J.; RAMÍREZ SÁDABA, J. L.; CLAUSS, K. (1979) Excavaciones en el Cabezo de San Pedro (Huelva). Campaña de 1977. Madrid: Ministerio de cultura. Dirección General del Patrimonio Artístico, Archivos y Museos. Subdirección General de Arqueología, 1979 (Excavaciones Arqueológicas en España, 102)

- CABRERA BONET, P. (1986) La presencia griega en Huelva: los materiales griegos. Homenaje a Luis Siret (1934-1984). Sevilla: Consejería de Cultura, pp. 575-583
- CAMPOS CARRASCO, J. M. (2001-2002) La ciudad romana de Onuba (Huelva). Una revisión arqueológica. Anales de Prehistoria y Arqueología, n. ${ }^{\circ}$ 17-18, 2001-2002, pp. 329-340

- CAMPOS CARRASCO, J. M. (2006) Huelva, desde los inicios hasta la Edad Media. En LARA RÓDENAS, M. J. DE; ECHENAGUSIA BELDA, J.; ORTEGA, C.; CAMPOS CARRASCO, J. M. Huelva. Barcelona: Editorial Lunwerg, 2006, pp. 13-25

- CAMPOS CARRASCO, J. M. (2011) Onoba Aestuaria. Una ciudad portuaria en los confines de la Baetica. Huelva: Ayuntamiento, Concejalía de Cultura, 2009

- CAmpos CARRAsco, J. M. (2016) Plan General de investigación arqueológica: Zona Arqueológica de Huelva. Consejería de Cultura. Junta de Andalucía. Inédito

- CAMPOS CARRASCO, J. M.; BERMEJO MELÉNDEZ, J. (2017) Los suburbios de Onoba Aestuaria, el área portuaria. En PANZRAM, S. OPPIDIUM-CIVITAS-URBS. Stadteforschung auf der Iberischen Halbinsel Zwischen Rom und al-Andalus. Berlín: LIT Verlag, 2017, pp. 739-766

- CAMPOS, J. M.; GÓMEZ, F.; LÓPEZ, M. A. (2000) Carta de Riesgo de la Ciudad de Huelva. Excmo. Ayuntamiento de Huelva. Inédita

- CAMPOS, J. M.; VIDAL, N. O. (2013) Arqueología urbana en Huelva: balance y perspectivas de futuro. En GÓMEZ TOSCANO, F. Arqueología en la Provincia de Huelva: homenaje a Javier Rastrojo Lunar. Huelva: Servicio de Publicaciones Universidad de Huelva, Asociación Profesional de Arqueólogos de la Provincia de Huelva, 2013, pp. 27-36

- DElgado Aguilar, S. (2016) Onoba Aestuaria [en línea]. Tesis doctoral inédita. Universidad de Huelva, 2016 <http://rabida.uhu.es/dspace/handle/10272/12086> [Consulta: 08/11/2018]

- FERNÁNDEZ JURADO, J. (1988-1989) Tartessos y Huelva. Huelva Arqueológica, n. ${ }^{\circ}$ 10-11 (1), 1988-1989

- FERNÁNDEZ JURADO, J.; RUFETE TOMICO, P.; GARCÍA SANZ, C. (1992) Análisis y definición de la cultura tartésica según Tejada la Vieja (Escacena) y Huelva. Síntesis de resultados. En CAMPOS CARRASCO, J. M.; NOCETE CALVO, F. (coord.) Investigaciones Arqueológicas en Andalucía (1985-1992). Proyectos. Huelva, pp. 79-85 y 497-499

- FERNÁNDEZ JURADO, J.; CABRERA BONET, P. (1987) "Comercio griego en Huelva a fines del siglo $V$ a.C." Simposio Internacional Grecs et Ibères au IVè siècle $a$. J. C. Revue d'Etudes Anciens, tomo 89, n. ${ }^{\circ} 3-4,1987$, pp. 149-159

- FERNÁNDEZ JURADO, J.; GARCÍA SANZ, C.; RUFETE TOMICO, P. (1997) De Tartessos a Onuba. 15 años de 
arqueología en Huelva. Huelva: Diputación Provincial de Huelva, 1997

- gARCíA ALFONSO, E. (2010) Elementos de carro. En LÓPEZ, M. D.; GARCÍA, E. (ed.) Cádiz y Huelva. Puertos Fenicios del Atlántico. Sevilla: Fundación Cajasol, Junta de Andalucía, 2010, pp. 302-303

- GARRIDO ROIZ, J. P.; ORTA GARCíA, M. E. (1969) Cerámicas prerromanas de Huelva. Trabajos de Prehistoria, 26, 1969, pp. 327-335

- GARRIDO ROIZ, J. P. (1970) Excavaciones en la necrópolis de la Joya (1. a y 2. ${ }^{a}$ campañas). Madrid: Ministerio de Educación y Ciencia. Dirección General de Bellas Artes, Comisaría General de Excavaciones Arqueológicas, 1970 (Excavaciones Arqueológicas en España, 71)

- GARRIDO ROIZ, J. P.; ORTA GARCíA, E. M. (1978) Excavaciones en la necrópolis de La Joya, Huelva II. $\left(3^{a}, 4^{a}\right.$ y $5^{a}$ Campañas). Madrid: Ministerio de Educación y Ciencia. Dirección General de Bellas Artes, Comisaría General de Excavaciones Arqueológicas, 1970-1978 (Excavaciones Arqueológicas en España, 96)

- GARRIDO ROIZ, J. P.; ORTA GARCíA, M. E. (1989) La necrópolis y el hábitat orientalizante de Huelva. Itinerarios de Monumentos. Huelva: Consejería de Cultura, Delegación Provicial de Huelva, 1989, pp. 5-93

- gÓMEz toscano, F.; CAMPos CARRASCO, J. M. (2001) Arqueología en la Ciudad de Huelva (1966-2000). Huelva: Universidad, 2001

- LÓPEZ, M. D.; GARCíA, E. (eds.) (2010) Cádiz y Huelva. Puertos Fenicios del Atlántico. Sevilla: Fundación Cajasol, Junta de Andalucía, 2010

- MALUQUeR DE MOTES, J. (1969) Tartessos y sus problemas: Actas del V Symposium Internacional de Prehistoria Peninsular (Jerez de la Frontera. 1968). Barcelona: Universidad de Barcelona, 1969

- OlMOS ROMERA, R. (1982) La cerámica griega en el Sur de la Península Ibérica. La aportación de Huelva. La Parola del Passato, n. ${ }^{\circ}$ 37, 1982, pp. 393-406

- OlMOS ROMERA, R. (1988) El casco griego de Huelva. Clásicos de la arqueología de Huelva, n. ${ }^{\circ} 1,1988$, pp. 3778

- OlMOS ROMERA, R.; CABRERA BONET, P. (1980) Nuevo fragmento de Clitias en Huelva. Archivo Español de Arqueología, vol. 53, n. ${ }^{\circ}$ 141-142, 1980, pp. 5-14

- ORTA gARCÍA, E. M.; GARRIDO ROIZ, J. P. (1963) La tumba orientalizante de la Joya, Huelva. Madrid: Consejo Superior de Investigaciones Científicas, Instituto Español de Prehistoria (Trabajos de Prehistoria, XI)

- ROUILLARD, P. (1978) Fragmentos griegos de estilo geométrico y corintio medio en Huelva. Huelva Arqueológica, III, 1978, pp. 397-401

- RUFETE TOMICO, P.; GARCíA SANZ, C. (1995) Huelva en época tartésica. Huelva: Diputación de Huelva, 1995

- RUIZ MATA, D. (1986) Aportación al análisis de los inicios de la presencia fenicia en Andalucía Sudoccidental según las excavaciones del Cabezo de San Pedro (Huelva), S. Bartolomé (Almonte, Huelva), Castillo de Doña Blanca (Puerto de Santa María, Cádiz) y El Carambolo (Camas, Sevilla). En Homenaje a Luis Siret (1934-1984). Sevilla: Consejería de Cultura, 1986, pp. 537-556

- RUIZ MATA, D. (1995) Las cerámicas del Bronce Final. Un soporte tipológico para delimitar el tiempo y el espacio tartésico. Tartessos 25 años después (1968-1993). Jerez de la Frontera: Ayuntamiento, 1995, pp. 265-313

- RUIZ MATA, D.; BLÁZQUEZ MARTÍNEZ, J. M.; MARTÍN DE LA CRUZ, J. C. (1981) Excavaciones en el Cabezo de San Pedro (Huelva). Campaña de 1978. Huelva Arqueológica, n. ${ }^{\circ}$ 5, 1981, pp. 149-316

- SCHUBART, H.; GARRIDO ROIZ, J. P. (1967) Probegrabung auf dem Cabezo de la Esperanza un Huelva. Madrider Mitteilungen, n. ${ }^{\circ} 8,1967$, pp. 123-158

- toscano, C.; CAMPOS, J. M. (2018) Elementos religiosos orientales en la Turdetania atlántica: ¿novedad o perduración del período orientalizante? Folia Phoenicia, n. ${ }^{\circ}$ 2, 2018, pp. 341-348

- VIDAL, N. O.; CAMPOS, J. M. (2006) Las necrópolis de Onuba. Anales de Arqueología Cordobesa, 17, vol. II, 2006, pp. 13-34

- VALLEJO SÁNCHEZ, J. I. (2010) Recipientes de bronce. En LÓPEZ, M. D.; GARCíA, E. (ed.) Cádiz y Huelva. Puertos Fenicios del Atlántico. Sevilla: Fundación Cajasol, Junta de Andalucía, 2010, pp. 310-311 


\section{Los lugares colombinos de Huelva: historia, cultura y naturaleza}

Diego Ropero-Regidor | Archivo Histórico Municipal, Biblioteca Iberoamericana de Moguer

URL de la contribución <www.iaph.es/revistaph/index.php/revistaph/issue/view/4292>

\section{RESUMEN}

La historiografía americanista dedicó en el pasado siglo una atención especial a los lugares colombinos de la provincia de Huelva. Los preparativos y la realización del viaje de Colón forman parte del relato histórico de La Rábida, Palos de la Frontera y Moguer, tríada espacial con el tiempo dentro que ha sabido recuperar y potenciar un legado que comparten como una de las señas de identidad que más han marcado su devenir. En el siglo XIX se dieron las condiciones para que el monasterio de La Rábida no fuera destruido, sumándose a los planes de su rehabilitación el gobierno y muchas personalidades de la política y la cultura de España y América. EI IV Centenario del Descubrimiento supuso el punto de inflexión hacia la modernidad; desde entonces este rincón onubense, su historia, los edificios vinculados a la gesta colombina, como el modesto cenobio franciscano, la iglesia de San Jorge, de Palos, y el monasterio de Santa Clara, de Moguer, y su entorno urbano y paisajístico proyectan unos valores que son reconocidos por la sociedad en general. Las últimas y recientes inversiones públicas en estos lugares colombinos, especialmente las realizadas en torno a 1992, fueron destinadas a restaurar y revitalizar sus monumentos históricoartísticos, y, además, a dotar dicho espacio con nuevas instalaciones culturales. Las huellas de Colón, los Pinzón y los hermanos Niño, y las tres naves descubridoras -cuyas réplicas se encuentran en el recinto museístico del Muelle de las Carabelas-, igual que entonces, siguen rememorando en el estuario del río Tinto una de las epopeyas más universales.

\section{Palabras clave}

América | Colón | Descubrimiento | España | Gestión | La Rábida (Huelva) | Lugares colombinos | Moguer (Huelva) | Palos de la Frontera (Huelva) | Patrimonio | 1492 | 


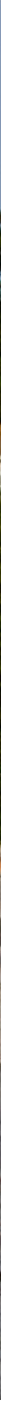

Santuario de Nuestra Señora de la Cinta. Huelva | foto J. Miguel Marchena 
El espacio que alberga los lugares colombinos en la provincia de Huelva proyecta la memoria de la aventura americana, episodio que ha tenido momentos de olvido y reivindicaciones. En 1828, el escritor Washington Irving visitó dichos lugares y alertó al mundo del abandono del monasterio de La Rábida, epicentro donde Colón fue arropado por los frailes franciscanos que le pusieron en contacto con armadores y navegantes notables de Palos y Moguer. Tras siete años deambulando por la corte en busca de apoyos para su viaje, los Reyes Católicos finalmente dispusieron que fueran atendidas sus demandas. El 17 de abril de 1492 se firmaron las Capitulaciones en Santa $\mathrm{Fe}$, en las inmediaciones de Granada, capital del reino nazarí que había sido tomada a principios de ese año. El apoyo de los frailes Antonio de Marchena y Juan Pérez, y de Martín Alonso Pinzón, de Palos, y los hermanos Niño, de Moguer, fue decisivo para conseguir las naves y atraer a la tripulación que protagonizaron una de las epopeyas más importantes de la historia de la humanidad. El viaje de descubrimiento de la nao Santa María y las carabelas Pinta y Niña, revolucionó -en opinión de Johannes Stradanus (1580)- la forma de pensar del Renacimiento.

La recuperación para el acervo cultural de tan singular espacio han llevado a los responsables de su gestión a optimizar los recursos de los elementos que componen dicho ámbito, con el objetivo de destacar su valor excepcional universal para que La Rábida y los lugares colombinos sean incluidos en la lista de Patrimonio de la Humanidad. Las reivindicaciones del protagonismo onubense en el Descubrimiento se inician en el siglo XIX, a partir de las reacciones que provocó la desaparición del modesto cenobio rabideño tras la desamortización. El gobernador Mariano Alonso del Castillo influyó para impedir su derribo. Tras la oportuna visita de los duques de Montpensier, el monasterio fue declarado monumento nacional en 1856. Con posterioridad se sucedieron intervenciones de calado en el edificio y su entorno a cargo del arquitecto Ricardo Velázquez Bosco para que pudieran acoger los fastos del IV Centenario del Descubrimiento.

Tras varias décadas sin avances significativos, salvo algunos eventos y actuaciones puntuales como el vuelo transatlántico del hidroavión Plus Ultra (1926) y la erección del monumento a Colón en la Punta del Sebo (1929), obra de la artista norteamericana Gertrudis Whitney, fue creada la Universidad Hispanoamericana (1943), institución que ha pasado por distintas etapas, aunque sigue profundizando en las estrechas relaciones que Huelva mantiene con Iberoamérica (en la actualidad es una de las sedes de la UNIA). Coincidiendo con los planes de desarrollo industrial en la década de los sesenta de siglo pasado, los lugares colombinos fueron declarados conjunto histórico-artístico, protección que ha sido reforzada y ampliada recientemente como sitio histórico en el Catálogo General del Patrimonio Histórico Andaluz. En 1992, fecha emblemática para la comunidad iberoamericana, La Rábida, Palos de la Frontera y Moguer cogieron de nuevo el testigo con 


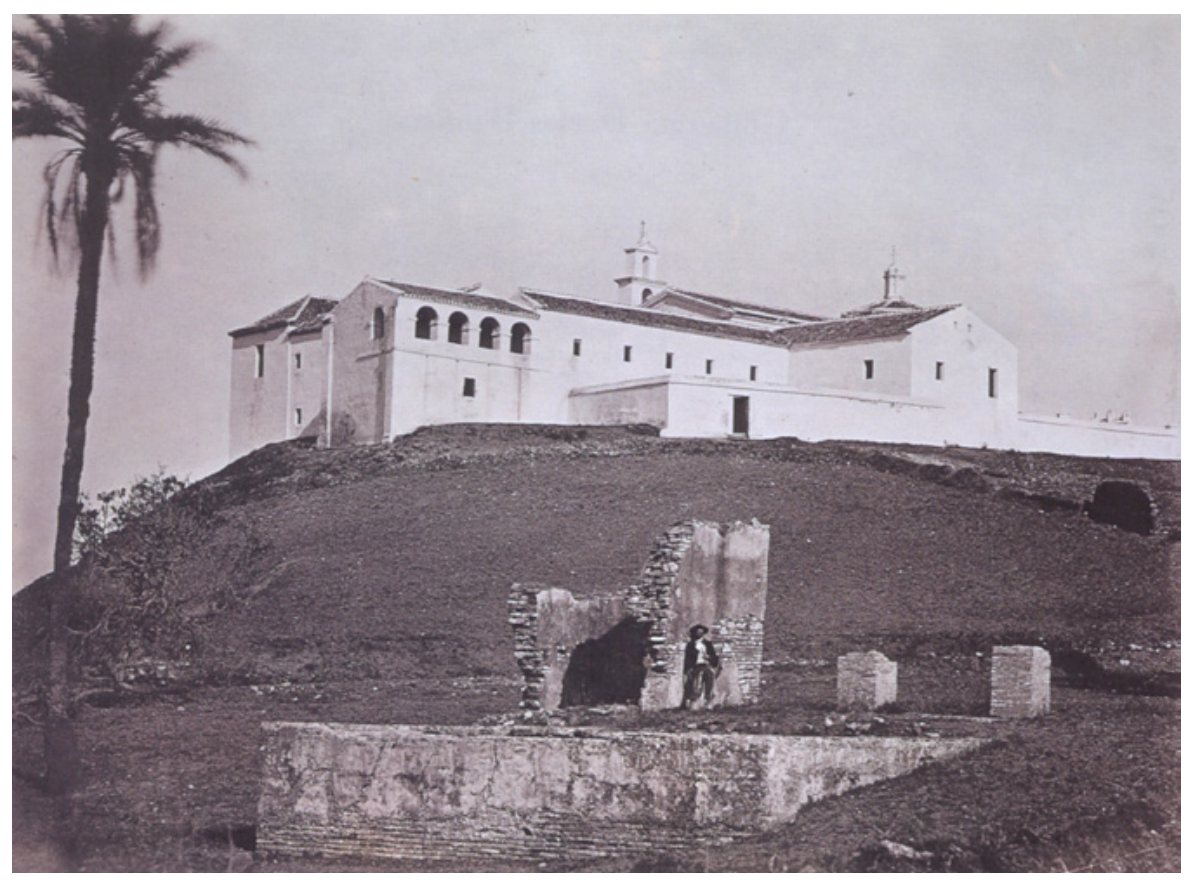

motivo del $\vee$ Centenario. En esta ocasión se produjo un avance extraordinario en cuanto a la modernización de programas, infraestructuras y nuevas dotaciones para los espacios colombinos: reformas y ampliación del monasterio, construcción del auditorio y edificio administrativo del parque botánico "Celestino Mutis", en La Rábida; rehabilitaciones de los conventos de Santa Clara y San Francisco, y construcción del teatro Felipe Godínez, en Moguer; iglesia de San Jorge, de Palos; y el Gran Teatro y la Casa Colón, en Huelva. También se realizaron mejoras en la red viaria con la puesta en servicio de la autopista del $\vee$ Centenario, los puentes del Odiel y el internacional del Guadiana. Los reyes visitaron los lugares colombinos y en el monasterio de La Rábida hubo un consejo de ministros presidido por el monarca. Al año siguiente, el papa Juan Pablo II visitó las poblaciones colombinas, culminando en La Rábida su periplo con la coronación de la imagen de la patrona de Palos de la Frontera.

La Rábida y los lugares colombinos gravitan sobre una zona de escarpes y marismas con el río Tinto que desemboca en un amplio estuario hacia donde viene a morir también su hermano el Odiel. Este entorno, formado de gravas y arenas del Pleistoceno inferior, fue en la antigüedad asentamiento de tartesios, romanos y árabes, y en la época del Descubrimiento refugio estratégico de embarcaciones autóctonas y extranjeras. La ciencia náutica y la pericia de sus marineros atrajeron la atención de Cristóbal Colón, quien debía tener información precisa de ellos por los viajes comerciales que realizaban a Canarias y la costa africana (Guinea y Mina del Oro) donde se con-
El convento de La Rábida, 1875. José Spreafico | foto Biblioteca del Palacio Real, Madrid, reproducida en ROPERO-REGIDOR, D. (dir.) (1992) Los lugares colombinos y su entorno. Madrid: Fundación Ramón Areces, p. 96 

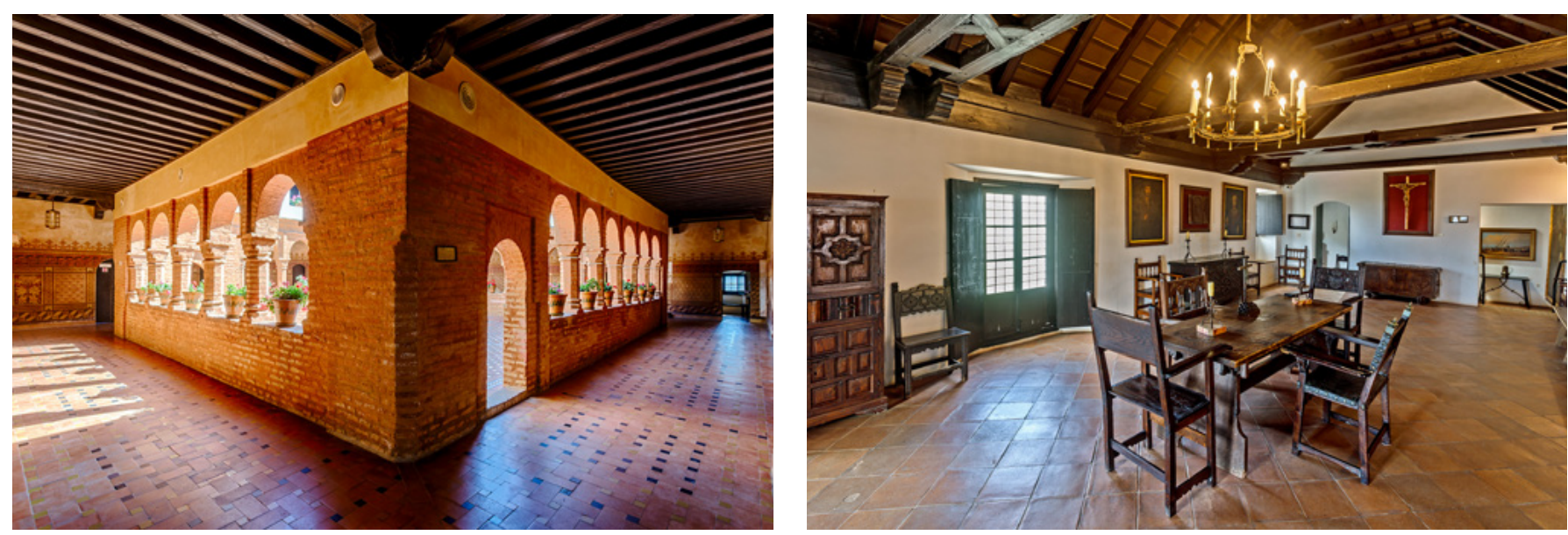

A la izquierda, claustro mudéjar del monasterio de La Rábida

A la derecha, sala del Padre Marchena en el convento de La Rábida | fotos Miguel Ángel Muñoz

centraban para las pesquerías y practicaban el corsarismo. En la Baja Edad Media, Palos, Moguer y Huelva eran poblaciones volcadas al mar, compartían negocios y embarcaciones y, aunque había rivalidad, nunca llegó la sangre al río, pues supieron aprovechar las oportunidades. Sus habitantes eran gente recia y competente, nada timorata, sabios por naturaleza, de lo contrario habría sido improbable que se sumaran los mejores marinos a la expedición colombina.

Desde el estratégico emplazamiento del monasterio de La Rábida, se contempla todo el estuario de los ríos Tinto y Odiel. Es, junto con la iglesia parroquial de San Jorge de Palos y el monasterio de Santa Clara de Moguer, uno de los monumentos colombinos. Sobre su origen existen opiniones encontradas; no obstante, los restos arqueológicos romanos e islámicos corroboran que esta zona ya estuvo habitada en la antigüedad. La fundación del convento parte del año 1412; ya entonces existía en dicho emplazamiento un marabito o ribat. Se trata de una construcción gótico-mudéjar, en la que destaca el uso del ladrillo, tapial y mampostería en muros, así como sillería de piedra en fachada principal, modelo repetido en las iglesias sevillanas de esta época. La fábrica fue completada a lo largo del siglo XV. En etapas posteriores, se llevaron a cabo distintas intervenciones, sobre todo las realizadas en el siglo XVII y en la segunda mitad del XVIII, como la cúpula de la iglesia, la espadaña o la galería alta del claustro mudéjar.

El convento, de factura modesta, nos retrotrae al tipo de cenobio o eremitorio franciscano alejado de los núcleos urbanos (entre 1623 y 1835, La Rábida fue centro de recolección de la Provincia Observante de Andalucía). El acceso al mismo se hace a través de una pequeña portería que conecta con la antigua sacristía donde podemos admirar los frescos de Vázquez Díaz el Poema del Descubrimiento (1929), que narran los momentos previos al viaje colombino, y el claustro de la Hospedería. La iglesia es de planta rectangu- 
lar con capillas laterales y presbiterio. El claustro mudéjar es de la primera mitad del XV; sus galerías son de ladrillo tallado, con arcos de medio punto peraltados, remarcados por alfices y apoyados en columnas octogonales. La planta alta fue construida coincidiendo con las reformas barrocas. En torno al mismo se encuentran las celdas primitivas, el refectorio, la sala capitular y otras dependencias anejas.

El histórico recinto franciscano acoge un museo colombino cuyo programa se complementa con el relato que ofrece el muelle de las Carabelas, donde se encuentran las réplicas de las tres naves que fueron construidas por la Sociedad Estatal con motivo del $\mathrm{V}$ Centenario del Descubrimiento. Otros edificios e instalaciones refuerzan el discurso y la identidad americanista de La Rábida: la Universidad Hispanoamericana (desde 1994 Internacional de Andalucía), el auditorio o foro Iberoamericano, el parque botánico "Celestino Mutis", donde podemos contemplar especies del continente americano, la Casita de Zenobia, la columna del IV Centenario, el monumento a Colón o el
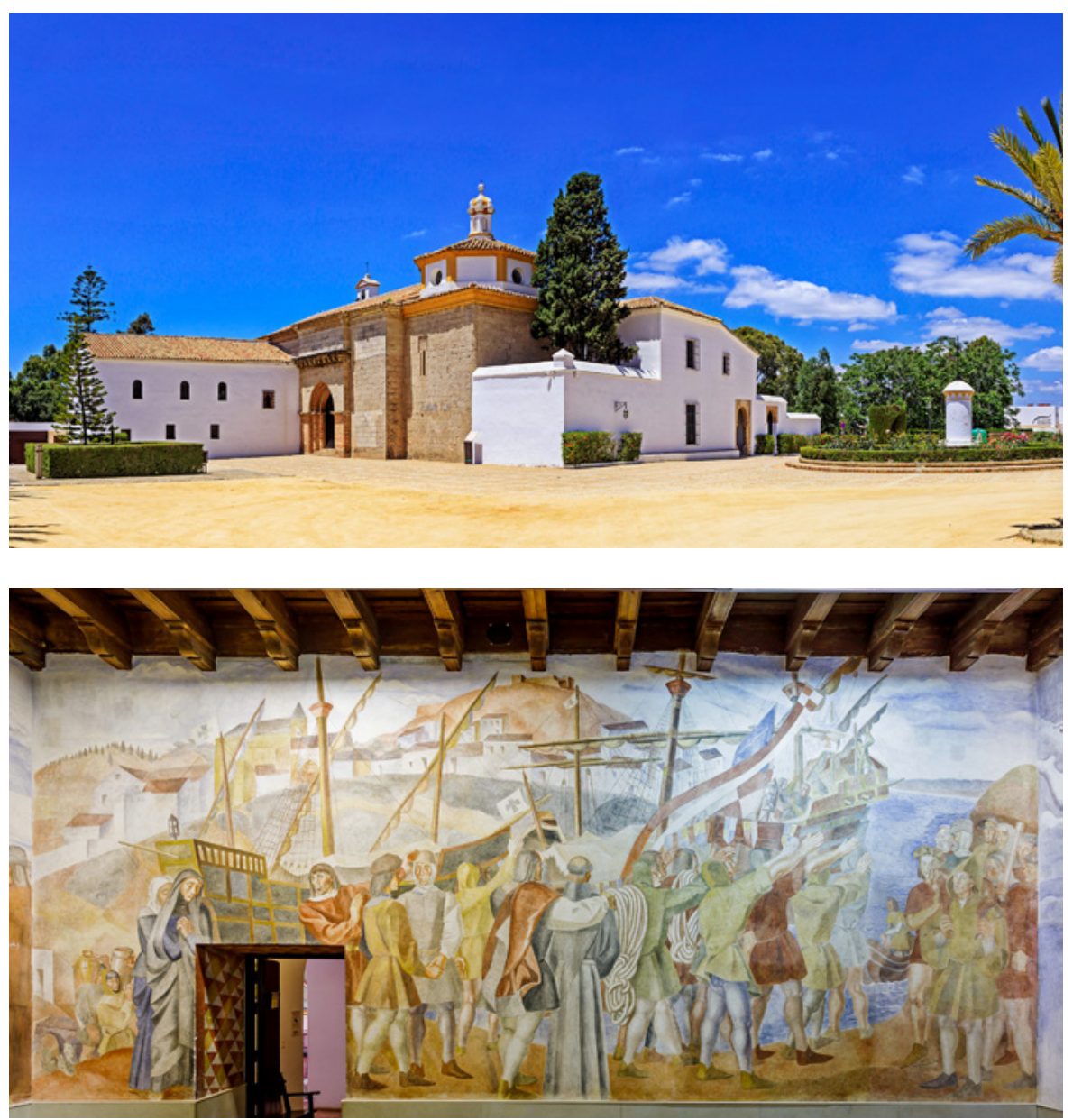

Panorámica del monasterio de La Rábida

Poema del Descubrimiento, "La partida", 1929. Daniel Vázquez Díaz. Monasterio de La Rábida | fotos Miguel Ángel Muñoz 


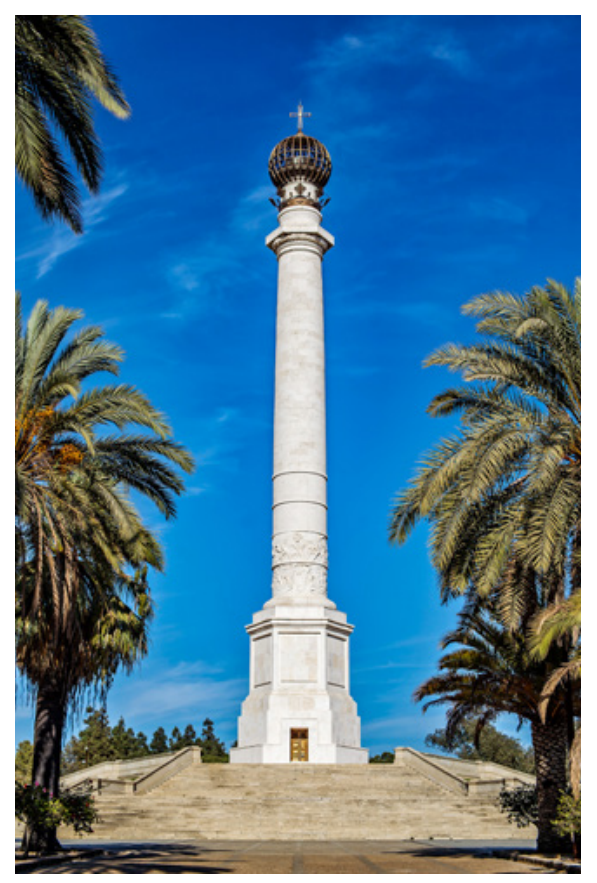

A la izquerda, columna conmemorativa del IV Centenario. La Rábida

Muelle de las Carabelas. La Rábida | fotos Miguel Ángel Muñoz

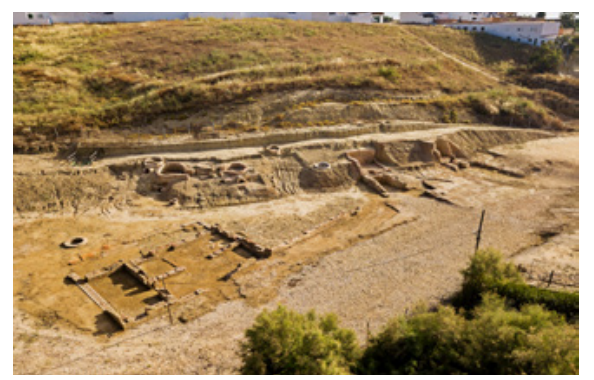

Restos del antiguo puerto de Palos de la Frontera | foto Miguel Ángel Muñoz

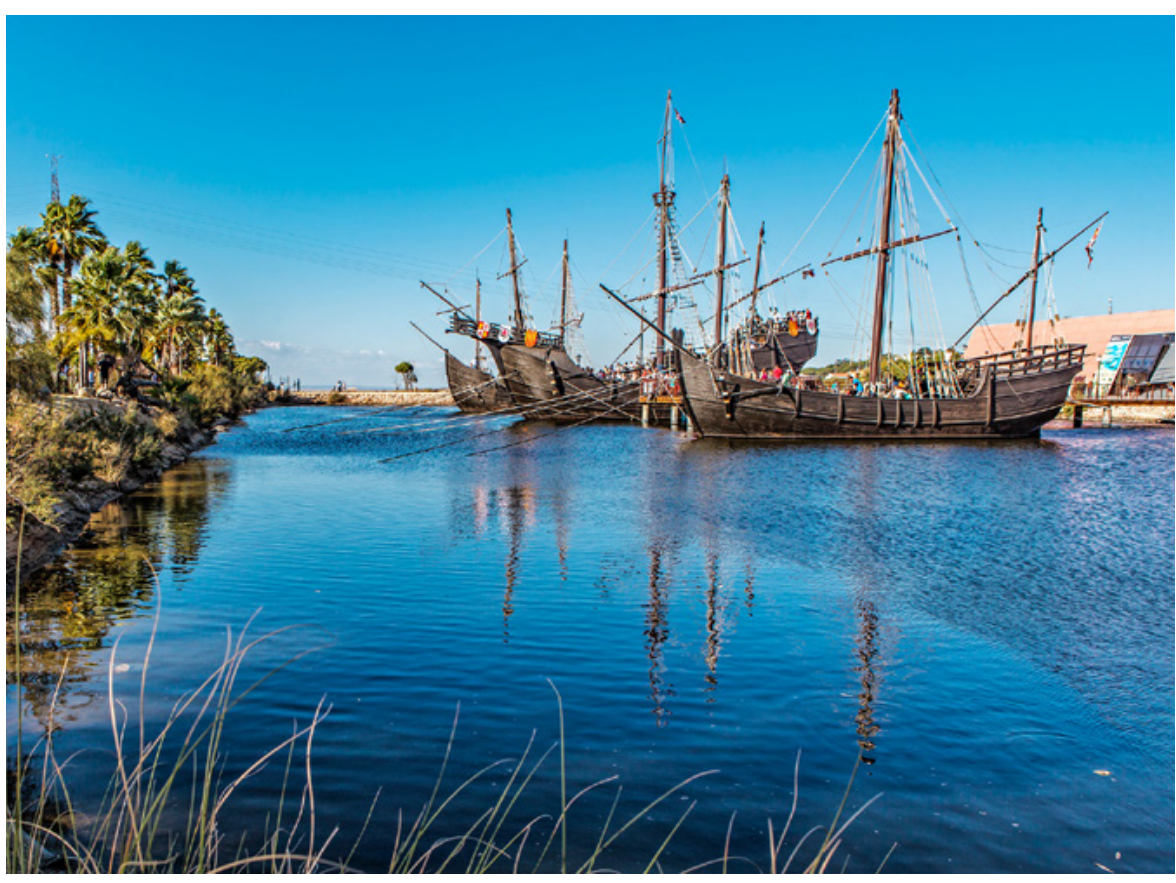

Ícaro, alegoría en homenaje al vuelo Plus Ultra, en el muelle de la Reina. El recinto rabideño cuenta con abundante arboleda, destacando el pino piñonero, y zonas ajardinadas.

Dejamos La Rábida y llegamos a Palos de la Frontera, una población muy pujante dedicada al cultivo del fresón, en cuyo término se localiza gran parte de la industria química, como la refinería y las instalaciones del puerto exterior de Huelva. En torno a la iglesia de San Jorge, edificio gótico-mudéjar construido en el siglo XIV, reformado o ampliado en los siglos XVI-XVIII, tuvo lugar la lectura de la pragmática real que ordenaba a los vecinos a entregar dos carabelas al futuro almirante de las Indias y el alistamiento de la tripulación. En sus inmediaciones se encuentran los restos del castillo, la casa museo de Martín Alonso Pinzón -solar que habitaron el ilustre marino y su familia-, la Fontanilla -un templete que abastecía de agua a la población y a las embarcaciones- y el antiguo puerto, cuyos cimientos han salido recientemente a la luz, tras varios años de campaña arqueológica, en lo que fue una ensenada del río Tinto, navegable en tiempos del Descubrimiento.

Moguer es, después de su vecina Palos de la Frontera, la segunda población colombina por su contribución al Descubrimiento. Si los Pinzón representan la élite entre los navegantes y armadores de la zona, los moguereños hermanos Niño estuvieron a la misma altura. La actividad pesquera, la construcción de barcos en el astillero de la Ribera y el intercambio entre los pueblos vecinos y otras plazas extranjeras, los estamentos sociales más favorecidos, 


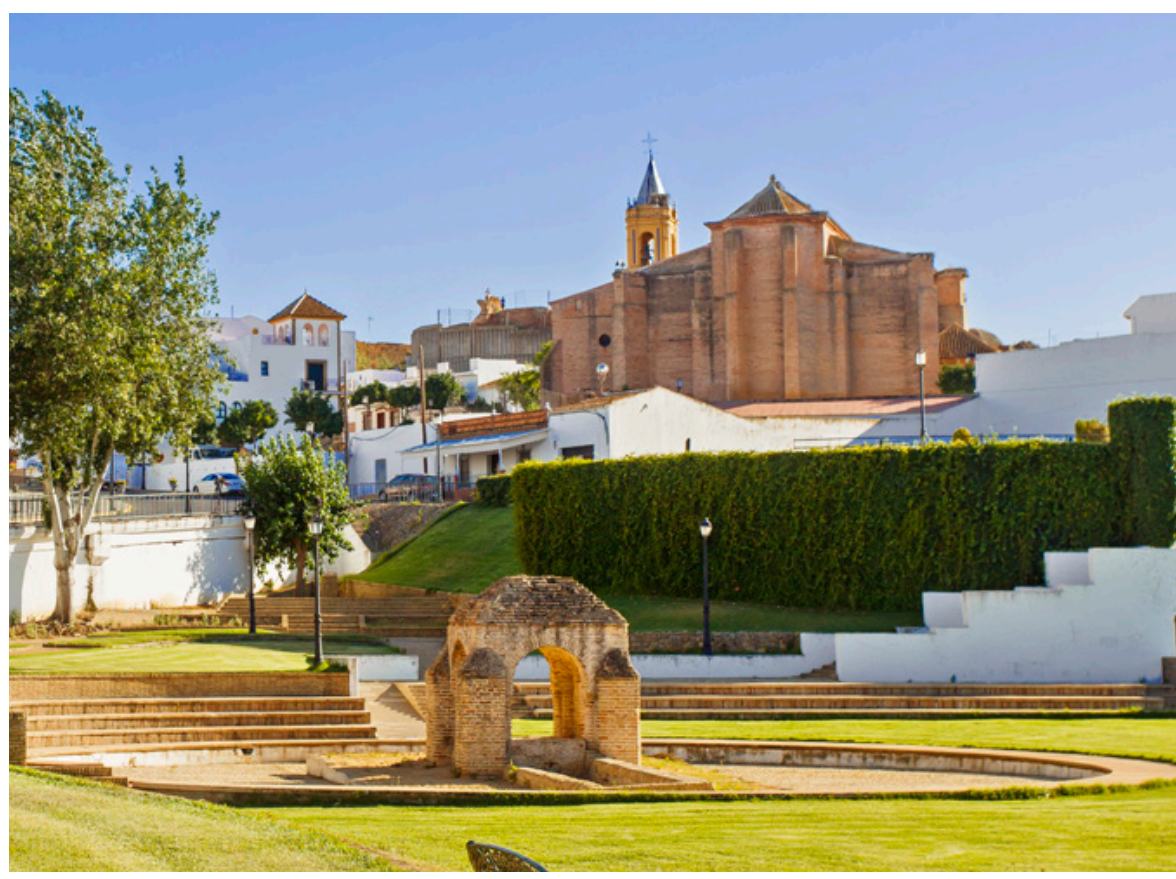

especialmente el religioso y aquellas personas que detentaron el poder local y controlaron la economía, contribuyeron a la prosperidad de la población, tradicionalmente agrícola y marinera, coincidiendo en el tiempo con las visitas que Cristóbal Colón realizó a Moguer, donde también negoció su viaje a las Indias con personas que tenían influencia dentro y fuera de la villa, destacando Inés Enríquez, abadesa del monasterio de Santa Clara, pariente del rey Fernando el Católico y, por supuesto, los hermanos Niño, dueños de la carabela Niña o Santa Clara, construida pocos años antes de la partida en la ribera de Moguer, y cuya participación en los viajes de descubrimiento dejaron huella en la historia de las navegaciones. Los preparativos del viaje se hicieron en Palos y en Moguer; por tanto, fue una empresa colectiva auspiciada por los reyes con el esfuerzo de Colón y la contribución de los Pinzón y los Niño y el resto de la marinería del estuario del Tinto.

El monasterio de Santa Clara es el edificio colombino de Moguer. Su fábrica gótico-mudéjar nos transporta a épocas de esplendor y poderío. Fue fundado en 1337 por Alonso Jofre Tenorio, almirante mayor de Castilla, para religiosas clarisas de la orden de San Francisco. De aspecto robusto, como si de una fortaleza se tratara, acoge en su planta irregular el templo de tres naves rematado con nervaduras góticas, en cuyo presbiterio se encuentra el cenotafio de los fundadores. El claustro principal o de las Madres es del siglo XIV; de estilo mudéjar, es el más antiguo de Andalucía; la doble galería sustentada por columnas de mármol toscanas es una ampliación de la segunda mitad del siglo XVI. De esta época son las construcciones y las reformas
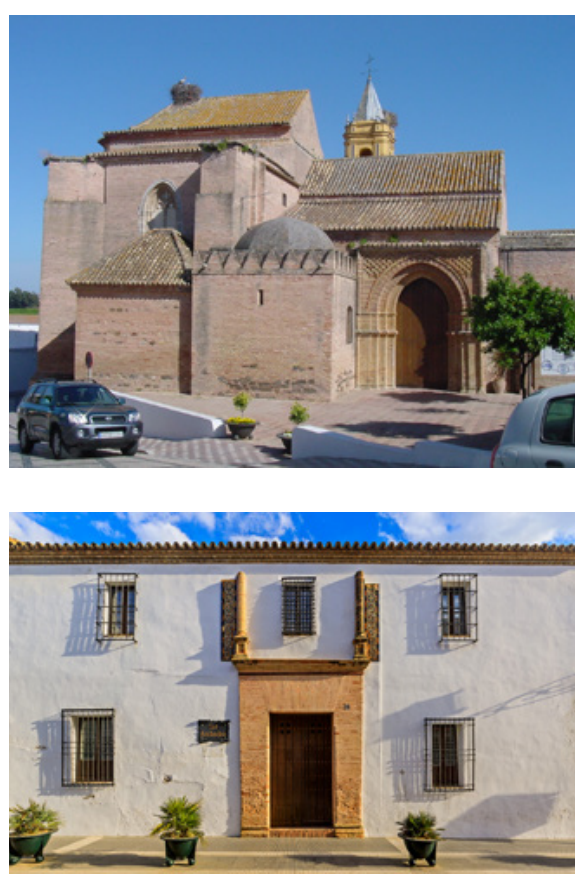

A la izquierda, iglesia de San Jorge Mártir. Palos de la Frontera | foto Miguel Ángel Muñoz

A la derecha arriba, iglesia de San Jorge Mártir. Puerta de los Novios. Palos de la Frontera | foto Diego Ropero

Casa Museo de Martín Alonso Pinzón. Palos de la Frontera | foto Miguel Ángel Muñoz

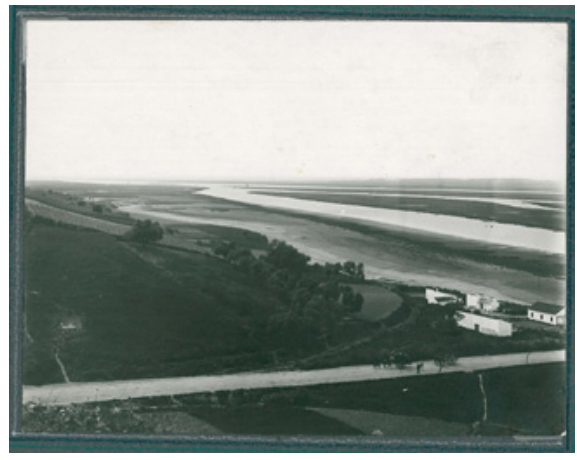

Arrecife y el río de Moguer. Principios del siglo XX | foto Archivo Histórico Municipal de Moguer 

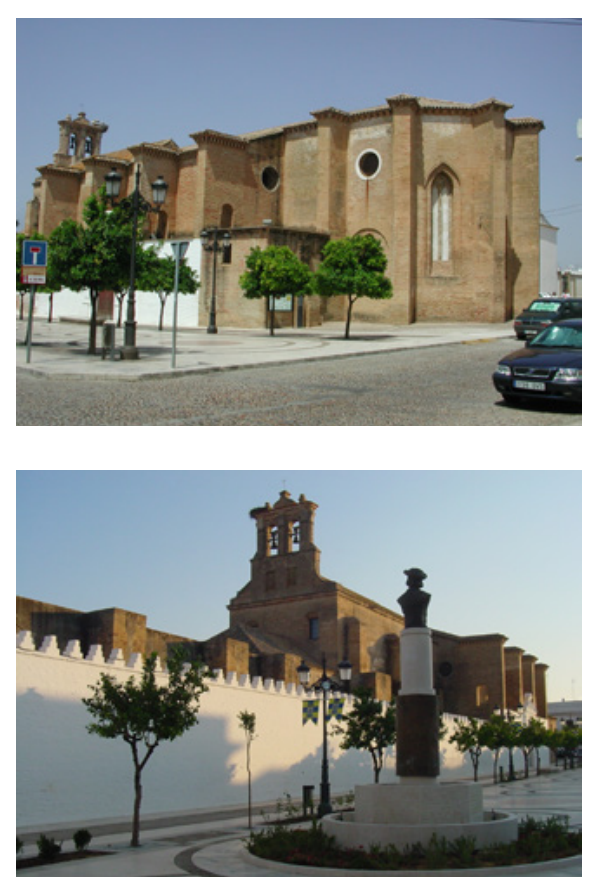

Arriba, ábside de la iglesia del monasterio de Santa Clara. Moguer

Abajo, monasterio de Santa Clara y el monumento a Colón. Moguer

A la derecha, castillo de Moguer | fotos Diego Ropero

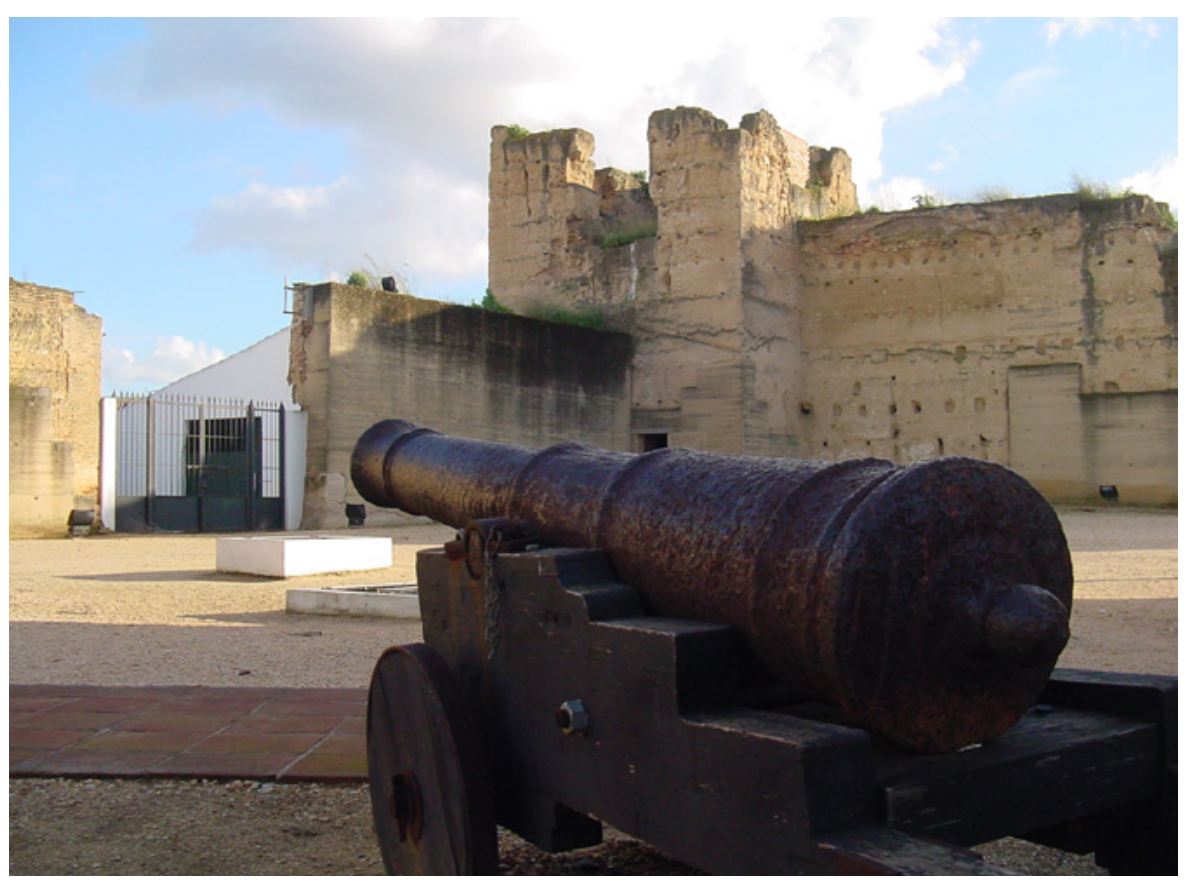

más importantes, como los dormitorios y la enfermería, a la que se llega a través del claustrillo mudéjar del siglo XV. Este modelo de construcción se reproduce en las iglesias fortificadas del valle de México y los claustros de la ciudad de Tunja (Colombia). En el interior del monasterio destacan, además del panteón de los fundadores, la sillería nazarí y las pinturas del coro bajo, y el retablo mayor, obra realizada por Jerónimo Velázquez en 1642. Cristóbal Colón oró e hizo decir una misa de acción de gracias en el interior del templo de las clarisas a su regreso del viaje de descubrimiento.

En sus inmediaciones, se encuentra el convento de San Francisco, edificio manierista sede del Archivo Histórico Municipal y la Biblioteca Iberoamericana, institución que contribuye a defender y proyectar la vocación americanista de Moguer. Merecen atención también el castillo medieval, la capilla del antiguo hospital del Corpus Christi, el ayuntamiento y la parroquia, estos dos últimos de la segunda mitad del siglo XVIII. Recorrer las calles de su casco histórico nos traslada a otras urbes hispanoamericanas, pues las relaciones con América fueron, durante siglos, una realidad ininterrumpida. La figura de Juan Ramón Jiménez, exiliado con su esposa Zenobia a América al inicio de la Guerra Civil, ha contribuido a conectar aún más ambas orillas. La casa museo del poeta reúne su biblioteca y muchos de los muebles y enseres que pertenecieron a la pareja.

Los lugares colombinos se localizan en la zona agroindustrial de Huelva, en cuya capital se encuentra el santuario de la Cinta, otro hito colombino que 


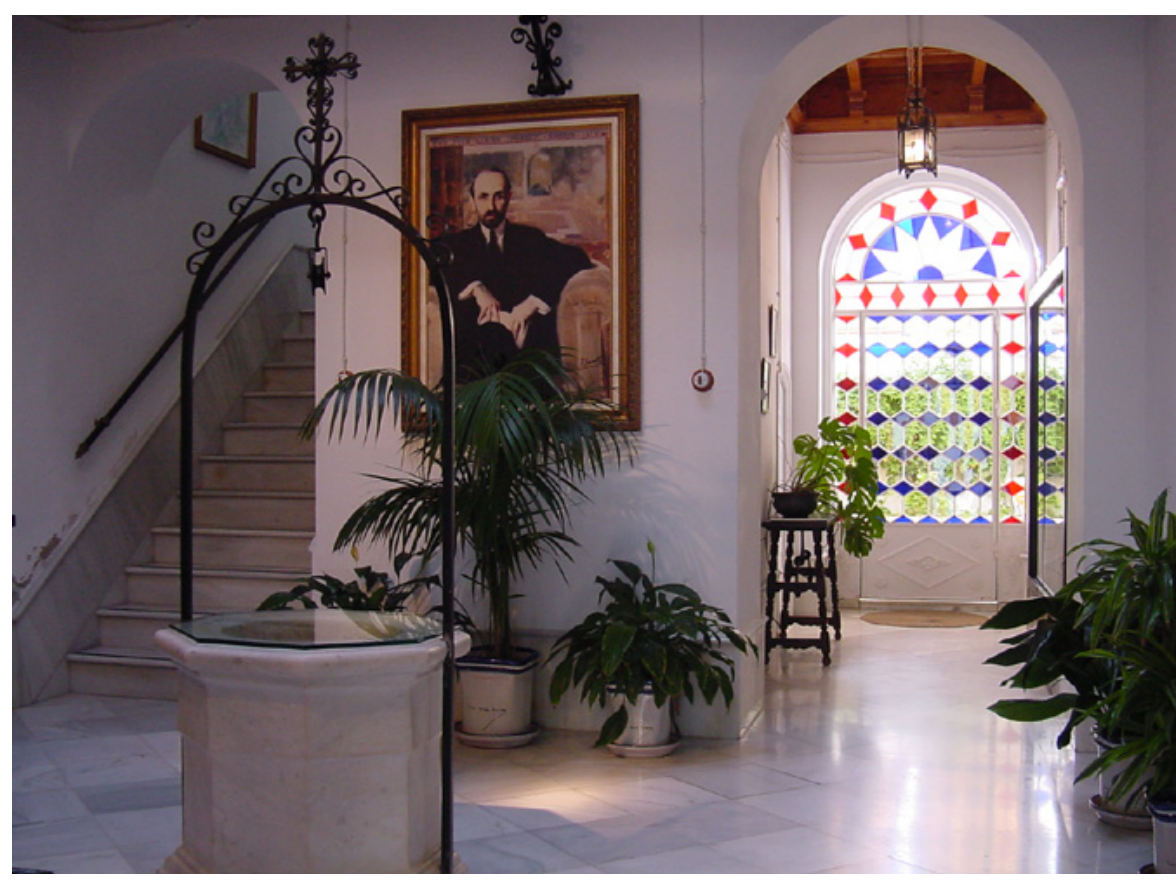

destacó como centro devocional entre la marinería. El estuario del río Tinto está considerado lugar de importancia comunitaria. En su entorno hallamos espacios protegidos como las marismas del Odiel (reserva de la Biosfera), el estero de Domingo Rubio y las lagunas de Palos y las Madres, que es paraje natural, y el Parque Nacional de Doñana, declarado Patrimonio de la Humanidad. Se trata de un paisaje de marismas de alto valor ecológico donde existe una variada avifauna acuática, invertebrados, anfibios y peces entre praderas de espartinas, almajos, verdolagas de mar y fangos. El sotobosque acoge una amplia extensión de pinos que en las últimas décadas se ha reducido para dar paso a las plantaciones de fresas.
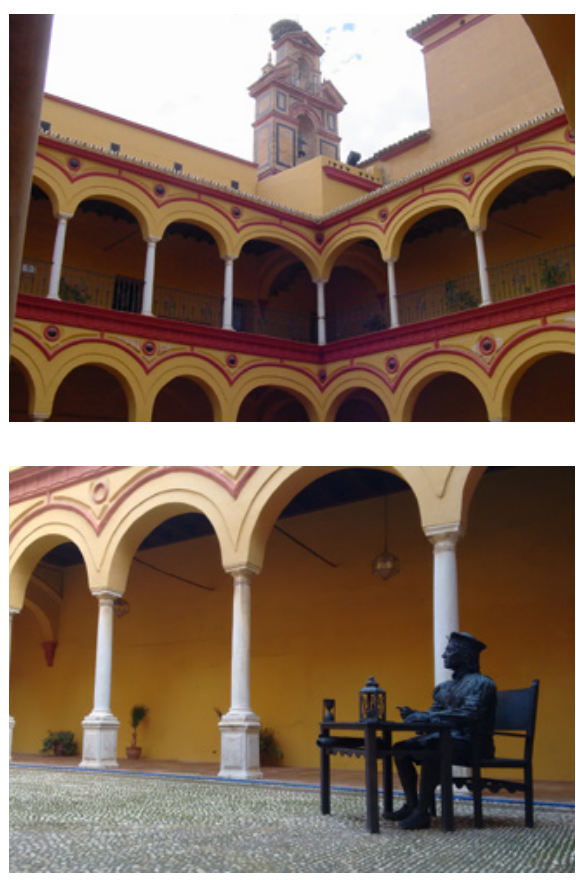

Claustro del convento de San Francisco, sede del Archivo Histórico Municipal. Moguer

Monumento al piloto Pedro Alonso Niño. Claustro de San Francisco. Moguer

Casa Museo de Zenobia y Juan Ramón Jiménez. Moguer | fotos Diego Ropero 


\section{La pesca tradicional en Huelva: de las salazones y las conserveras al congelado}

Juan José García del Hoyo, Celeste Jiménez de Madariaga | Universidad de Huelva

URL de la contribución <www.iaph.es/revistaph/index.php/revistaph/issue/view/4257>

\section{RESUMEN}

La pesca en la costa onubense ha sido una actividad que no solo puede y debe ser analizada como producción económica, sino también por las implicaciones culturales y sociales que conlleva. En este texto, mostramos una panorámica histórica de la importancia de la pesca tradicional en la provincia de Huelva y sus transformaciones hasta la actualidad. En este recorrido por la historia y las tradiciones pesqueras, nos detenemos en las artes y modos de pesca, y en otras ocupaciones vinculadas a ésta que han destacado en el litoral onubese, como las salinas y las fábricas conserveras.

Palabras claves

Congelados | Conserveras | Huelva | Pesca | Salazón | 


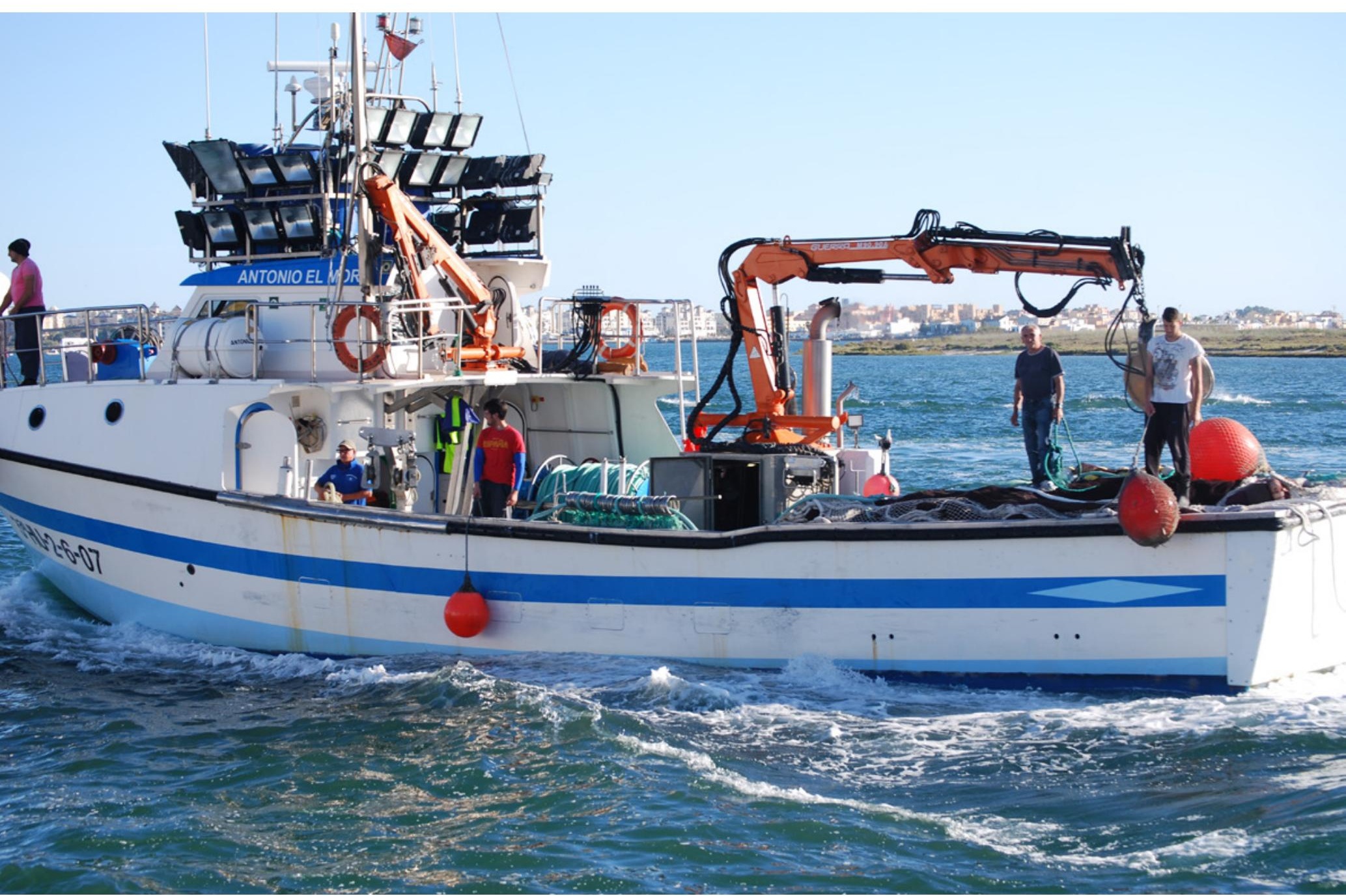

Buque de cerco de poliéster en la ría de Carreras en Isla Cristina (Huelva) | foto Celeste Jiménez de Madariaga, autora de todas las imágenes que ilustran este artículo 
La costa de la actual provincia de Huelva ha sido, desde tiempos inmemoriales, una de las zonas pesqueras más productivas de la Península Ibérica. Los grandes ríos que la acotan, las marismas y esteros, las playas abiertas $\mathrm{y}$, sobre todo, una extensa plataforma continental plagada, hasta tiempos recientes, de prados de posidonia, como citaba Miravent en 1850, la configuraban y configuran aún, a pesar de los pesares, como un lugar plenamente idóneo para el desarrollo de las actividades pesqueras y marisqueras. Yacimientos del calcolítico, como Papauvas o El Rincón, localizados en la Ría de Huelva, en cuyos vertederos abundan los restos de mariscos, y factorías de salazones romanas y anteriores, localizadas no sólo en la actual ciudad de Huelva, sino también en toda la línea costera desde Isla Canela (Ayamonte) al Cerro del Trigo en Doñana, evidencian una continuidad histórica en la que nuestros ancestros explotaban los recursos del litoral no sólo para la mera subsistencia, sino también integrándose en grandes circuitos comerciales, iniciados por fenicios y púnicos, y desarrollados plenamente durante los primeros siglos de ocupación romana. Y, además, se mantuvieron las referencias al "garum" como uno de los presentes que un monarca visigodo remitía a la corte merovingia, las descripciones bizantinas de la historia del potentado Dúnala, enriquecido con las exportaciones de salazones de sus posesiones de Saltés, o los propios textos árabes sobre dicha isla y sus producciones de salazones de sardinas que eran consumidas en Sevilla y en Córdoba, denotan una continuidad de aprovechamientos que evidencian la pervivencia de usos, técnicas, hábitos y saberes.

Barcas artesanales en el río Tinto junto a La Rábida (Palos de la Frontera, Huelva)

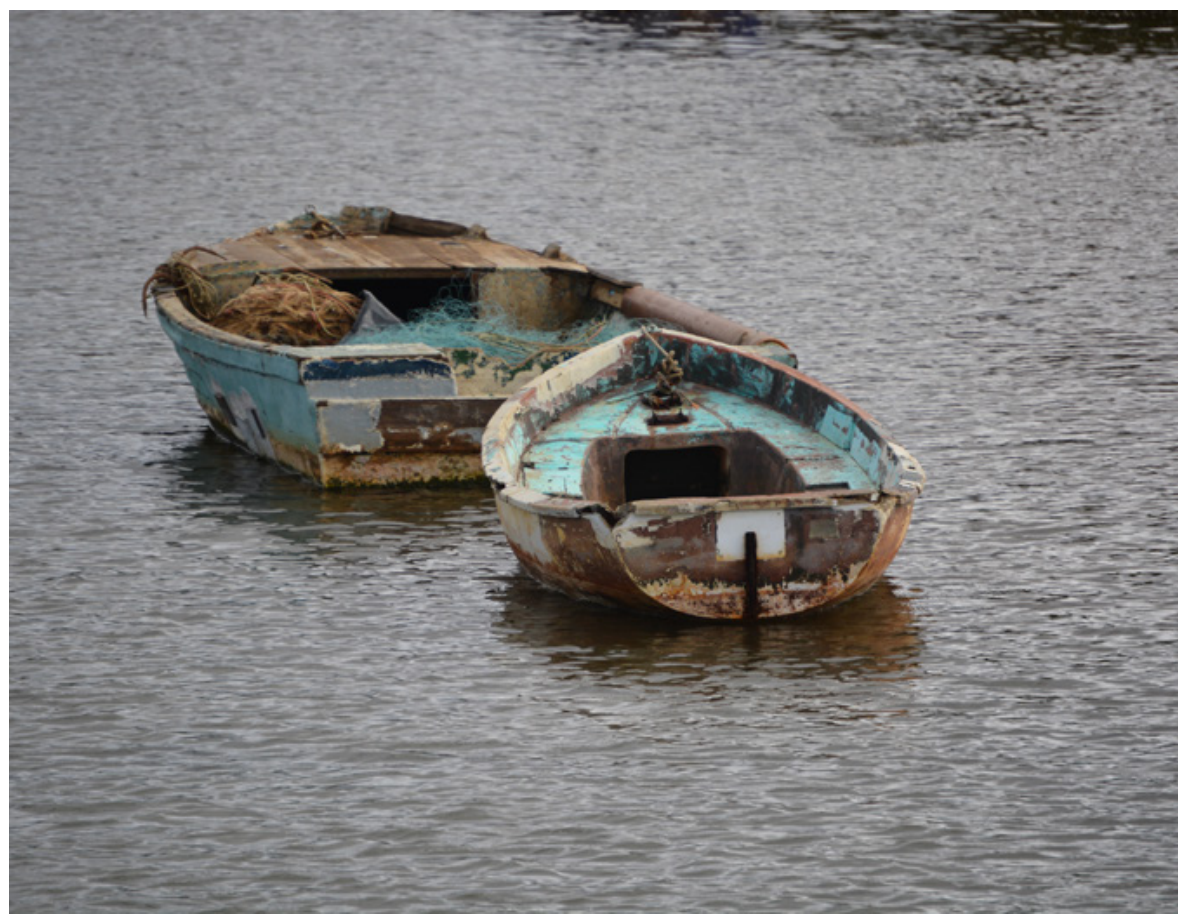




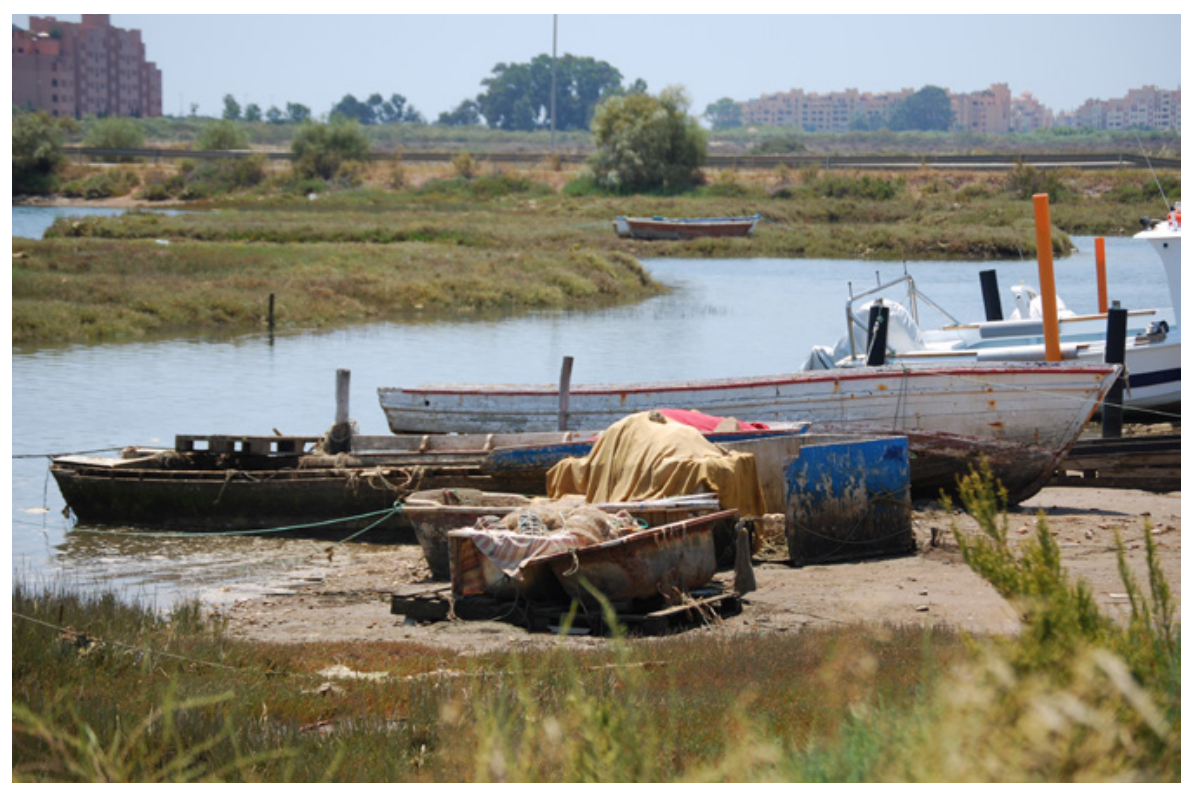

La pesca de sardinas mediante jábegas, la de atunes con almadrabas de tiro, o los sedales para corvinas, dentones y hurtas, son artes que, a pesar de su etimología árabe, ya habían sido descritas por Opiano de Apamea y Claudio Eliano en el siglo III. La presencia de estas artes está documentada en las playas de Huelva a lo largo de toda la Edad Media, y también las abundantes exportaciones que se realizaban a la costa del levante peninsular e Italia durante los siglos XV y XVI. Con posterioridad, en el siglo XVIII, se produce su etapa de mayor apogeo, bien descrita por Oyarbide, siendo la causa, incluso, de la fundación de poblaciones como Isla Cristina. Esta bonanza fue interrumpida bruscamente por los conflictos bélicos de finales del XVIII y, sobre todo, por los gravámenes sobre la sal. Aun así, todavía se usaban jábegas en los años sesenta del pasado siglo en las playas de La Antilla, El Hoyo o El Portil. Sardinas, bonitos, caballas y boquerones, junto a la abundancia de sal, permitían impulsar la producción a escala industrial de salazones y salmueras, en las chancas de las poblaciones de la costa. Junto a las jábegas y sedales, las almadrabas completaban el repertorio de las artes de pesca intensivas en capital. Se caló alguna en Ayamonte, a finales de la Edad Media, en pleitos con el conde de Niebla, y otras en las playas de Doñana o en la Barra de El Terrón. Fue precisamente en El Terrón, ya en el siglo XVIII, donde se caló la primera almadraba de Buche de Andalucía, arrendada por compañías locales al Marqués de Villafranca. En esa época, existían chancas para la salazón de atunes, no sólo en La Higuerita, sino también en Ayamonte, Huelva, en El Terrón o en El Rompido. Precisamente, esta última población, El Rompido, aparece por primera vez representada en un grabado del Diccionario de Sañez-Reguart como "lugar donde se salan los atunes".
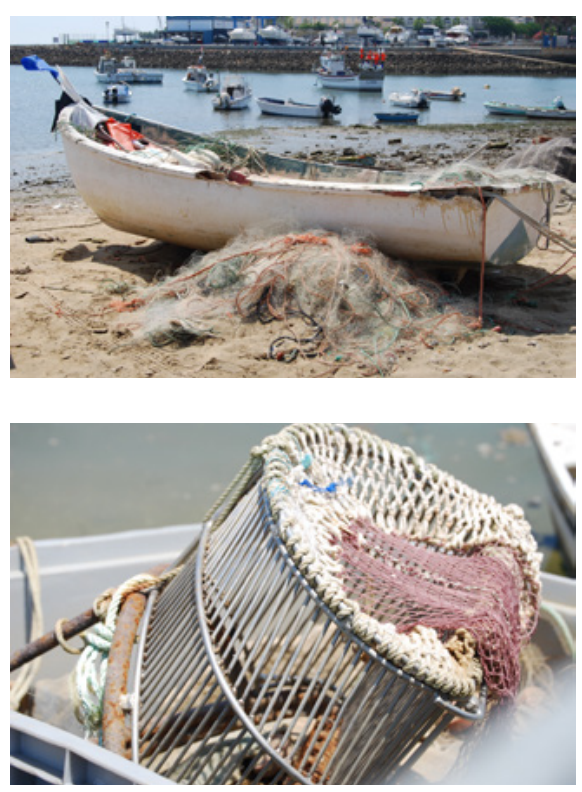

A la izquierda, pateras y botes artesanales en Punta del Moral (Ayamonte, Huelva)

Arriba, bote artesanal de trasmallo en Punta del Moral (Ayamonte, Huelva)

Abajo, moderno rastro remolcado para coquina en Punta del Moral (Ayamonte, Huelva) 
Montaña de sal en las salinas industriales de la Isla de Bacuta (Huelva)

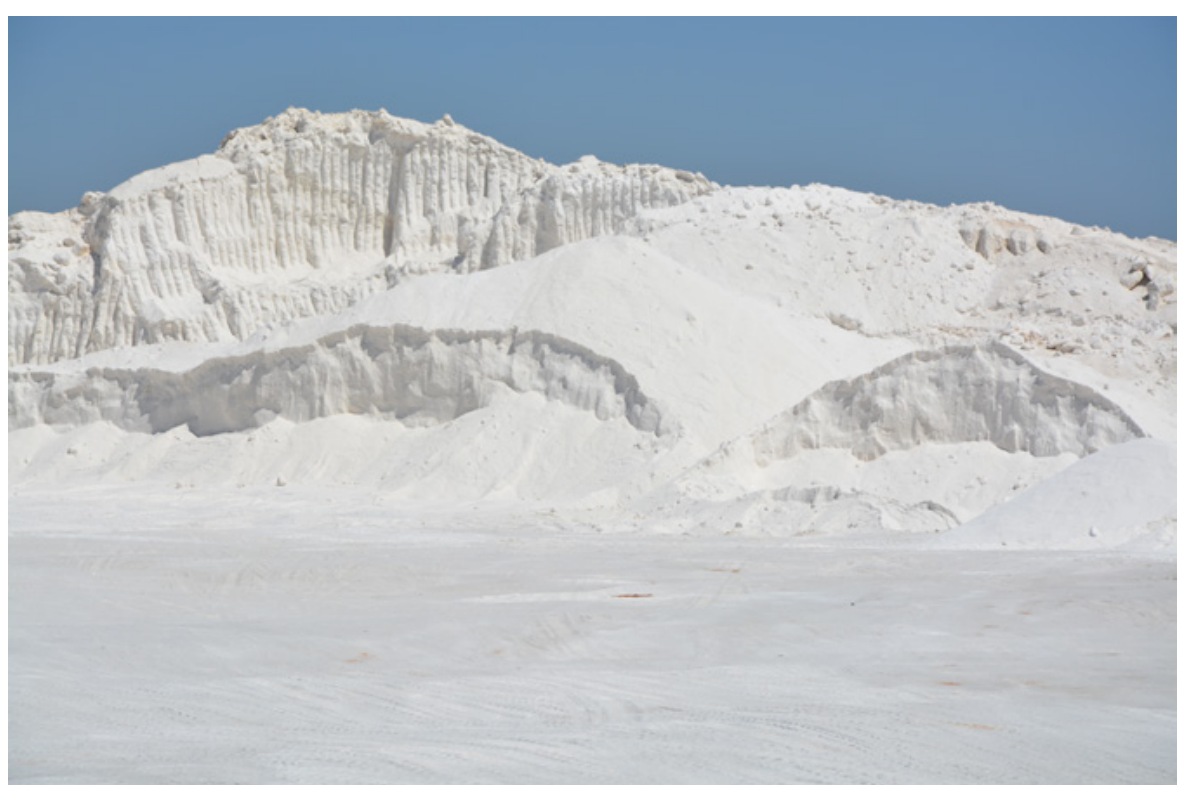

El comercio de la sal, y muchas salinas, fueron monopolio estatal y producto estancado, cuyo tributo pasó entre 1780 a 1850 de 12 rs. vn. la fanega a 50 rs. vn., provocando revueltas y motines en los pueblos de la costa que dieron al traste con el predominio moderado. Al establecerse una exención para aquellos que exportasen salazones a más de 20 leguas, relocalizó dichas actividades en los puntos más lejanos del mercado tradicional, Sevilla y su entorno. Pero no sólo hubo artes playeras y almadrabas; modestos boliches, junto a tapaesteros y lavadas de mar o de río, permitían a los no matriculados ganarse el sustento y mantener a sus familias. $Y$ es que, el privilegio de pesca a los matriculados, a cambio de servir en la Armada, sólo se limitaba a los que remaban en las barca o botes, o navegaban en faluchos, místicos o laudes. Los "terrestres", los no matriculados, tiraban de esas artes playeras, ayudados a veces por mujeres, niños y, en ocasiones de grandes capturas, por animales.

Pero también nuestros pescadores se alejaban de la costa; los marineros palermos, moguereños, leperos, ayamontinos y onubenses de los siglos XIV-XVI se dirigían a la costa africana a la captura de cazones y otros pescados de cuero, comerciando con los locales e incluso salando las capturas en tierra firme y conduciéndolas a puertos del Levante peninsular y de todo el mediterráneo occidental. Estos negocios fueron frustrados al inmiscuirse empresarios ingleses que luchaban por hacerse con el mercado ibérico de salazones y ahumados. Y es que este gran mercado -los reinos católicos peninsulares- se abastecía de diferentes fuentes: los arenques del Mar del Norte, monopolizados por las Provincias Unidas; el bacalao norteamericano, bajo control británico tras el Tratado de Utrech; y de las salazones de sar- 


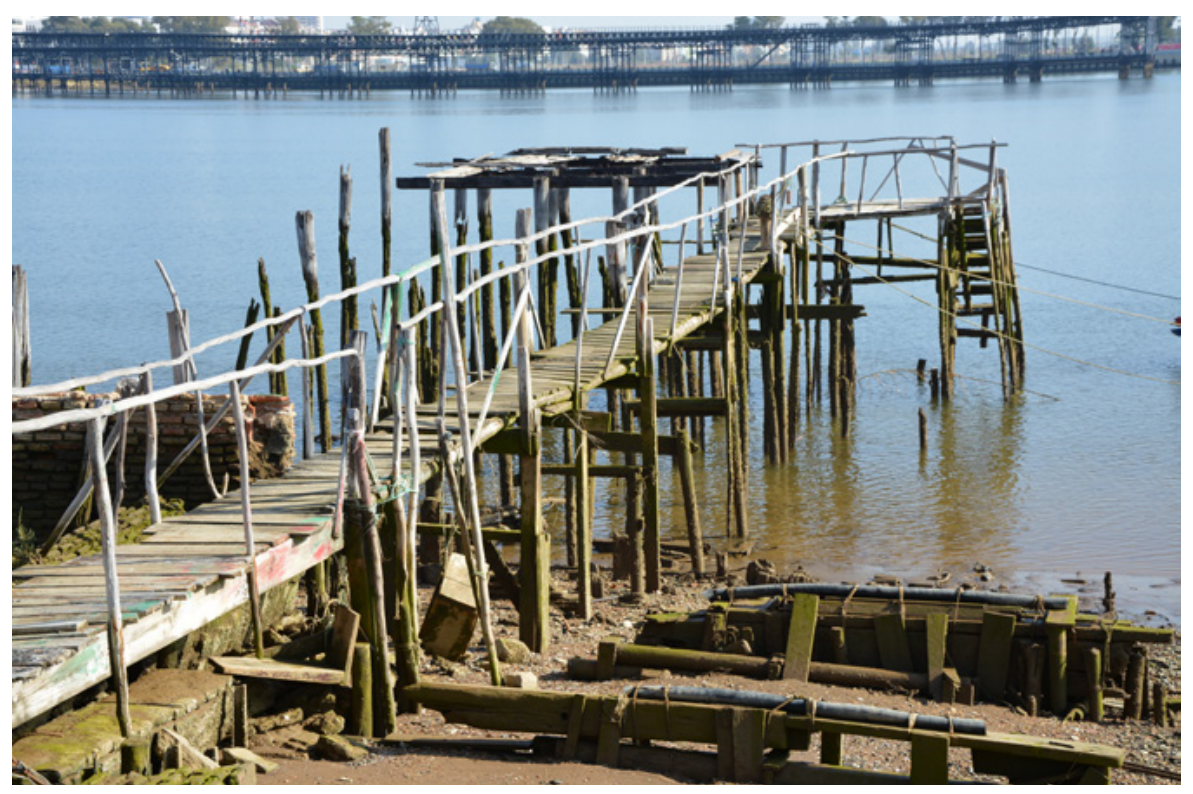

dina, atunes, bonitos, merluzas y cazones, siendo este rincón andaluz uno de los principales lugares de producción. Sin sal no podía entenderse la producción a gran escala, dado que los mercados locales no podían consumir más que una exigua porción de las potenciales capturas. Pero, una vez producidas las salazones, había que competir con las ingentes importaciones, hasta el punto de que, en periodos bélicos con Gran Bretaña, se autorizaban a buques de dicha bandera a desembarcar bacalao en puertos peninsulares para evitar el desabastecimiento y, cómo no, incluso sin autorización, a través del contrabando.

A finales del XVIII, llega la crisis: la matrícula de mar, conflictos bélicos, buques armados, marinería, deserciones y abandono de la pesca y desaliento. Si en 1776 las estimaciones de Oyarbide sitúan sólo la producción de salazones de sardina en torno a las 3.200 Tm anuales, sesenta años después los niveles de producción dados por Miravent en su "Memoria sobre las pescas..." son similares; finalizado el periodo de conflictos bélicos (17841824), se ha superado la gran crisis del sector, y sólo el tributo sobre la sal resulta una amenaza a su desarrollo.

A mediados del XIX, cuando publicaba Miravent su trabajo o cuando Berthelot salía de la Ría de Huelva en dirección a Cádiz, tratando de estudiar las pesquerías, aún predominaban las artes de tiro playero. Las almadrabas de buche, desamortizadas desde 1818, comenzaban a ser un negocio próspero; la de La Tuta, iniciada en 1828 y explotada por un grupo de empresarios isleños, la de El Portil, heredera de la del Duque, que comenzó a calarse en 1841; la de La Mojarra, que databa de 1839, junto a otras autorizadas

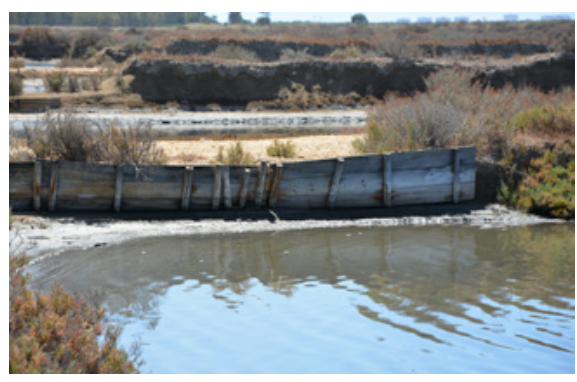

Estructuras y compuertas en la antigua salina de Bacuta (Huelva)

Embarcadero de las antiguas salinas de Bacuta (Huelva) 
a finales de siglo, totalizando siete almadrabas de atún y tres de sardinas, vinculadas al desarrollo salazonero y, sobre todo, al inicio del negocio conservero, circunscrito en su origen a la exportación de conservas de atún al mercado italiano.

Pero también se reinician las pesquerías de altura; faluchos ayamontinos y onubenses acudían a la costa de Larache cada verano para dedicarse a la pesca de la merluza con artes de cordel e incipientes palangres y, una vez capturadas, eran remitidas a Málaga, Cádiz y Sevilla para su comercialización.

Las décadas de 1860-1870 constituyen el inicio de la liberalización del sector, se elimina la exclusividad de los matriculados, facilitando la entrada de capitales, se suprime el estanco de la sal y, entonces, comienza el despegue pesquero. La liberalización de la producción y venta de la sal impulsa el negocio salinero, multiplicándose las explotaciones en las rías onubenses. Las de Bacuta, Cardeñas, El Astur, junto a otras cinco en la ría de Huelva; nueve en Isla Cristina, otras siete en Ayamonte e, incluso, una en Lepe y otra más en Almonte. Sobre 1874 se introducen los primeros galeones a remo para la pesca de sardina, que permitía a los pescadores alejarse de las playas buscando los cardúmenes que, según los documentos de la época, huían de las desembocaduras del Guadiana y del estuario del Tinto-Odiel a causa de las aguas sulfurosas que la expansión minera y las teleras provocaban. Documentos de la época nos hablan de almadrabas consumidas en Ayamonte por las aguas ácidas vertidas por la mina portuguesa de Sao Domingos, de bancos de ostras y almejas muy productivos en Huelva que

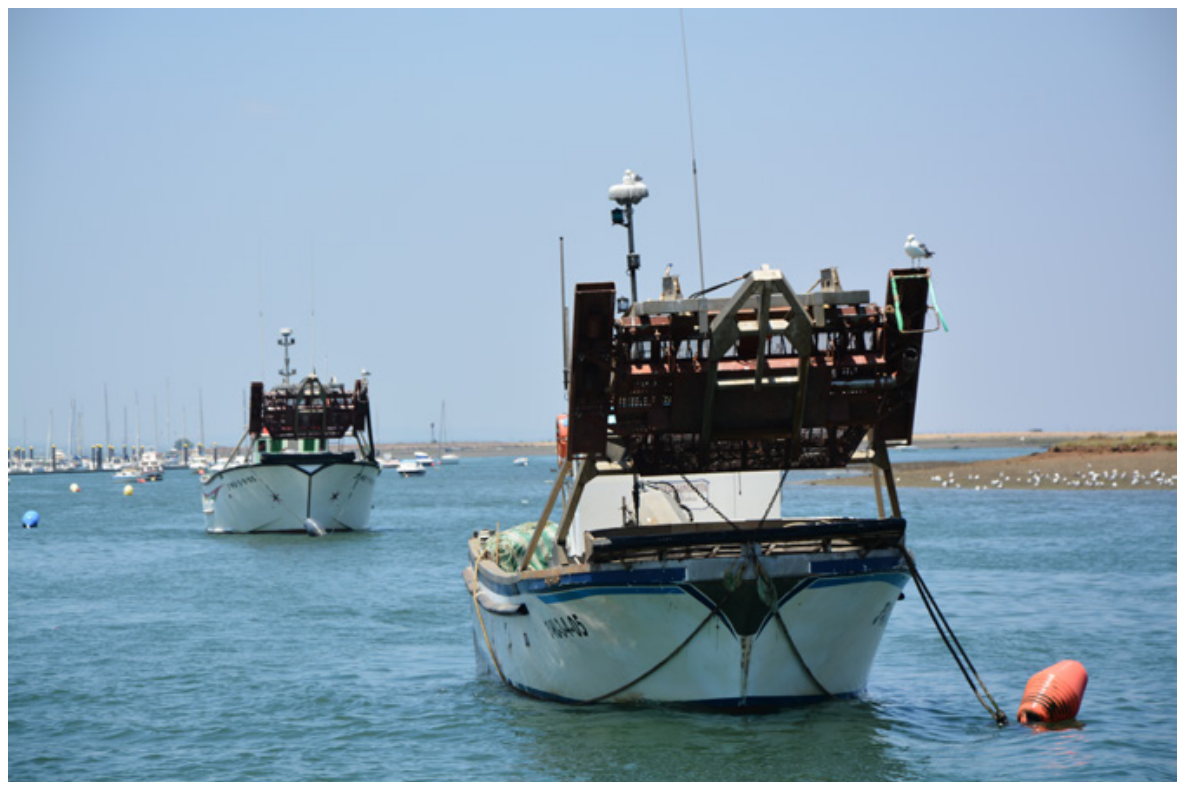


desaparecen para siempre, de sardinas que no se acercan a las playas y de atunes espantados y almadraberos que renuncian a sus concesiones. $Y$ ante esos problemas, el sector debe reconvertirse, surgiendo nuevas artes y nuevos barcos.

En Huelva capital se introducen los primeros bous o arrastres a vela en esa década de la mano de la familia Narváez, origen de lo que llegará a convertirse en la principal flota arrastrera de España a finales de los sesenta y primeros setenta. En Isla Cristina y Ayamonte y, en menor medida, Lepe y Huelva, se introducen las primeras artes de cerco -tarrafas- de origen norteamericano. En 1904 el empresario Guillermo Sundheim junto a otros onubenses adquieren dos vapores ingleses para iniciar una empresa de pesca de arrastre en el Golfo de Cádiz y las costas de Marruecos.

Los isleños y ayamontinos no se quedan atrás. En 1908 se adquiere el primer vapor para la pesca de cerco de tarrafa; en 1921 ya son cerca de 36 vapores de cerco con 1.250 TRB, pero, poco después, la sardina, huidiza, comienza uno de sus ciclos y desaparece de estas aguas. Las casi 21.000 Tm de sardina capturadas por los 36 vapores tarraferos existentes en 1923 se reducen a poco más de $400 \mathrm{Tm}$ en 1936. Crisis, cierre de fábricas, huelgas, exportación de vapores a Portugal, son las características del sector en los años anteriores a la Guerra Civil.

Las almadrabas, monopolizadas en 1928 bajo el todopoderoso Consorcio Nacional Almadrabero, comienzan a cerrar algunos de los pesqueros y fábricas, dejando sólo una almadraba operativa en la provincia desde 1940. A

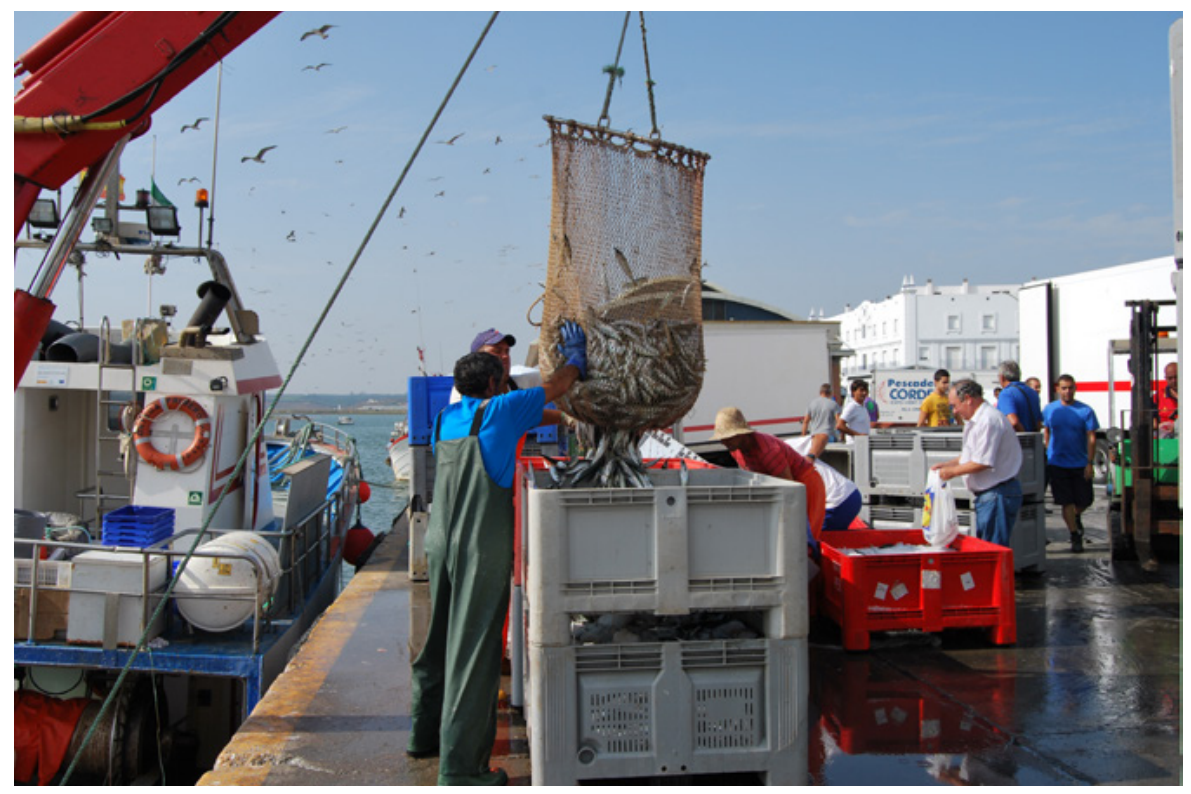


Antigua fábrica de Conservas Tejero en el estero de Domingo Rubio (Palos de la Frontera, Huelva)

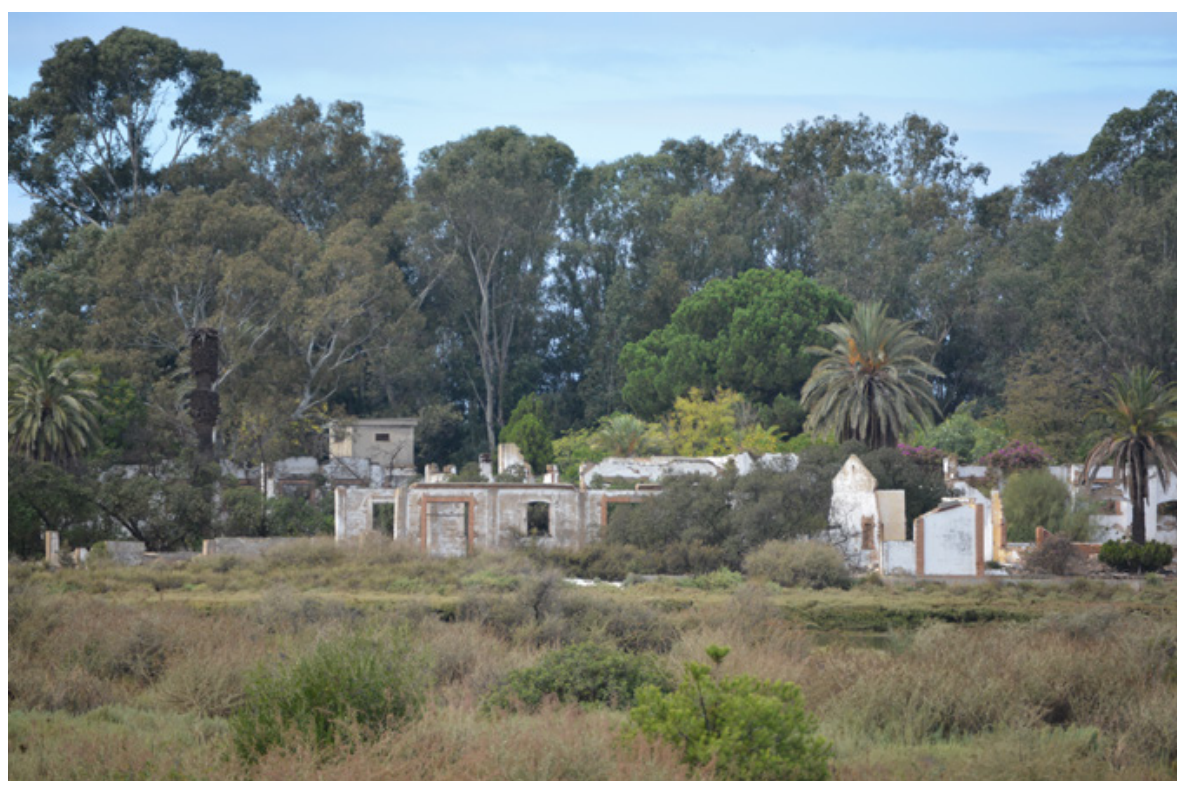

finales de los cincuenta intentó rehabilitar alguna de las que había cerrado, como Las Cabezas en Isla Cristina o La Cinta en Huelva. Pero las capturas no compensaban los esfuerzos. La almadraba de Nueva Umbría realizó su última campaña en 1965, con una captura irrisoria de tan sólo 158 atunes, cuando en 1937 había capturado 25.200 atunes.

Tras la guerra se agudiza la crisis del sector. No hay carbón, los buques apenas faenan entre 1940 y 1948, las capturas son testimoniales y sólo el sector artesanal subsiste a duras penas. Barcas de vela y botes de remo, dedicados a trasmallos y rastros, son los encargados de abastecer los mercados locales. Pero, poco a poco, se normaliza el suministro de combustibles; los vapores van siendo sustituidos por buques más modernos. En Huelva, en la capital, la flota de arrastre dedicada a la captura de crustáceos sigue su expansión; con casi un centenar de vapores y motores dedicados al arrastre en 1948, junto a un par de vapores tarraferos para cerco.

Por su parte, en Isla Cristina y Ayamonte, la sardina no regresa y las campañas posteriores a la Guerra Civil son decepcionantes. Los viejos vapores tarraferos van siendo sustituidos por modernos buques de casco de acero y motores de gasoil orientados a la captura de sardina en aguas norteafricanas, como medio para abastecer a las fábricas de conservas y salazón, que necesitan materia prima para satisfacer una demanda creciente de los mercados interiores, donde la salazón de sardinas se ha convertido en un alimento común. Se busca a la sardina, se la persigue, y la flota sardinera de altura se consolida. Es la época dorada de la pesca de sardinas, siendo Ayamonte e Isla Cristina puertos situados a la cabeza de capturas en 


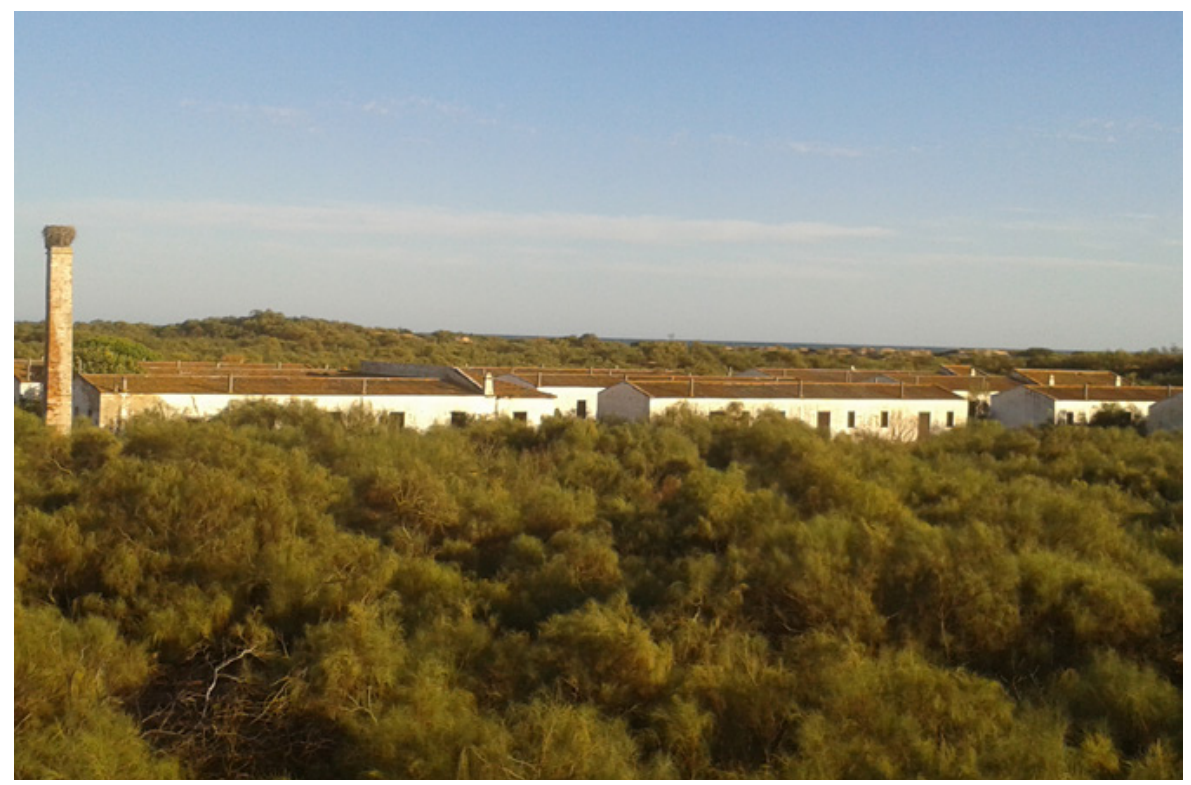

Antiguo Real de la Almadraba de Nueva Umbría (Lepe, Huelva)

España. Pero los cambios en los hábitos de consumo, con la irrupción de los productos congelados desde mediados de los sesenta, hundió la demanda de salazones e, incluso, la de conservas. De las más de ochenta fábricas existentes en 1970, tan sólo una decena subsistían en 1978, habiéndose agrupado muchos empresarios en Usisa (Unión Salazonera Isleña, SA) en Isla Cristina y Pesasur (Persca y Salazones del Suroeste, SA) en Ayamonte, empresas que aún subsisten con modernas instalaciones.

La flota artesanal de botes de vela y remo, integrada por 487 unidades y cerca de 2.000 TRB en 1940, va siendo sustituida lentamente por pequeños buques de madera dotados de motor. Son barcos polivalentes, dedicados, a veces, al arrastre, a la acedía y el langostino cerca de la costa; y en otras, al rastro remolcado, capturando chirlas, el "mechillón", cuyas capturas alcanzan niveles extraordinarios a finales de la década de 1960, con más de $30.000 \mathrm{Tm}$ de bivalvo que se convierte en un producto habitual en los mercados del centro de la Península. Pero, sorpresivamente, en 1969, el caladero se hunde, y las capturas son nulas en 1971 ¿Qué había pasado? ¿Sobreexplotación? Eso indicaban algunos trabajos de la época. Pero no, la puesta en marcha del polo industrial en Huelva cobró su peaje; doscientos barcos se pudrían en la Isla de Saltés o en los esteros de Carreras. La pesca en Huelva parecía estar condenada siempre a ser la hermana pobre de las actividades económicas.

Mientras, los vapores arrastreros de Huelva, dedicados a la captura de crustáceos en aguas marroquíes y del Golfo de Cádiz, comienzan a dar origen a un segmento de flota. El 1964 el pesquero Onuba, que había sido equipado 
con cámaras de congelación, realiza una campaña exploratoria en aguas de Mauritania y Senegal. Es el primer buque de arrastre congelador de Huelva, segmento que comienza una rápida expansión hasta alcanzar unas 250 unidades en 1978 desplazando 81.982 TRB y que operaban en todo el litoral africano, desde Mozambique a Mauritania. Pero la extensión de las aguas territoriales y las ZEE (Zona Económica Exclusiva) a partir de 1978, limitó drásticamente la actividad, reduciéndose progresivamente el número de unidades y comenzando un proceso de exportación de buques a empresas pesqueras conjuntas y sociedades mixtas. En la actualidad sólo 33 buques con bandera española siguen manteniendo esta actividad.

Ya no hay flotas de altura -se dejó de faenar en el caladero marroquí- y la flota congeladora es testimonial. La pesca subastada, las capturas, es semejante en volumen a la de 1915, pero la flota es mucho mayor y de mayor potencia. Ya no se construyen buques de madera; el último se botó en 2000. Pero, es más, si en 1987 tan sólo había 29 barcos de poliéster frente a 548 de madera, en la actualidad hay 342 de poliéster y sólo 50 de madera que van curso a su desaparición, y con ellos una actividad inmemorial, la carpintería de ribera, cuyas principales empresas ya han cerrado.

Con esta breve trayectoria histórica de lo que ha sido la pesca en la costa de Huelva, se vislumbra la importancia que esta actividad ha tenido y que aún mantiene, a pesar del descenso en el nivel de capturas y flota. Pero la importancia de la pesca en las sociedades locales onubenses no solo se mide en productividad económica. La pesca implica un modo de vida, unas formas de relaciones laborales que influyen en la cotidianidad social (asociacionismo, cooperación, cofradías), familiar y vecinal; unos conocimientos y saberes que, por lo general, se trasmiten de generación en generación; labores y trabajos vinculados al hecho de pescar (rederos, estibadores, mujeres que trabajan en fábricas de conservas y salazones, salinas, etc.); poblaciones con un urbanismo de cara al mar, con edificios e instalaciones que les dan una fisonomía característica (muelles, lonjas, tinglados, embarcaderos, astilleros); barcos (de todas las tipologías), botes, pateras de ría; y un sinfín de utensilios, aparejos e instrumentos cuyo uso requiere de habilidades y el aprendizaje casi siempre informal. Hablamos, en definitiva, de la cultura de la pesca, una tradición que, como todas las tradiciones, se ha ido transformando y adaptando con los avatares de la política, la economía y la incorporación de las nuevas tecnologías. Pero, aun pasando de las salazones a las conservas, y de éstas al congelado y a nuevas presentaciones comerciales, la pesca destaca como seña de identidad de estos pueblos de la propia provincia de Huelva y como expresión de su patrimonio cultural. 


\section{BIBLIOGRAFÍA}

- BERTHELOT, S. (1856) Exploración de la costa meridional de España. Cádiz: Imprenta y Litografía de la Revista Médica, 1856

- GARCíA DEL HOYO, J. J. (2006) Economía Clásica, Liberalización Pesquera y Sobreexplotación en Andalucía. En IFAPA (ed.) Historia de la Pesca en el ámbito del Estrecho. Sevilla: Consejería de Agricultura y Pesca de la Junta de Andalucía, vol. II, 2006, pp. 961-1001

- garcía del hOYO, J. J. (2009) El desarrollo de las estadísticas del sector pesquero durante los siglos XVIII y XIX. En BASULTO SANTOS, J.; GARCÍA DEL HOYO, J. J. (ed.) Historia de la Probabilidad y Estadística (IV). Huelva: Servicio de Publicaciones de la Universidad de Huelva, 2009, pp. 265-310

- JIMÉNEZ DE MADARIAGA, C.; DELGADO MÉNDEZ, A. (2016) Marismas del Odiel: usos y recursos tradicionales. En CAMPOS CARRASCO, J. M. (dir.) El patrimonio histórico y cultural en el paraje natural Marismas del Odiel. Un enfoque diacrónico y transdisciplinar. Huelva: Servicio de Publicaciones de la Universidad de Huelva y Autoridad Portuaria de Huelva, 2016, pp. 468-490

- JIMÉNEZ DE MADARIAGA, C.; GARCÍA DEL HOYO, J. J. (2014) Cultura de la Pesca, Patrimonio y Turismo. En GARCÍA DEL HOYO, J. J. (ed.) Cultura, Mercado y Gestión de la Pesca Artesanal en el Golfo de Cádiz. Huelva: Universidad de Huelva, 2014, pp. 107-131

- JIMÉNEZ DE MADARIAGA, C.; GARCÍA DEL HOYO, J. J. (2016) Cultura y Pesca. Actas de las Jornadas de Patrimonio Cultural Pesquero. Huelva: Servicio de Publicaciones de la Universidad de Huelva, 2016

- MIRAVENT y SOLER, J. (1850) Memoria sobre las pescas que se cultivan en las costas de España, desde el cabo San Vicente hasta el Estrecho de Gibraltar. Huelva: Imprenta Reyes, 1850

- OYARBIDE, J. M. (1776) Informe a la Real Sociedad Patriótica de Sevilla. Obra manuscrita. Archivo Histórico de Sevilla. Papeles del Conde del Águila, tomo 61, número 4. Sevilla

- RODRÍGUEZ SANTAMARÍA, B. (1923) Diccionario de artes de pesca de España y sus posesiones. Madrid: Imprenta de los sucesores de Rivadeneyra, 1923

- SAÑEZ-REGUART, A. (1791-1795) Diccionario Histórico de los Artes de la Pesca Nacional. Madrid: Imprenta de la Viuda de D. Joaquín Ibarra, 1791-1795 


\section{Los molinos mareales del litoral onubense}

Patxi Serveto i Aguiló | Asociación Amigos de los molinos mareales del Litoral

Onubense

Diego Vázquez Capelo | Platalea, Sociedad Cooperativa Andaluza

URL de la contribución <www.iaph.es/revistaph/index.php/revistaph/issue/view/4261>

\section{RESUMEN}

La invención de los molinos hidráulicos revolucionó el desarrollo de la humanidad, al facilitar la utilización de los recursos naturales para su alimentación. Los molinos instalados en la costa fueron una aplicación ingeniosa a las mareas; los molinos mareales constituyeron una potente industria en el litoral atlántico europeo.

El molino mareal más antiguo del continente data del siglo VII d. de C., difundiéndose a lo largo de la Edad Media y durante los siglos XVII y XVIII. En el sudoeste peninsular se instalaron molinos de agua salada a partir del siglo XIII, tras su conquista a los musulmanes. En Huelva, en las marismas de las desembocaduras de sus ríos, llegaron a existir más de cincuenta. Con la llegada de la revolución industrial comenzó su lenta agonía, debida a la pérdida de rentabilidad y competitividad a lo largo de los siglos XIX y XX.

Uno de los molinos mareales onubenses más singulares y de mayor envergadura fue EI Pintado (Ayamonte); adquirido mediado el siglo XVIII, fue reconstruido y funcionó hasta 1946. Su historia expresa el vínculo existente entre las poblaciones costeras y el aprovechamiento de los recursos naturales, así como su vinculación con el comercio con América.

La reconstrucción del molino mareal El Pintado, y su rehabilitación como centro de interpretación del patrimonio cultural y natural, como ecomuseo, ha constituido un hito en la divulgación y puesta en valor de los molinos mareales de Huelva. Actualmente, este ecomuseo constituye un equipamiento de la Red de Espacios Naturales Protegidos de Andalucía.

\section{Palabras clave}

Costa occidental | Ecomuseos | Huelva | Interpretación del patrimonio | Molino de mareas | 


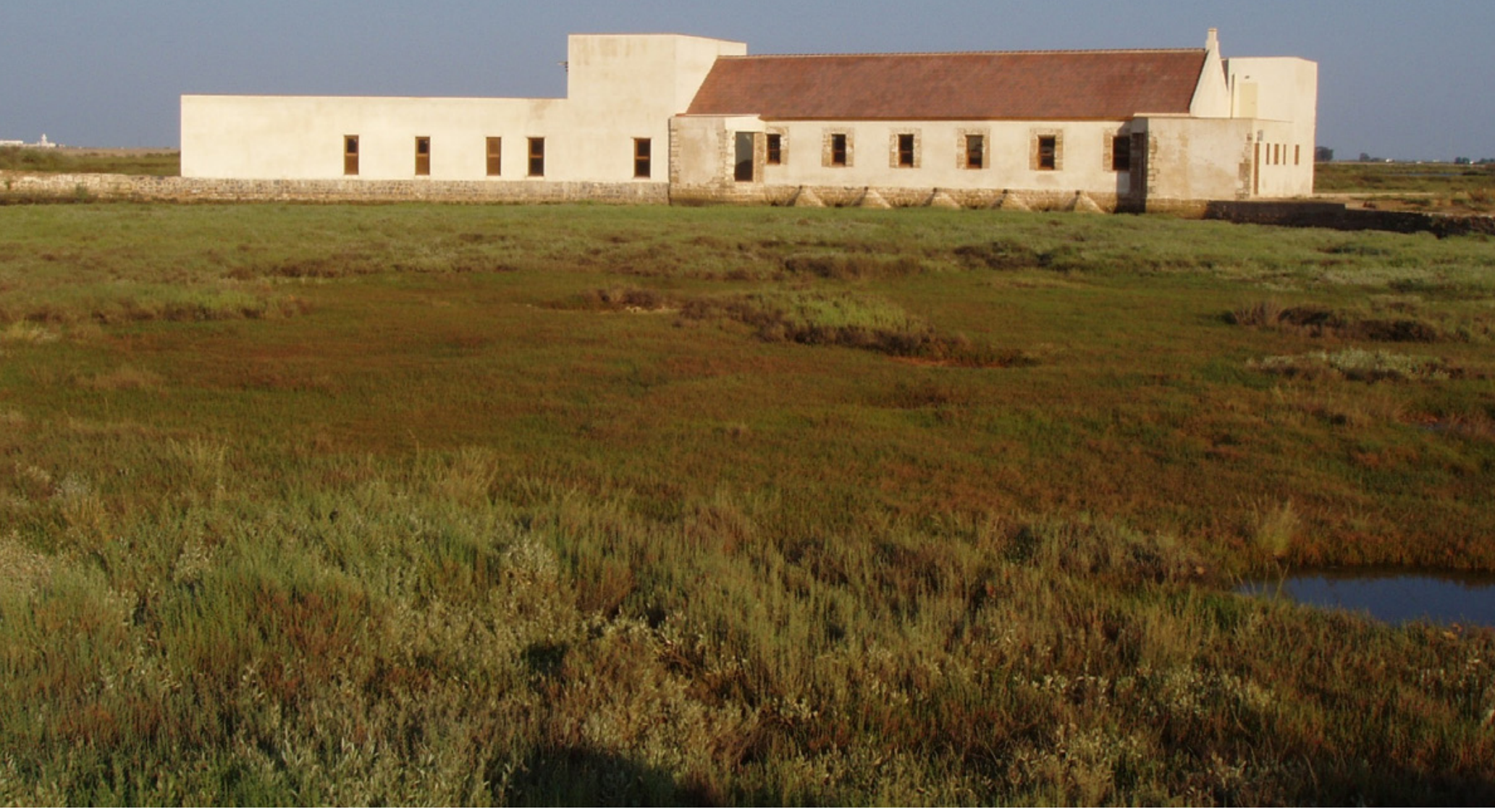

Molino mareal El Pintado reconstruido | foto Patxi Serveto (Ayamonte, 2007) 
“¡Qué ilusión cuando entró en el corral por vez primera, Platero! Era marismeño y con él venía a mí un cúmulo de fuerza, de vivacidad, de alegría. ¡Qué bonito era! Todas las mañanas, muy temprano, me iba con él ribera abajo y galopaba por las marismas levantando las bandadas de grajos que merodeaban por los molinos cerrados. Luego, subía por la carretera y entraba, en un duro y cerrado trote corto, por la calle Nueva".

(Juan Ramón Jiménez; Platero y yo, 1917: "Almirante" 144).

Distribución de los molinos mareales en el litoral atlántico europeo | fuente AZURMENDI PÉREZ; GÓMEZ CARBALLO; GRUPO ENTORNO; Ecomuseo del Molino El Pintado, 2009

\section{LOS MOLINOS MAREALES; IMPORTANCIA HISTÓRICA EN EUROPA}

La invención de los molinos hidráulicos constituyó una auténtica revolución en el desarrollo de la humanidad al ampliar nuestra capacidad de utilización de los recursos naturales, por ejemplo la molienda para la obtención de harina, vital para nuestra alimentación.

Los molinos instalados en la costa fueron una aplicación ingeniosa al fenómeno de las mareas, aprovechando su flujo para rotar las piedras molineras; los molinos mareales constituyeron una potente industria, llegando a existir a lo largo de la historia más del millar en el litoral atlántico europeo.

El molino mareal más antiguo conocido hasta la fecha en Europa data del siglo VII d. de C. (Irlanda del Norte). A lo largo de la Edad Media se difun-

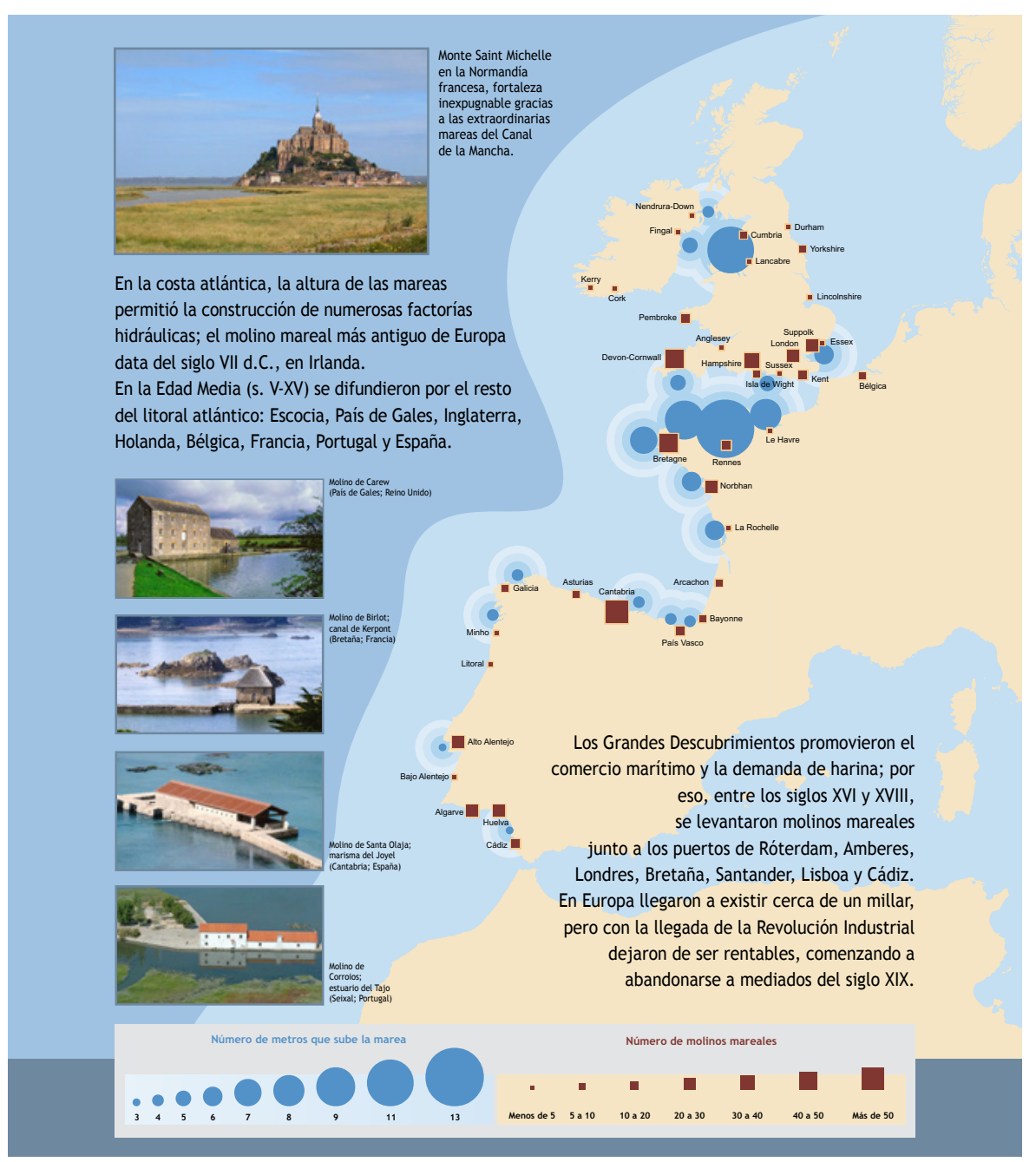




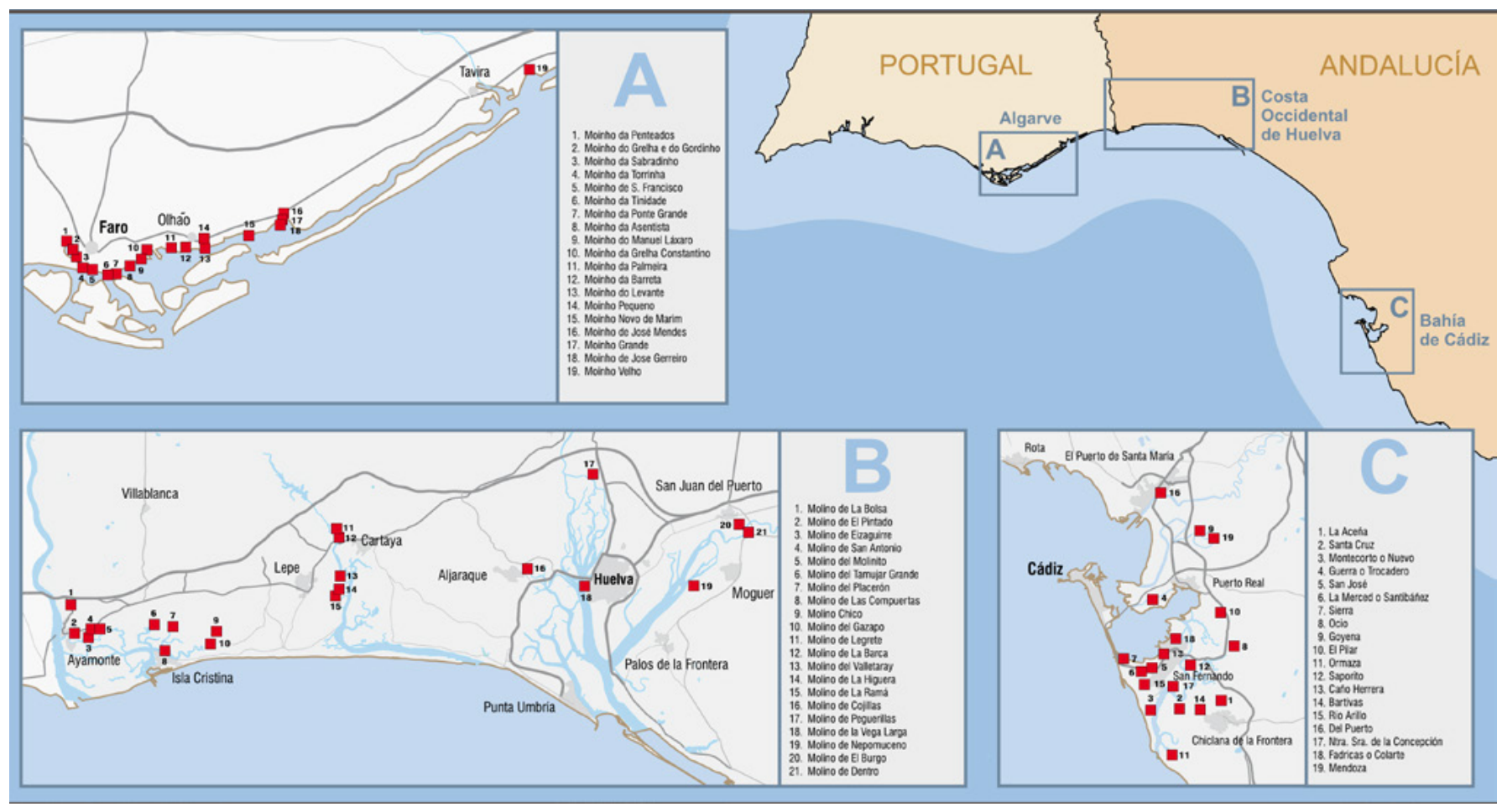

Localización de los molinos más representativos del sudoeste peninsular | fuente SERVETO AGUILÓ; GRUPO ENTORNO; Ecomuseo del Molino El

dieron por el litoral Atlántico (Escocia, País de Gales, Inglaterra, Holanda, Pintado, 2009 Bélgica, Francia, Portugal y España), continuando durante los siglos XVII y XVIII.

En el sudoeste peninsular se instalaron molinos de agua salada a partir del siglo XIII, tras su conquista a los musulmanes por parte de lusos y castellanoleoneses, ya que gran parte del arco Atlántico, desde Faro hasta Cádiz, presenta unas características geomorfológicas idóneas para el aprovechamiento de las mareas debido a su amplitud, y al complejo sistema de rías, estuarios y marismas, llegando a existir bastantes más de la centena.

En el litoral Atlántico andaluz, los molinos se extendieron en Huelva en las marismas de las desembocaduras de sus ríos, mientras que en Cádiz lo hicieron alrededor de su metrópolis, importante por su actividad comercial con Las Indias, llegando a funcionar más de 20; con su harina se elaboraban unas galletas especiales (biscuits) para avituallar las naves que realizaban las travesías transoceánicas.

Con la llegada de la revolución industrial comenzó su lenta agonía, debido a la pérdida de rentabilidad y competitividad; mientras algunos fueron reconvertidos para diversas actividades, otros sufrieron el abandono y destrucción a lo largo de los siglos XIX y XX.

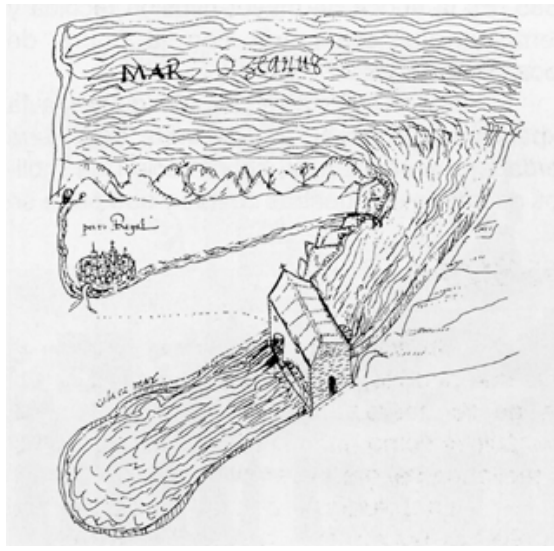

Primera representación conocida de un molino mareal en España (Lobato del Canto, F. [c.15471585] Puerto Real | fuente AZURMENDI PÉREZ; GÓMEZ CARBALLO; MARCHÁN FIZ et ál., 2005: 20 


\section{LOS MOLINOS MAREALES DEL LITORAL ONUBENSE}

A comienzos del siglo XV, se citan en Gibraleón y Moguer (1436); y, comenzando el XVI, funcionaba al menos uno en Ayamonte. En este periodo de expansión demográfica y desarrollo, estos molinos aparecen en las principales urbes, centros administrativos, nobiliarios y políticos -Ayamonte, Gibraleón y Moguer-, por entonces frontera occidental del reino de Sevilla. Fueron propiedad bien de órdenes religiosas, bien de los señores de las villas -condados de Niebla y Gibraleón, y marquesado de Ayamonte-, aunque se arrendaban a particulares. No se privatizaron hasta los siglos XVIII y XIX.

1

Se denominaba comúnmente "molino de pan moler" al dedicado a la molienda de los diferentes cereales destinados a la elaboración de pan, independientemente de la fuerza motriz que los impulsara: "Un molino de pan moler, todo de cantería de Puerto Real, con su pieza principal de techumbre de tijera, cana y redoblón de Sevilla..." Descripción realizada por Manuel Rivero "El Pintado" de su molino en el aprecio de sus bienes fechado en 1767 (MORENO ALONSO, 2000: 73).
El Molino de la Vega Larga (edificio blanco del extremo superior-derecho) a comienzos del siglo $\mathrm{XX}$, del que tomó nombre una popular barriada de Huelva | fuente Huelva Información y Autoridad

Portuaria de Huelva [2008] 100 postales antiguas de Huelva
Finalizando el siglo XVI ya se contabilizaban once molinos en Ayamonte, sobrepasando el medio centenar los existentes en el litoral onubense. Probablemente pudieran aparecer algunos molinos de mar de pan moler ${ }^{1}$ más, de seguir investigando en los archivos municipales; como fue el caso del molino mareal hallado en San Juan del Puerto en 2013.

Tras la crisis del siglo XVII, Europa vive un desarrollo demográfico, social y económico que impulsa un incipiente desarrollo industrial, en el que los molinos jugaron un importante papel en el abastecimiento de productos básicos como la harina y el aceite; en el siglo XVIII se intensificó la actividad en el litoral onubense hasta que, a finales del siglo XIX, decayó por la competencia de procesos productivos más rentables. Platero ya vio los molinos de Moguer cerrados.

Concluida la Guerra Civil se produjo un breve resurgir, clandestino, de la actividad debido a la escasez de harina. Por último, algunas estructuras de

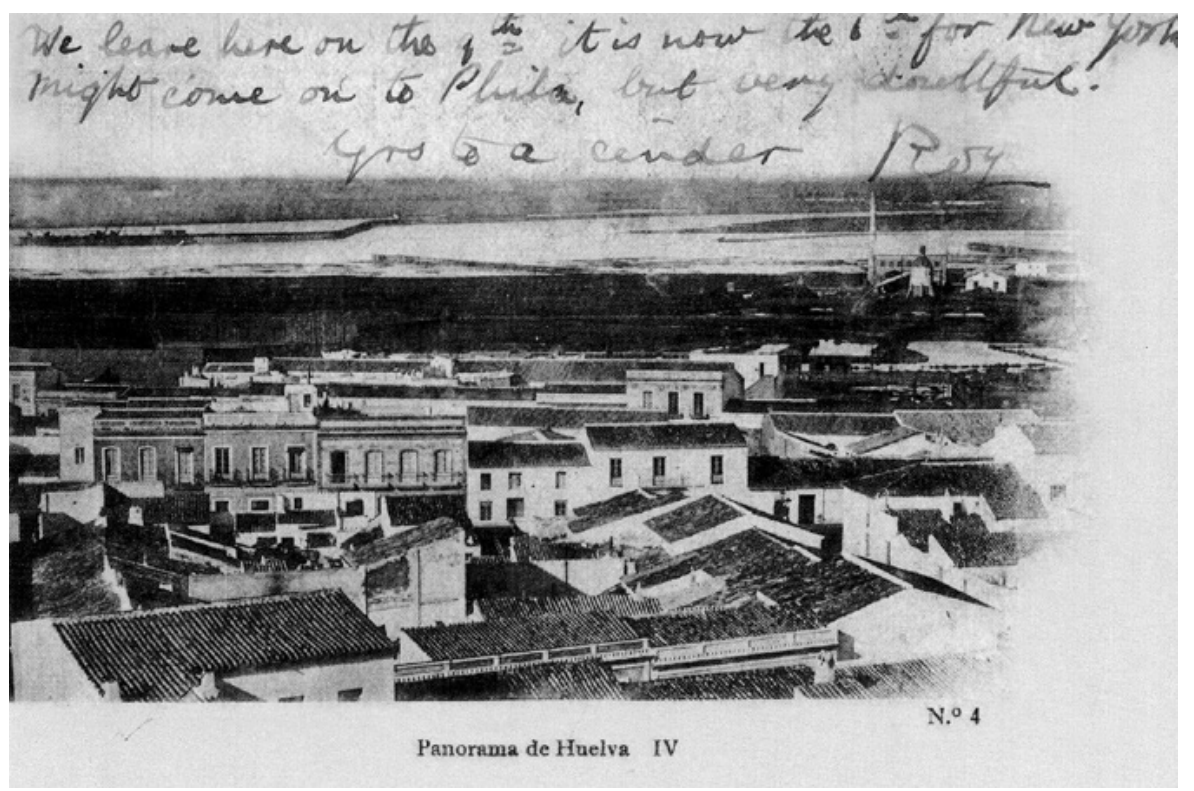


Ios molinos se aprovecharon para los "pesqueros"; pero a finales de siglo, la mayoría estaban ya ruinosos, si no desaparecidos, claro ejemplo de patrimonio cultural industrial disperso.

Este abandono contribuyó al cambio que se estaba produciendo en la relación de las poblaciones costeras con sus marismas, basada ancestralmente en el aprovechamiento sostenible de los recursos naturales -molinos mareales, salinas, pesca, marisqueo y ganadería-, aflorando tan sólo los "inconvenientes" al decaer este: insalubridad, improductividad, aislamiento...

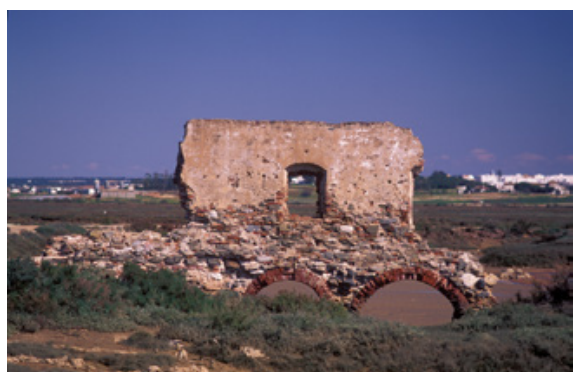

Molino de Valletaray en el río Piedras | foto Patxi Serveto (Lepe, 2006)

\section{EL MOLINO MAREAL EL PINTADO: RECONSTRUCCIÓN Y REHABILITACIÓN COMO CENTRO DE INTERPRETACIÓN DEL PATRIMONIO}

Uno de los molinos mareales onubenses más singulares fue El Pintado (Ayamonte). Adquirido mediado el siglo XVIII, entre la llustración y la Revolución Industrial, por el indiano y mecenas ayamontino Manuel Rivero González, El Pintado (1697-1780), quien lo reconstruyó renombrándolo como San José; funcionó hasta mediado el siglo XX (1946).

Desde el punto de vista fabril fue uno de los molinos de mayor envergadura del litoral de Huelva, con seis muelas. Arquitectónicamente se trata de una edificación proyectada en Cádiz, en la que destaca el empleo de piedra ostionera, caliza marina traída en sus naves desde Puerto Real, como elemento tanto de basamento como decorativo.

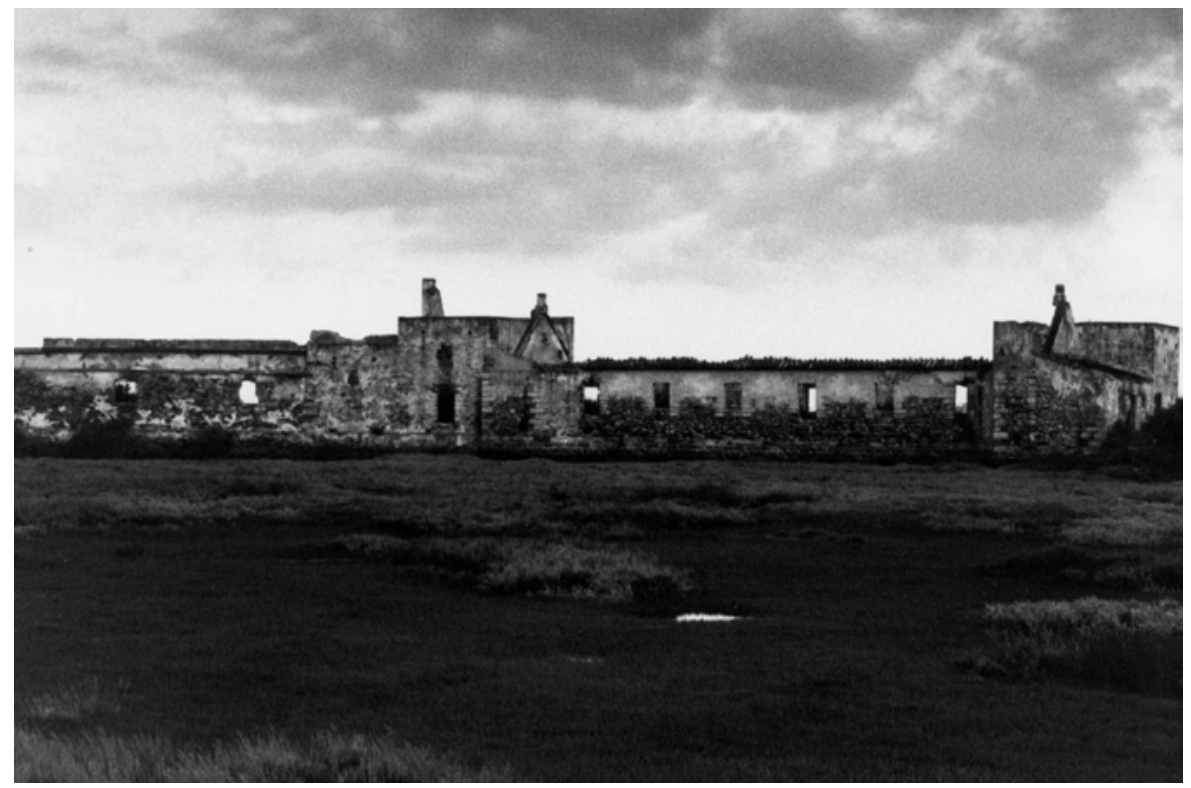


Biodiversidad de avifauna en el pesquero de las marismas del río Guadiana y ría Carreras | foto Patxi Serveto (Isla Cristina, 1990)

El Molino mareal El Pintado una vez reconstruido en su marisma | foto Toño Méndez (Ayamonte, c. 2016)
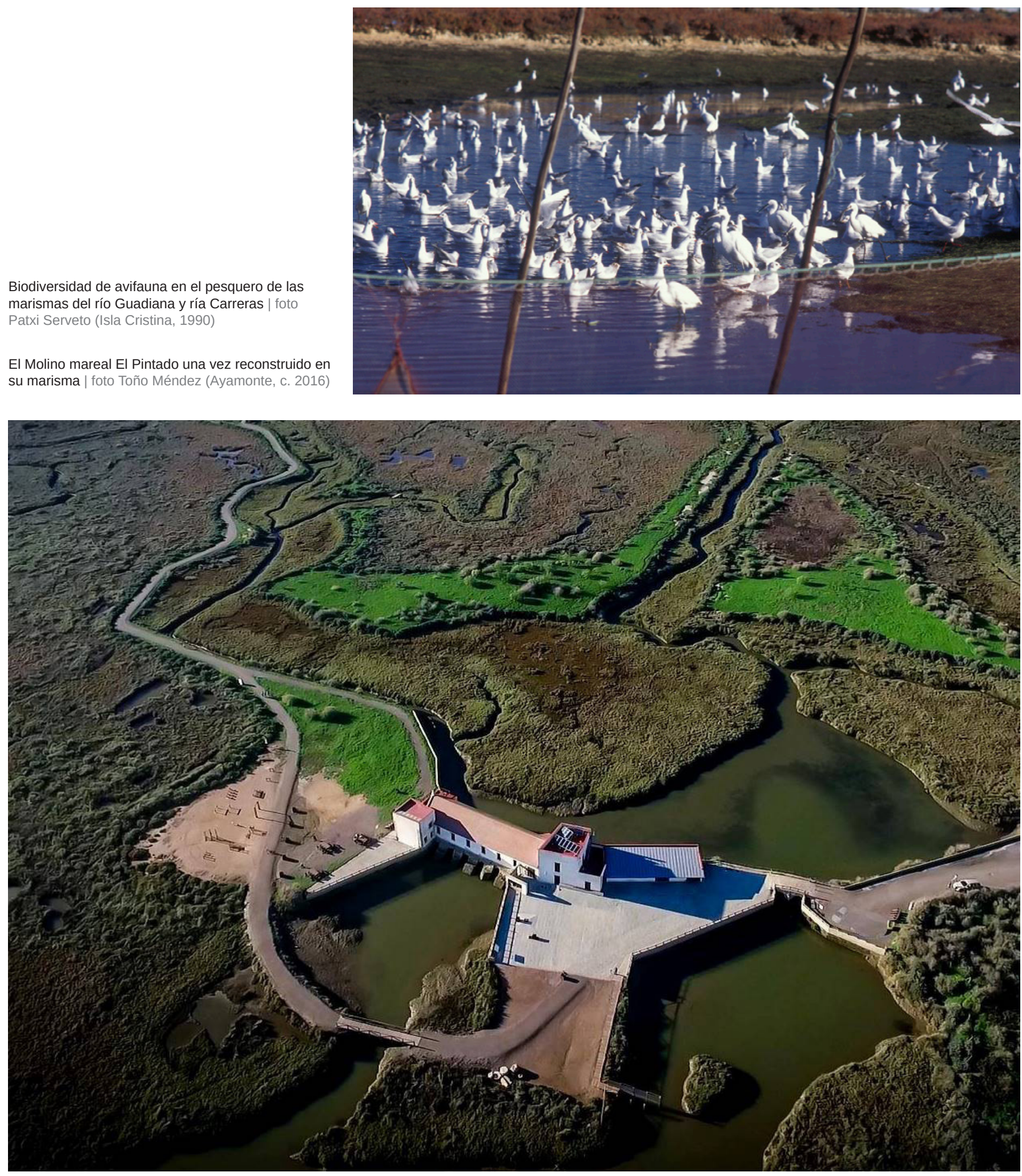


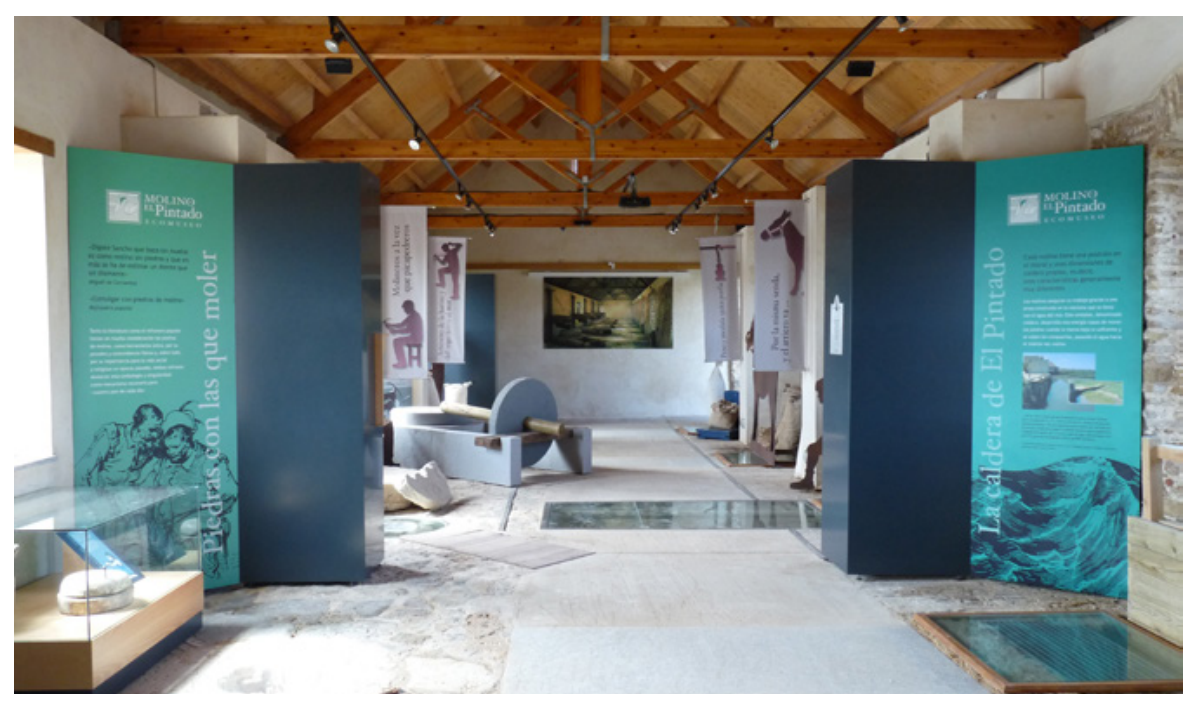

Su historia no solo expresa el vínculo existente entre las poblaciones costeras y los ámbitos marismeños como espacios de aprovechamiento de recursos naturales y de comunicación, sino que pone de relieve la vinculación del lugar con el mundo colonial de América.

La reconstrucción del molino mareal El Pintado (2007), y su rehabilitación como centro de interpretación del patrimonio cultural y natural para la creación de un ecomuseo² (2009), constituyó uno de los fines más emblemáticos que se propuso la Asociación de Amigos de los Molinos Mareales del Litoral Onubense, creada en Ayamonte en 1996 y dedicada al estudio, divulgación y puesta en valor de los molinos mareales de Huelva.

Paralelamente, en 2004 la Asociación solicitó a la Consejería de Cultura la inscripción, como bienes de catalogación general de manera colectiva, de los molinos mareales del litoral onubense en el Catálogo General del Patrimonio Histórico Andaluz, produciéndose en 2010.

Actualmente, el Ecomuseo del Molino Mareal El Pintado constituye un equipamiento de la Red de Espacios Naturales Protegidos de Andalucía, actuando como recepción del visitante, punto de información y ecomuseo del Paraje Natural Marismas de Isla Cristina; su gestión, mediante concesión administrativa, corresponde a Platalea XXI. Además de las actividades propias de la atención al visitante, desde el ecomuseo se desarrolla un amplio programa de dinamización en el que destacan:

1. Actividades educativas enmarcadas en los programas Naturaleza y Tú y Naturaleza para todos, ofertados por la Consejería de Medio Ambiente y Ordenación del Territorio.
Exhibición interpretativa en la sala de molienda del ecomuseo El Pintado | foto Patxi Serveto (Ayamonte, 2010)

$$
2
$$

Equipamiento destinado a revelar al visitante elementos del patrimonio ambiental (elementos geológicos, especies de flora y fauna, hábitat o paisajes) y cultural (actividades, construcciones o expresiones humanas como comportamientos y tradiciones, etc.) del espacio natural y su entorno (CONSEJERÍA DE MEDIO AMBIENTE, 2007: 43). 

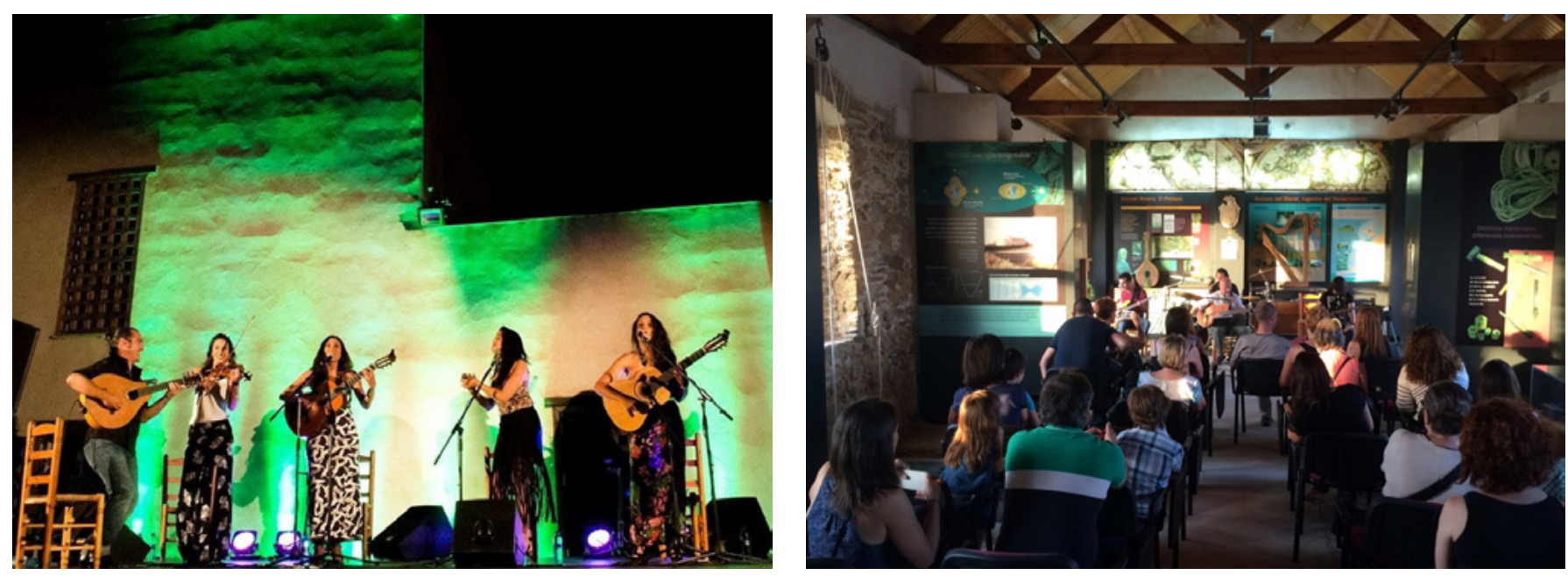

A la izquuierda, actuación de Las Migas en el exterior del Ecomuseo

Actuación de Dasare y Tolajarca en el interior del Ecomuseo | fotos PLATALEA
2. Celebración de efemérides, como el Día Mundial de las Aves, Día Mundial del Medio Ambiente o el Día Mundial de la Música.

3. Otras acciones: conciertos, actividades astronómicas, recitales de poesía, talleres de pan, etc. Sobresalen sin duda los conciertos y festivales, que atraen a numerosas personas. Es el caso del Festival de la luna llena "Lunáticos", que cuenta con actuaciones relevantes en cada edición.

El Ecomuseo Molino El Pintado es un espacio único donde poder conocer de primera mano la vinculación entre el ser humano y la marisma; un lugar donde confluyen naturaleza, historia, etnografía, cultura y tecnología. Un lugar que no puede dejar de visitar. 


\section{BIBLIOGRAFÍA}

- AZURMENDI PÉREZ, L. (1985) Molinos de mar. Santander: Colegio Oficial de Arquitectos de Cantabria, 1985

- AZURMENDI PÉREZ, L.; GÓMEZ CARBALLO, M. A.; MARCHÁN FIZ, S. et ál. (2005) Molinos de mar y estuarios. Litoral Atlántico. Santander: Litoral Atlántico-Asociación para la Conservación de la Arquitectura Tradicional (Tajamar), 2005

- BAS, B. (1991) Muiños de marés e de vento en Galicia. A Coruña: Fundación Pedro Barrié de la Maza, 1991

- CONSEJERÍA DE MEDIO AMBIENTE (2007) Manual de Equipamientos Medioambientales. Uso público en los espacios naturales de Andalucía. Sevilla: Junta de Andalucía, 2007

- CONSEJERÍA DE MEDIO AMBIENTE; GRUPO ENTORNO (2009) Exhibición interpretativa. Ayamonte: Ecomuseo del Molino de El Pintado, 2009

- ECOMUSEU MUNICIPAL DO SEIXAL (2005) Moinhos de Maré do Ocidente Europeu: revalorição do património natural e cultural enquanto recurso de desemvolvimento. En Encontro Moinhos de Maré do Ocidente Europeu 200405. Seixal: Câmara Municipal do Seixal (Portugal), 2005, p. 56

- GONZÁlEZ díAZ, A. M.; JARILLO MÁRQUEZ, F. J.; LÓPEZ ABREU, J. M.; LÓPEZ ABREU, T. (1996) LoS molinos mareales de Ayamonte. Andalucía Educativa, Año I, n. ${ }^{\circ} 3,1996$, pp. 38-39

- GONZÁleZ díAZ, A. M. (2004) Molinos de marea en Ayamonte: un modelo de utilización de los recursos naturales durante la Edad Moderna. En Actas de las VIII Jornadas de Historia de Ayamonte. Ayamonte: Área de Cultura (Ayuntamiento de Ayamonte), 2004, pp. 127-155

- GONZÁlEZ TASCÓN, I. (1992) Fábricas hidráulicas españolas. Madrid: Biblioteca CEHOPU, Centro de Estudios y Experimentación de Obras Públicas (Ministerio de Obras Públicas y Transportes), 1992

- GOZÁLVEZ ESCOBAR, J. L. (1996) Antiguos Molinos de viento, agua y mareales en la provincia de Huelva. Huelva Viva, n. ${ }^{\circ} 2,1996$, pp. 6-15

- JIMÉNEZ MANTECón, J. R. (1917) Platero y yo. León: Everest, 2007

- MADOZ E IBÁÑEZ, P. (1999) Diccionario GeográficoEstadístico-Histórico de España y sus posesiones de Ultramar. (1 ${ }^{a}$ ed. 1847) Huelva: Diputación Provincial, 1999

- MOLINA FONT, J. (2001) Molinos de Marea de la Bahía de Cádiz (siglos XVI-XIX). Cádiz: Junta Rectora del Parque Natural Bahía de Cádiz (Consejería de Medio Ambiente) e Instituto de Medio Ambiente (Mancomunidad de Municipios de la Bahía de Cádiz), 2001
- MOREnO Alonso, M. (2000) Retrato de familia andaluza con las Indias al fondo. El Memorial de El Pintado (1697-1780). Sevilla: Alfar, 2000

- MORENO ALONSO, M.; SOlESIO LILLO, J. (2001) Ayamonte en tiempos de El Pintado (1697-1780). En Actas de las $V$ Jornadas de Historia de Ayamonte. Ayamonte: Patronato Municipal de Cultura (Ayuntamiento de Ayamonte), 2001, pp. 155-173

- ORDEN de 11 de junio de 2010, por la que se inscriben en el Catálogo General del Patrimonio Histórico Andaluz, como bienes inmuebles de catalogación general, de manera colectiva, los molinos mareales del litoral, en los términos municipales que se citan. Boletín Oficial de la Junta de Andalucía, n. ${ }^{0}$ 122, de 23 de junio de 2010

- PARQUE NATURAL DA RIA FORMOSA (1993) Moinho de Maré. Olhão (Portugal): Instituto da Conservação da Natureza, 1993, folleto divulgativo

- Pleguezuelo HeRnÁNDEZ, A. (2005) Manuel Rivero. Los encargos artísticos de una mercader andaluz del siglo XVIII. Huelva: Diputación Provincial, 2005

- POULIQUEN, P. (2005) Moulins en Bretagne. Spézet: Coop Breizh, 2005

- RESOlución de 17 de diciembre de 2008, de la Dirección General de Bienes Culturales, por la que se incoa el procedimiento para la inscripción como Bienes de Catalogación General de manera colectiva en el Catálogo General del Patrimonio Histórico Andaluz, los molinos mareales del litoral de Huelva. Boletín Oficial de la Junta de Andalucía, n. ${ }^{\circ}$ 6, de 12 de enero de 2009

- ROSA SANTOS, L. F. (1992) Os moinhos de mare da Ria Formosa. Quarteira (Algarve; Portugal): Parque Natural da Ria Formosa (Instituto da Conservação da Natureza), 1992

- RUBIO GARCÍA, J. C.; SERVETO AGUILÓ, P. (2004) Molinos mareales del litoral onubense. En Salinas de Andalucía. Sevilla: Consejería de Medio Ambiente (Junta de Andalucía), 2004, pp. 78-79

- RUIZ GONZÁLEZ, J. E. (1999) Los pueblos de Huelva en el siglo XVIII (Según el Diccionario del Geógrafo Real D. Tomás López). Huelva: Diputación Provincial, 1999

- SANZ GARCÍA, I.; CALVENTE COCA, A. (1995) Molinos mareales de Ayamonte. Ayamonte: Escuela-Taller Guadiana (Ayuntamiento de Ayamonte), 1995

- SERVETO AGUILÓ, P.; LÓPEZ RIVERA, J.; GONZÁLEZ MARTíN, D. J. et ál. (2007) El molino mareal de El Pintado: proyecto de rehabilitación como Centro de Interpretación del Patrimonio Cultural y Natural del litoral onubense. En XI Jornadas de Historia de Ayamonte. Ayamonte: Área de Cultura (Ayuntamiento de Ayamonte), 2007, pp. 115-135 


\title{
El legado de Juan Ramón Jiménez en Moguer
}

\author{
Centro de Estudios Juanramonianos \\ URL de la contribución <www.iaph.es/revistaph/index.php/revistaph/issue/view/4253>
}

\section{RESUMEN}

La presencia del autor de Platero aún se hace patente en cada calle, en cada rincón y en cada esquina de su pueblo, Moguer. Hacia 1947, a iniciativa de un grupo de moguereños, se decide homenajear al poeta en el exilio creando una biblioteca pública con su nombre. En 1955, se complementa con un espacio expositivo dedicado al poeta. El matrimonio Jiménez, ilusionado con el proyecto, colabora activamente en la dotación de contenido. El 14 de noviembre de 1958 abre oficialmente al público sus puertas la casa museo.

La casa museo inicia su singladura como espacio museográfico, convirtiéndose en el eje vertebrador de la visita turística a Moguer. En ella se preserva todo el patrimonio que el poeta decide legar a su pueblo: su biblioteca personal de la etapa madrileña, su colección de revistas y periódicos, enseres personales, etc., elementos gracias a los cuales el visitante, al recorrer sus estancias, puede evocar ese Moguer en el que Juan Ramón Jiménez escribió la mayor parte de su producción literaria.

Hoy, el museo se presenta no solo como espacio de contemplación, sino como un instrumento multifuncional, y como eje vertebrador de propuestas en el marco de creación literaria, cultural, pedagógica y turística.

Moguer abarca un conjunto patrimonial imbricado tanto en la vida como en la obra de su poeta. Conocer a Juan Ramón es conocer Moguer. Y conocer Moguer es conocer a Juan Ramón.

\section{Palabras clave}

Casa Museo Zenobia-Juan Ramón Jiménez | Juan Ramón Jiménez | Moguer (Huelva) | Zenobia Camprubí | 


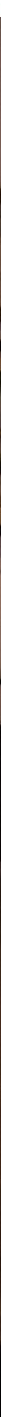

Despacho principal | foto Salvador Aguilar (Fototeca del Centro de Estudios Juanramonianos, titular de todas las imágenes que ilustran este texto) 
1

La casa situada en la Calle Juan Ramón Jiménez n. 10 continúa siendo en la actualidad la sede del museo y de la Fundación Zenobia-Juan Ramón Jiménez.

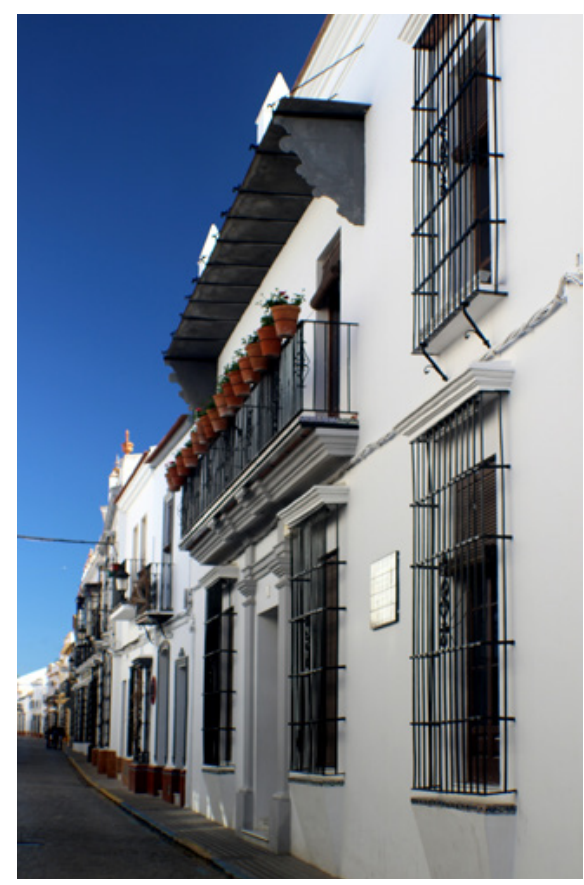

Fachada de la Casa Museo Zenobia-Juan Ramón Jiménez | foto José Manuel Millán
"Moguer, la blanca maravilla, la luz con el tiempo dentro..." (JIMÉNEZ, 2006). Así describía el poeta su pueblo natal, al que llevó durante toda su vida en forma de piedras en su bolsillo, muy cerca del corazón, para no perder el arraigo y la fuerza de su tierra (JIMÉNEZ, 1961). A pesar del paso de los años, la presencia del autor de Platero aún se hace patente en cada calle, rincón y esquina del municipio. Gracias a Juan Ramón, Moguer se universalizó y aún hoy son muchos los que acuden a su pueblo natal en busca de la tácita presencia del Nobel, queriendo ilustrar con imágenes lo que describe magistralmente a través de su obra.

Años antes de que fuese galardonado con el Premio Nobel, en 1947, a iniciativa de un grupo de moguereños, se decide homenajear al poeta en el exilio creando una biblioteca pública con su nombre (INAUGURACIÓN, 1947: 10). En 1955, se complementa con un espacio expositivo dedicado al poeta, que, a elección del autor, se ubicó en la casa familiar donde vivió desde sus cinco años ${ }^{1}$ y cuyas menciones son muy numerosas en sus Elegías andaluzas. También por expreso deseo de Juan Ramón, el nuevo museo se denominaría Casa Museo Zenobia Juan Ramón Jiménez, en homenaje también a su compañera de vida y, gracias al impulso y las gestiones del entonces alcalde de Moguer y diputado provincial, Juan de Gorostidi, la Diputación Provincial de Huelva adquiere el inmueble. El matrimonio Jiménez, ilusionado con el proyecto, colabora activamente en la dotación de contenido con varios envíos y da indicaciones para que casi todos los fondos que se conservaban en el Museo Romántico de Madrid, procedentes del piso de la calle Padilla -que tuvieron que dejar en la salida a su exilio en agosto de 1936fueran a Moguer. Además, destinan la mitad de la dotación económica del Premio Nobel al museo. El 14 de noviembre de 1958 abre oficialmente al público sus puertas la casa museo, tal y como se publica en el diario provincial Odiel Información (FLERY, 1958: 5-6).

La casa museo inicia su singladura como espacio museográfico, convirtiéndose en el eje vertebrador de la visita turística a Moguer. En ella se preserva todo el patrimonio que el poeta decide legar a su pueblo: su biblioteca personal de la etapa madrileña, su colección de revistas y periódicos, enseres, etc., elementos gracias a los cuales el visitante, al recorrer sus estancias, puede evocar ese Moguer en el que Juan Ramón Jiménez escribió la mayor parte de su producción literaria de la etapa española como Platero y yo, Elegías Andaluzas, Apartamiento, Baladas de primavera, Las hojas verdes...

En el año 2000 el inmueble sito en la calle Nueva debe ser cerrado al público para acometer labores de restauración, a la vez que se decide dar un giro y renovar el discurso museográfico adaptándolo a los nuevos tiempos (RAMÍREZ ALMANZA, 2006). De forma provisional, se habilita otro de los espacios juanramonianos de Moguer, la casa donde Juan Ramón Jiménez 


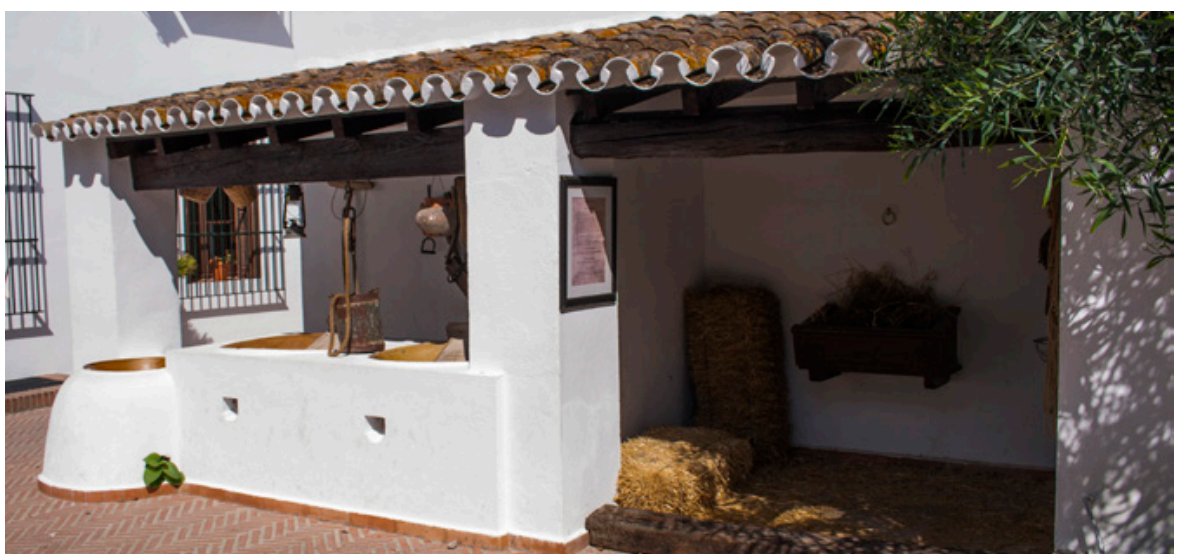

Corral y cuadra de Platero | foto Salvador Aguilar

nace, situada en el barrio de pescadores, en la calle Ribera, para que el legado continuase a disposición del visitante (JIMÉNEZ FERNÁNDEZ, 2006). Son años en los que se trabaja en la rehabilitación del espacio del poeta por excelencia, la casa museo, desarrollándose nuevos discursos museográficos y una nueva ordenación de los fondos del legado juanramoniano (BEJARANO ÁLVAREZ; RODRÍGUEZ DOMÍNGUEZ, 2006).

En diciembre de 2007, concretamente el 26, modernizadas las instalaciones museísticas, puesta al día la gestión y organizadas y digitalizadas todas las colecciones que alberga, abre sus puertas una remozada casa museo que en conjunto ofrece diferentes ámbitos de actuación, concebidos bajo una estructura más innovadora. Se ofrece una nueva visión que, sin perder el sabor de los espacios en los que vivió el poeta, introduce al público en una dimensión lírica, de evocación y conocimientos. Se presenta no solo como espacio de contemplación, sino como un instrumento multifuncional, y como eje vertebrador de propuestas en el marco de creación literaria, cultural, pedagógica y turística (RODRÍGUEZ DOMÍNGUEZ; MUÑOZ MORENO; BEJARANO ÁLVAREZ et ál., 2007).

La rehabilitación de la Casa Museo Zenobia Juan Ramón Jiménez permitió la ampliación de sus salas y asumir nuevas funciones de programación o actividades. Es un nuevo espacio creativo y cultural, donde se entrecruzan los planteamientos tradicionales junto a otros espacios que interpelan al mundo de las nuevas tecnologías multimedia. Se ha articulado otra imagen del legado a difundir.

Como mayoritariamente su público procede del ámbito educativo, el nuevo entorno se pensó como un instrumento pedagógico, intentando llegar a él con aplicaciones didácticas (guías pedagógicas, aulas especiales, talleres literarios, etc.). La casa se concibe como un espacio pedagógico donde cohabita la cultura didáctica de forma recreativa y lúdica.

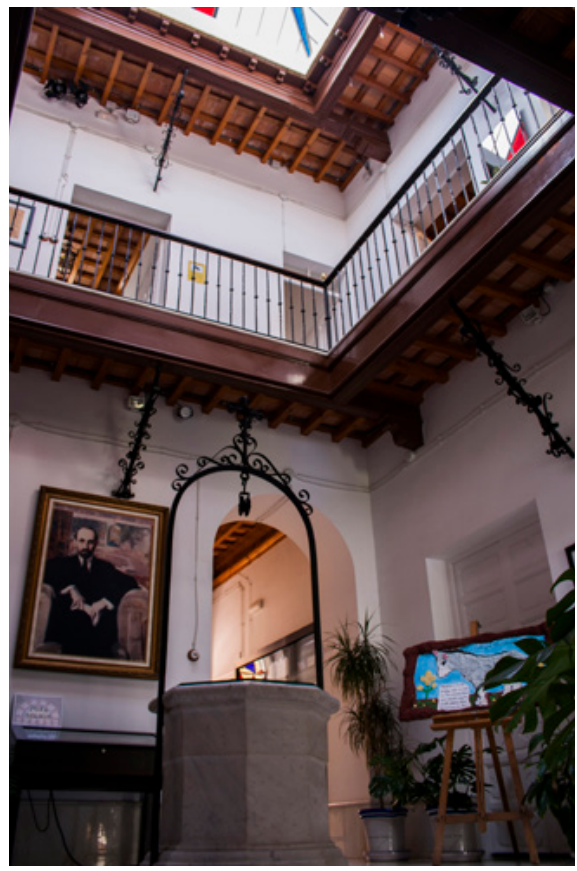

Interior Casa Museo Zenobia-Juan Ramón Jiménez | foto Salvador Aguilar 


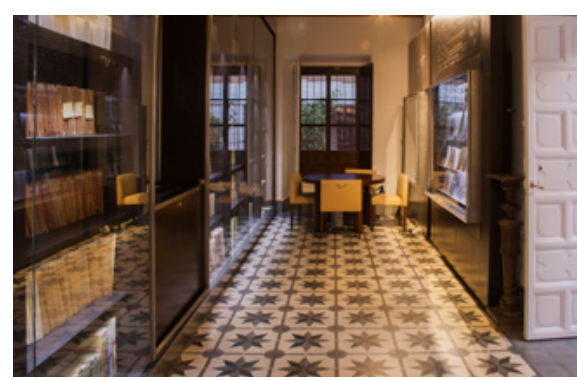

Hemeroteca personal de Juan Ramón Jiménez | foto Salvador Aguilar
2

Espacio web Año Platero <http://www. aytomoguer.es/es/ano-platero/> [Consulta: 21/09/2018]
Uno de los aspectos más importantes de la casa museo, al margen de su sentido de espacio visitable, es el legado que alberga, sus fondos puestos a disposición del investigador. Se articula como un espacio de investigación que tiene como fin último el acercamiento de la cultura bajo el aspecto de la exposición y de la consulta bibliográfica. Uno de los pilares fundamentales para esta faceta ha sido la creación del Centro de Estudios Juanramonianos, centro de documentación en torno a las figuras de Zenobia y Juan Ramón Jiménez, que se encarga de recuperar, adquirir, analizar, custodiar, conservar y difundir todo el patrimonio documental y bibliográfico existente en sus instalaciones.

Resultaría difícil entender hoy cualquier plan turístico de Moguer sin la presencia de la casa museo, no sólo por su faceta como garante del legado juanramoniano y espacio visitable, sino porque todo el municipio conforma el ámbito de creación del poeta. Moguer abarca un conjunto patrimonial imbricado tanto en la vida como en la obra de su poeta. Conocer a Juan Ramón es conocer Moguer, conocer la provincia de Huelva. Y conocer Moguer es conocer a Juan Ramón. Entendemos que ambos, en su universalización literaria e histórica, nos llevan a una oferta turística y cultural de primer nivel.

La promoción turística y cultural de la Casa Museo Zenobia Juan Ramón Jiménez no está exclusivamente en la casa donde vivió, contemplar sus pertenencias personales, muebles, enseres, libros, documentos... Juan Ramón Jiménez ofrece a través de su obra un paisaje, un ambiente, la traza de un Moguer descrito, vivido, con una atmósfera de tiempo y personajes latentes en un pueblo que puede ofrecer lo material e inmaterial del andaluz universal.

Desde el año 2014 en que se celebró el centenario de la primera edición de Platero y yo, se estructuró además una ruta por el patrimonio monumental y literario juanramoniano que se extendió por diferentes espacios de la localidad. Se crea un pasaporte del Año Platero, con el que se insta al visitante a recorrer todo el patrimonio juanramoniano e ir completando etapas para conseguir al final de ellas una edición conmemorativa de dicha obra. En ese recorrido se incluyen espacios como la casa natal de la calle Ribera, la visita al cementerio donde descansan los restos del matrimonio Jiménez, y a monumentos singulares como el monasterio de Santa Clara o la parroquia Nuestra Señora de la Granada. Además, se crea un museo al aire libre, Platero EsCultura, ubicando esculturas de personajes del inmortal Platero como Aguedilla, Darbón, el Tío de las vistas o Platero, en diferentes lugares estratégicos de su casco histórico².

Gracias a esta perfecta simbiosis entre la obra y los lugares donde el poeta desarrolla su actividad creadora, Moguer se ha convertido en el principal referente y epicentro del patrimonio material e inmaterial juanramoniano. 


\section{BIBLIOGRAFÍA}

- BEJARANO ÁlVAREZ, R.; RODRÍGUEZ dOMíngueZ, T. (2006) Juan Ramón Jiménez, su biblioteca personal. Revista Mi biblioteca, n. ${ }^{\circ}$ 7, 2006, pp. 22-28

- FLERY (1958) La Casa Zenobia y Juan Ramón de Moguer abre sus puertas al público. Odiel Información, 18 de noviembre de 1958, pp. 5-6

- INAUgURACIÓN de la nueva biblioteca municipal de Moguer (1947) ABC. Edición de Andalucía, 12 de octubre de 1947, p.10

- JIMÉNEZ, J. R. (2006) Nubes sobre Moguer. Leyenda (1896-2006). Madrid: Visor, 2006

- JIMÉNEZ, J. R. (1961) La Corriente infinita. Crítica y evocación. Madrid: Aguilar, 1961

- JIMÉNEZ FERNÁNDEZ, C. (2006) Un paseo por la casa natal del padre de Platero y yo. Revista Mi biblioteca, n. ${ }^{\circ} 7$, 2006, pp. $16-21$

- RAmírez ALMANZA, A. (2006) Síntesis del proyecto museográfico para la Casa-Museo Zenobia-Juan Ramón Jiménez. Revista Montemayor, 2006, pp. 36-43

- RODRÍGUEZ DOMíNGUEZ, T.; MUÑOZ ROMERO, R.; BEJARANO ÁLVAREZ, R.; GONZÁLEZ ZAPATERO, M. (2007) Casa Museo Juan Ramón Jiménez-Zenobia Camprubí Moguer, Huelva. En III Encuentro Internacional Actualidad en museografía. Mérida, 24-26 de septiembre de 2007. Madrid: ICOM-España, 2008, pp. 61-83 


\section{Una breve incursión por el Carnaval de Isla Cristina, una celebración centenaria}

Agustín P. Figuereo | historiador

URL de la contribución <www.iaph.es/revistaph/index.php/revistaph/issue/view/4348>

\section{RESUMEN}

El Carnaval de Isla Cristina, declarado de Interés Turístico de Andalucía, es la fiesta por antonomasia de la localidad. Celebrada desde el propio origen de la población a mediados del siglo dieciocho, ha ido creciendo a lo largo del tiempo, tanto en duración como en componentes que lo hacen único frente a otros de la zona y conjugando un período especial donde el pueblo se manifiesta tal cual, siendo capaz de enfrentarse abiertamente al poder establecido y demostrando su fuerza.

\section{Palabras claves}

Carnaval | Comparsas | Concurso de agrupaciones | Coros | Fiesta | Isla Cristina (Huelva) | Murgas | 


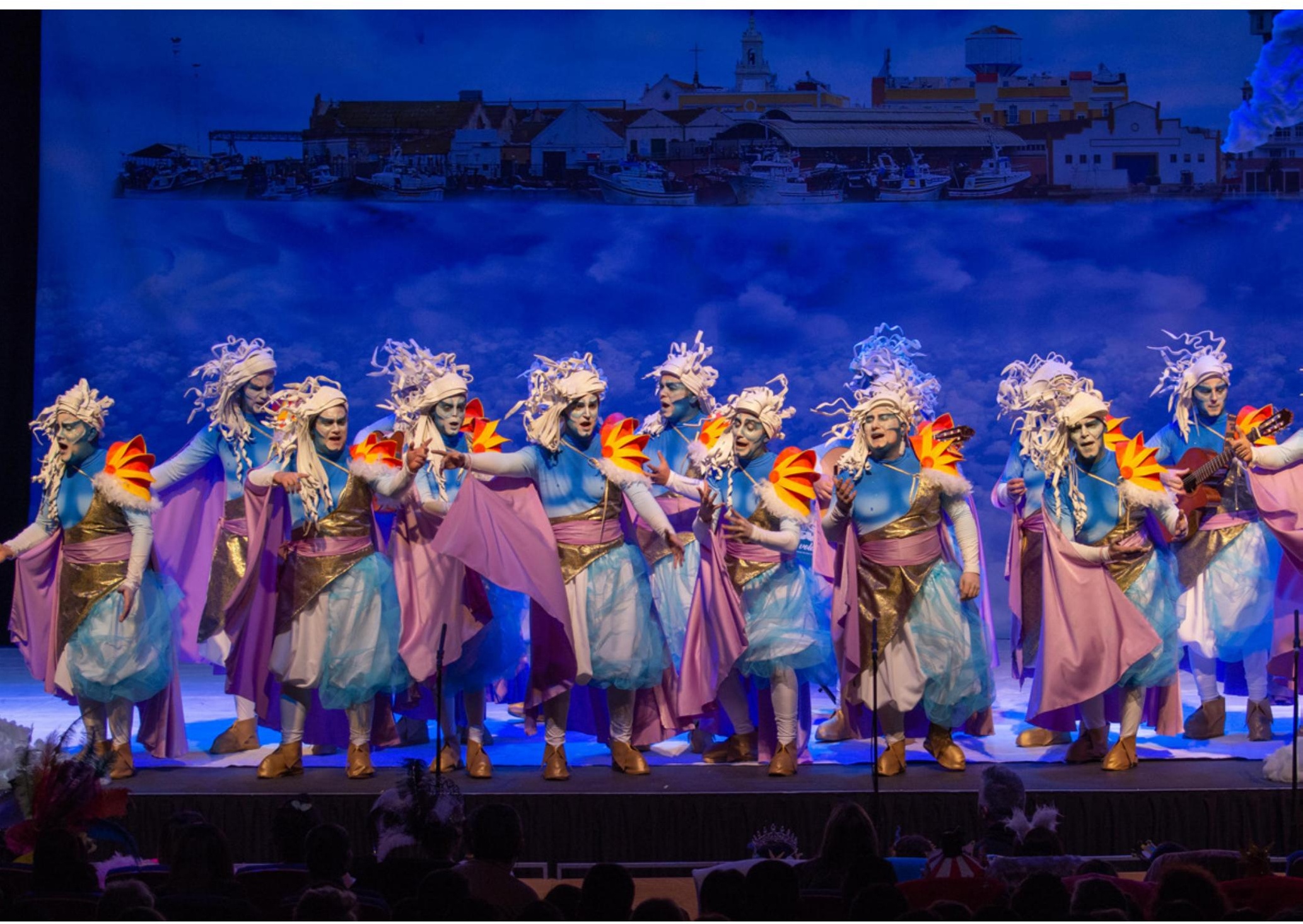

Actuación de una comparsa en el Teatro Municipal "Horacio Noguera" | foto Joaquín Cristóbal, autor de todas las imágenes que ilustran este artículo 
1

Archivo Municipal de Isla Cristina (en adelante, AMIC), Leg. 46, Bando con las normas para la salvaguarda del orden y la moral en la ciudad, 1832

2

AMIC, Leg. 46, Bando, 1858
El Carnaval de Isla Cristina es, sin duda, la fiesta más auténtica y genuina de todas las que se celebran en la localidad.

Tiene su origen, probablemente, en el siglo XVIII, cuando se configura el actual núcleo urbano a raíz del terremoto-maremoto llamado de Lisboa, ocurrido el 1 de noviembre de 1755 . Desde fechas muy tempranas hay constancia de algún tipo de celebración en torno a las fechas de Carnaval, históricamente los tres días anteriores al Miércoles de Ceniza, donde los Ilamados "traficantes de salados" de procedencia catalana y levantina daban por finalizada la temporada en nuestra tierra y emprendían el retorno a sus lugares de origen para volver, de nuevo, en torno a la festividad de San Pedro a finales del mes de junio.

Una vez que la población fue asentándose y consolidándose en el territorio, el Carnaval fue desarrollándose, apareciendo las primeras referencias escritas, de manera transversal, en torno al año 1832, cuando el regidor Lorenzo Elías dicta unas "prevenciones" para proteger la moralidad de los habitantes de la Real Isla. Dos de ellas afectan directamente a nuestra fiesta:

" $33^{a}$. No se prohíben las mascaras y diversiones racionales en los tres días de Carnestolendas autorizadas por el tiempo y la costumbre.

$34^{a}$. No se consideran contenidas en la prevención $33^{a}$ la multitud de prácticas abusivas que ni tienden al placer ni desahogo público ni guarden conformidad con la seguridad personal, el decoro popular, la decencia ni las buenas costumbres"1.

Otro bando, esta vez de 1858, recoge la prohibición de vestir con trajes de ministros de la religión, militares o institucionales, llevar armas o verter aguas fecales sobre los enmascarados. A su vez, se permitía una mayor apertura de los establecimientos de juego y de bebidas, que permanecerían abiertos "hasta el toque de ánimas"2.

En esos años se produce un cambio sustancial en las fiestas, ampliándose su celebración al fin de semana anterior al miércoles de ceniza, además de los tres días ya consabidos, y aunque en 1867 hay un intento de volver a los días concretos, no fue posible conseguirlo por parte de la autoridad.

Isla Cristina, que contaba con un teatro estable al menos desde 1868, incorpora este elemento a su Carnaval a partir de entonces. Desde aquel primitivo teatro, cuyo nombre se desconoce, pero que estaba establecido en la calle San Salvador, hoy denominada Diego Pérez Milá, pasando por el Teatro Flores (levantado por Juan Flores Amo en terrenos de su propiedad en la llamada por él calle Flores) o, ya avanzado el siglo XX, por el Salón Circo 
Victoria, el Gran Vía, el Cine Victoria, el Palacio del Carnaval y, desde principios del siglo XXI, el Teatro Municipal "Horacio Noguera", los diferentes coliseos han jugado un importantísimo papel en las fiestas, primero como lugar de celebración de bailes públicos y luego como sede de un genuino concurso de agrupaciones musicales.

Las ordenanzas municipales de $1876^{3}$ ya recogen formalmente al Carnaval dentro del epígrafe de "Festividades populares", dedicándole doce artícu-
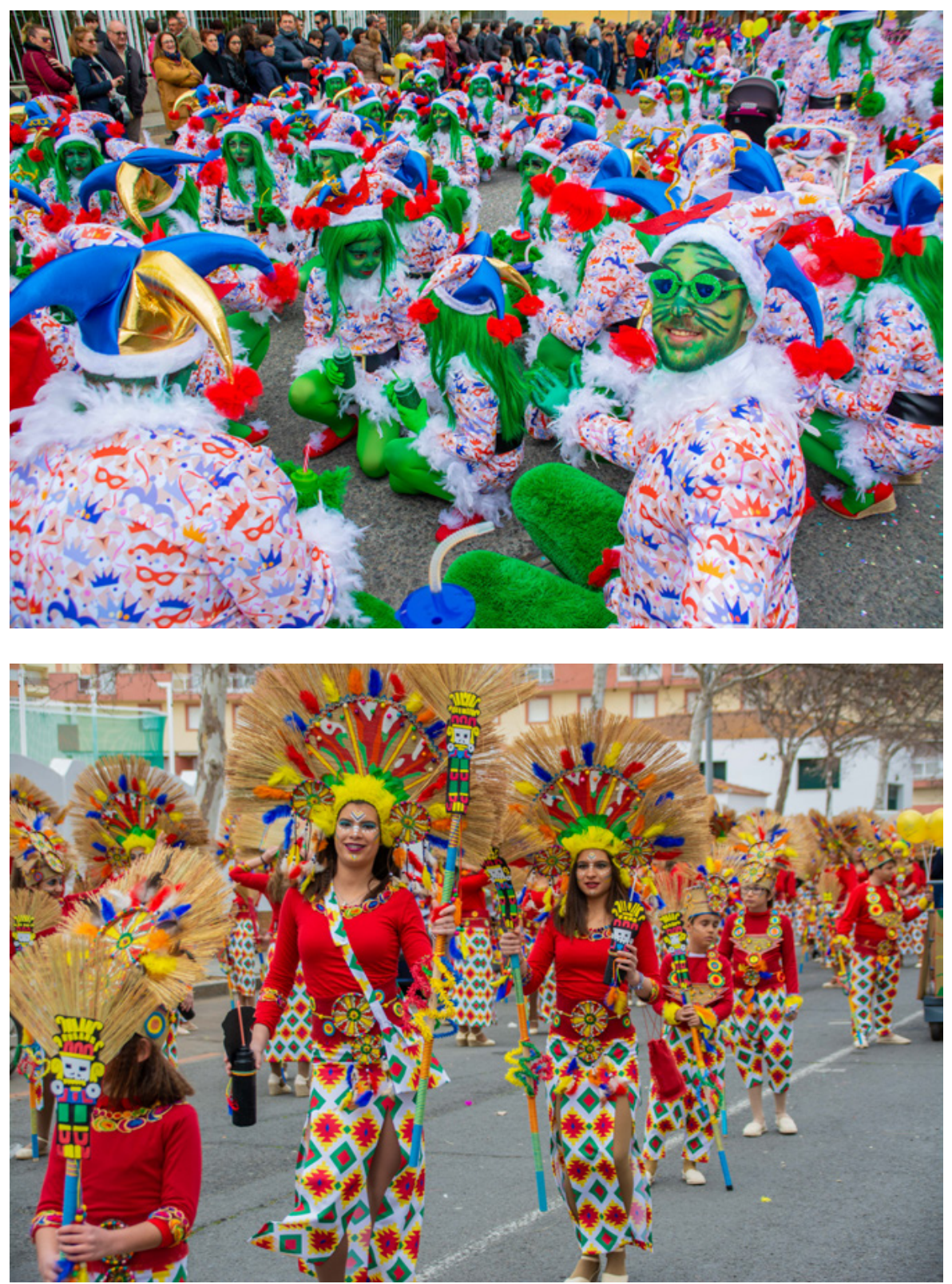

3

AMIC, Leg. 93, Ordenanzas Municipales, 1876.

Grupo de disfraces en la Gran cabalgata 


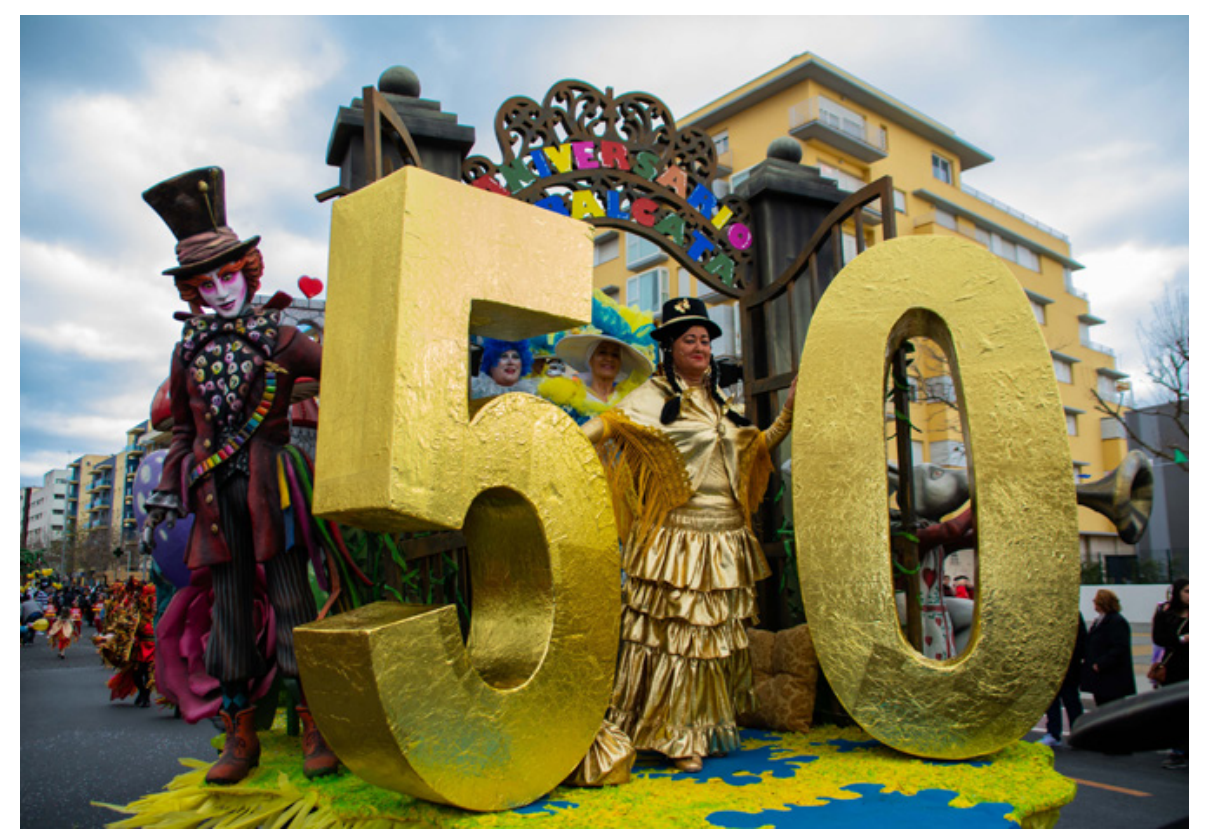

los, donde además de insistir en lo expuesto en bandos anteriores en relación con la prohibición de disfrazarse de miembros del ejército o del clero, de portar armas "o espuelas", arrogaban a la autoridad municipal competente el derecho a desenmascarar a aquellos que cometieran alguna falta, a presidir las funciones del teatro, al comportamiento del público en el mismo $y$, por primera vez, fijaban unas multas que oscilaban entre cinco y diez pesetas.

Contamos ya con el esquema básico por el que será conocido el Carnaval de Isla Cristina: por un lado, la importancia de la calle, de la diversión espontánea de la gente disfrazada dando paseos, gastando bromas y divirtiéndose sanamente, culminando todo ello en el día más importante del Carnaval, el Miércoles de Ceniza, día en el que se celebra el Entierro de la Sardina como verdadero fin de fiestas; de otro, con la aparición del teatro, nacen los bailes de sociedad y también entra en escena el elemento musical.

La influencia que recibe el Carnaval de Isla Cristina es triple, actuando como verdadero lugar donde se produce un choque de culturas: los primitivos fundadores, provenientes del noreste peninsular traen sus celebraciones $y$, casi con total seguridad, aportan el Entierro de la sardina; Cádiz está presente, como capital marítima de la cual dependió la Real Isla de la Higuerita (antigua denominación de Isla Cristina) durante muchísimos años, en la forma de entender las agrupaciones musicales; por último, la cercanía de Portugal, de donde no solo llegaron muchísimos trabajadores sino también la idea de los desfiles, los disfraces más elaborados, etc. 


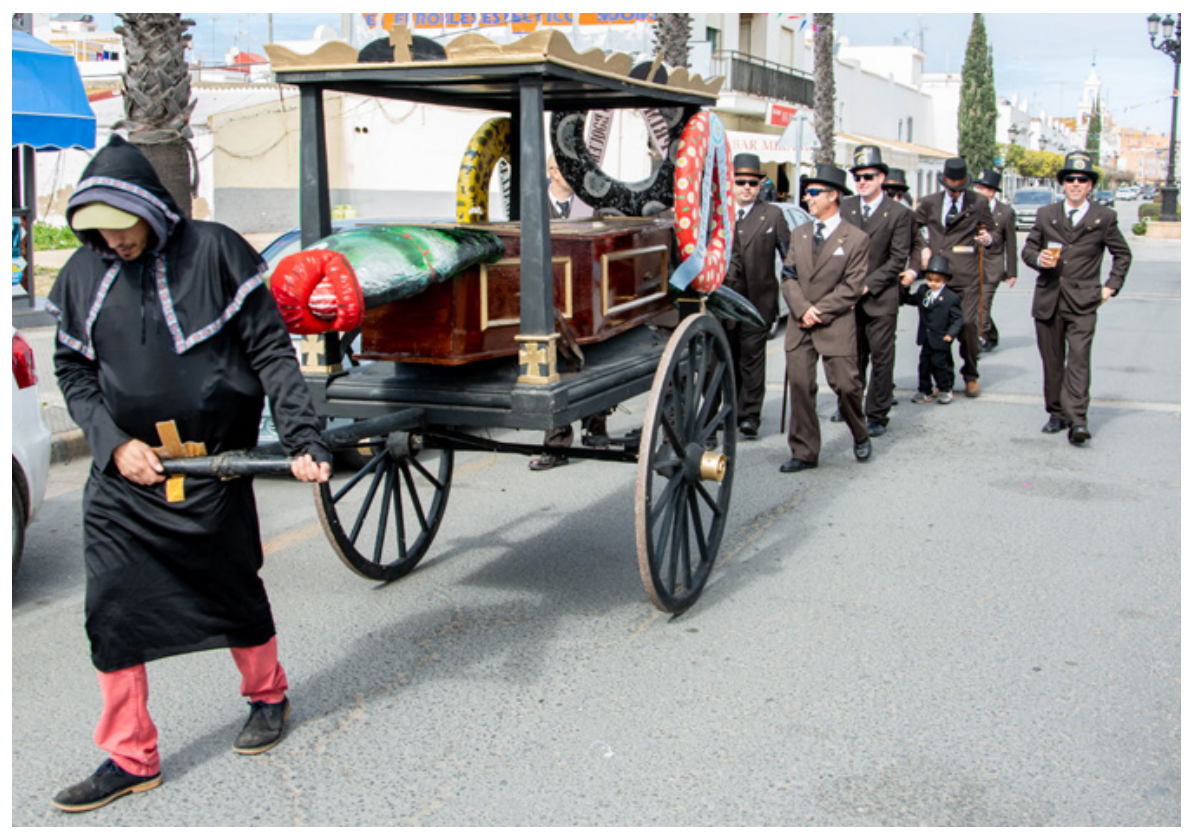

Cortejo fúnebre previo al Entierro de la sardina

Al hilo de la influencia gaditana, por ejemplo, cabe destacar la visita realizada a nuestra ciudad por el mítico coro Los Anticuarios, en la temprana fecha de 1906, en una gira como las que hoy en día se realizan, y que dejó flotando en el aire los sones de aquel mítico tanguillo de "Los duros antiguos". No obstante, la primera letra de carnaval documentada en Isla Cristina se fecha aproximadamente hacia 1880-1881.

Tres modalidades musicales se convertirían en las básicas durante el primer tercio del siglo XX, el coro, la comparsa y la murga. El coro lo conformaban alrededor de cuarenta componentes, acompañados de multitud de instrumentos musicales: violines, guitarras, laúdes, flautas, saxofones, etc.; la comparsa, formada por un número bastante inferior de miembros, llevaban, como hoy, guitarras, bombos y pitos, siendo su repertorio más serio; por último, las murgas aportaban la parte más cómica y grotesca, con letras humorísticas y donde no solía haber instrumentos de cuerda, únicamente bombos, cajas y pitos de caña.

Del año 1919 data una histórica fotografía que recoge dos hechos fundamentales del Carnaval de Isla Cristina, documentando, de una parte, a una comparsa, "Las Regiones Españolas", siendo la primera imagen que tenemos de una agrupación, pero, de otra parte, nos la muestra en una actuación en plena calle, en algo así como la primera carroza que podemos fechar, con la importancia que para la fiesta tiene hoy en día la Gran cabalgata. En dicha imagen los miembros de la comparsa están sobre un carro decorado con los mismos escudos que lucía la agrupación, siendo el carro tirado por un mulo. 


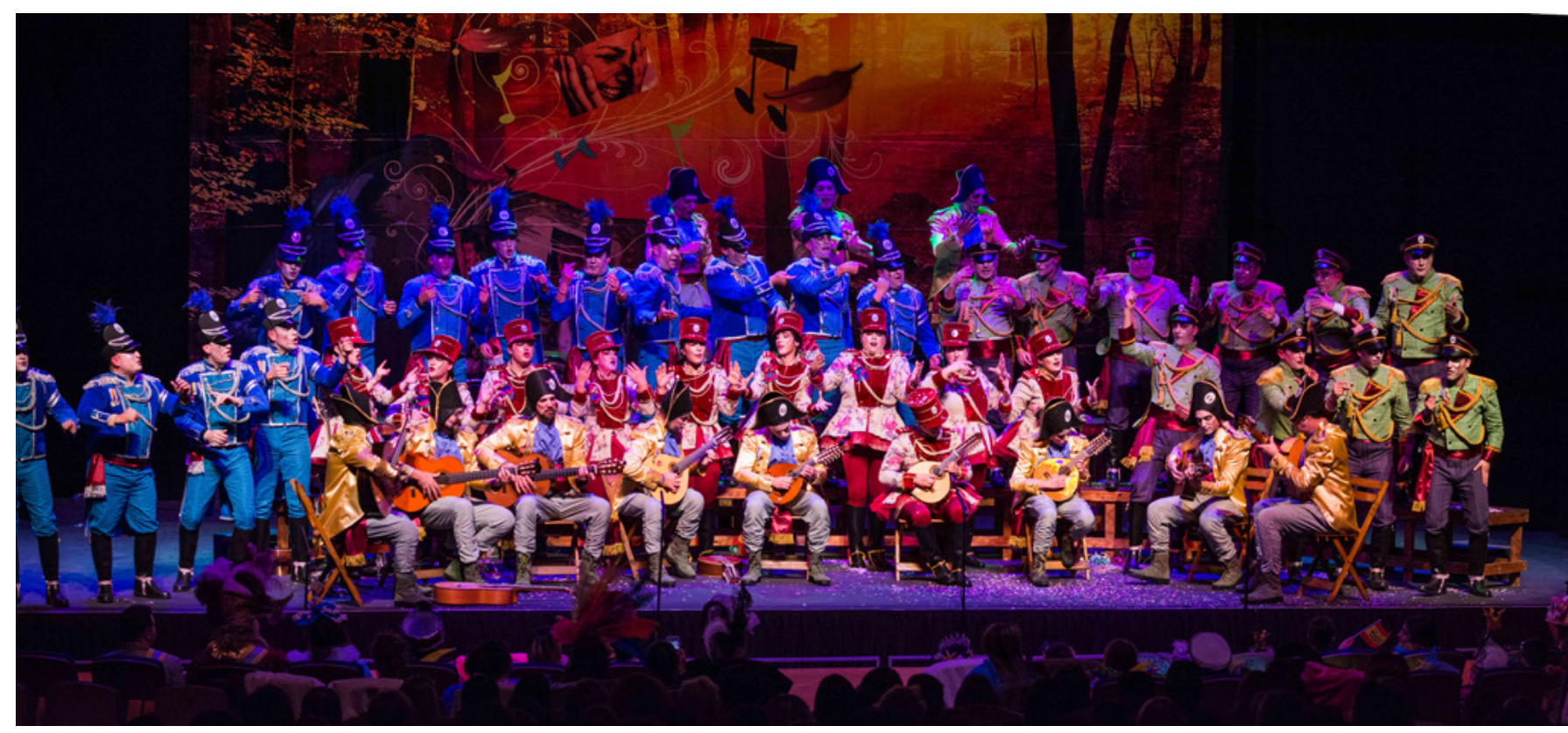

Actuación de un coro en el Teatro Municipal "Horacio Noguera" | foto Joaquín Cristóbal

A partir de entonces nacerán los reñidos concursos entre agrupaciones, a la vez que continuaba celebrándose la calle, ahora alargándose hasta el domingo posterior al Miércoles de Ceniza con la tradicional rotura de piñatas, y los bailes celebrados en teatros, casinos y sociedades de recreo.

La Guerra Civil de 1936 acabaría con todo esto, siendo muchos de los autores y directores más destacados del carnaval fusilados $u$ obligados a marchar al exilio.

Sin embargo, y pese a la prohibición oficial del Carnaval por parte de la dictadura, a partir de mediados de la década de 1940 se conservan los primeros testimonios gráficos de disfraces callejeros, convirtiéndose el salir a la calle en todo un desafío a la autoridad que, sin embargo, fue bastante permisiva.

Las carrozas empezarían a tomar las calles prácticamente una década después, mientras que el concurso de agrupaciones volvió a celebrarse a partir del año 1968 bajo el nombre de Fiestas Típicas de Invierno, siguiendo fiel a su fecha invernal, a diferencia de otras localidades.

El crecimiento del Carnaval, declarado Fiesta de Interés Turístico, ha ido a más, contando con una duración aproximada de tres semanas incluyendo todos sus formatos, desde el concurso de agrupaciones hasta el Domingo de Piñatas, con días que pasan por mayor predilección del público al socaire de las modas y los gustos porque, al final, el carnaval lo hace el pueblo y poco control tiene. 


\section{BIBLIOGRAFÍA}

- BIEDMA VISO, J. (2004) Carnavales de Isla Cristina. $2^{a}$ Ed. Isla Cristina: Ayuntamiento, 2004

- BIEDMA VISO, J. (1992) Carnavales de Isla Cristina (1982-1992). José Biedma Viso, 1992

- FiguereO, A. P. (2001) El Sexenio Revolucionario en Isla Cristina. Boletín de Estudios Históricos ELD, Asociación Cultural El Laúd, Isla Cristina, 2001

- LÓPEZ MÁRQUEZ, V. (2006) Isla Cristina. Por los caminos de la Historia. Huelva: Diputación Provincial, 2006

- SOSA RODRíGuEZ, J. (1970) Historia de Isla Cristina (Biografía sentimental). José Sosa Rodríguez, 1970 


\section{La salina de Biomaris (Isla Cristina). La última instalación artesanal de la costa onubense}

Daniel Martínez Castizo | historiador y antropólogo

URL de la contribución <www.iaph.es/revistaph/index.php/revistaph/issue/view/4256>

\section{RESUMEN}

Desde la antigüedad, la costa de Huelva se ha caracterizado por una intensa y dinámica actividad salinera. Hoy día, la única instalación que de forma activa da fe de dicho pasado es la salina de Biomaris en Isla Cristina. Esta instalación es heredera de la industria salazonera que, desde el siglo XVIII y hasta mediados de siglo XX, transformó la economía del territorio y configuró un particular paisaje de muros, esteros y calentadores en el interior de las marismas onubenses. Para poder sobrevivir a la dura competencia del sector industrial, Biomaris apostó en 2005 por la revalorización del patrimonio paisajístico y cultural salinero, así como por conservar la producción artesanal e introducir nuevos productos.

\section{Palabras clave}

Biomaris | Ecoturismo | Isla Cristina (Huelva) | Producción artesanal | Revalorización | Sal | Salinas | 


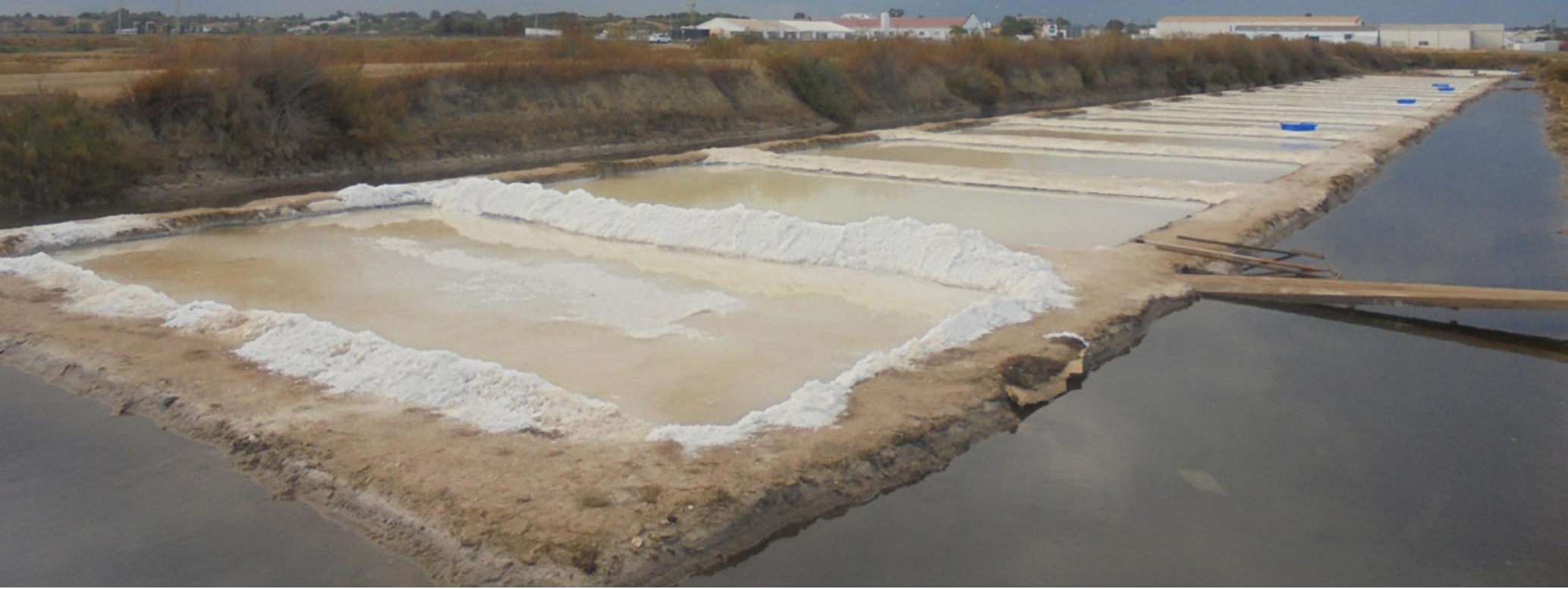

Eras de precipitación desde la que se extrae la Flor de sal | foto Daniel Martínez Castizo, 2017, autor de todas las imágenes que ilustran esta contribución 
En el paraje natural Marismas de Isla Cristina, entre el Caño del Puntal y el Placerón, se encuentra ubicada la salina de Biomaris, la última instalación salinera de la costa onubense que mantiene la actividad tradicional en el cosechado de la sal.

Esta pequeña salina, cuyas dimensiones no van más allá del kilómetro cuadrado, se ha convertido en todo un símbolo de resistencia y representatividad de lo que un día fue el patrimonio salinero en esta parte del Golfo de Cádiz. Y es que, desde Ayamonte hasta la desembocadura del Guadalquivir, entre los siglos XVIII y XIX, la costa se fue plagando de salinas al socaire de la industria salazonera que catalanes y levantinos habían introducido en torno al boquerón, la sardina y el atún.

A comienzos de siglo XX ya se había alcanzado el punto álgido con la consolidación de 22 salinas para, desde la década de los cincuenta, empezar una progresiva decadencia provocada por la reducción de los caladeros, la incapacidad competitiva de las salinas frente a las modernas industriales y la aparición de nuevos métodos de procesado y conservación de alimentos.

Puntualmente se viviría unos años de repunte asociado al hambre de la posguerra que disparó la demanda de sardinas en salazón. Además, el Estado franquista permitió la instalación de sociedades y altos mandos nazis en diferentes sectores productivos como medio de pago económico y político a los préstamos efectuados (372 millones de marcos según convenio MadridBerlín de agosto de 1941), por la Alemania del III Reich.

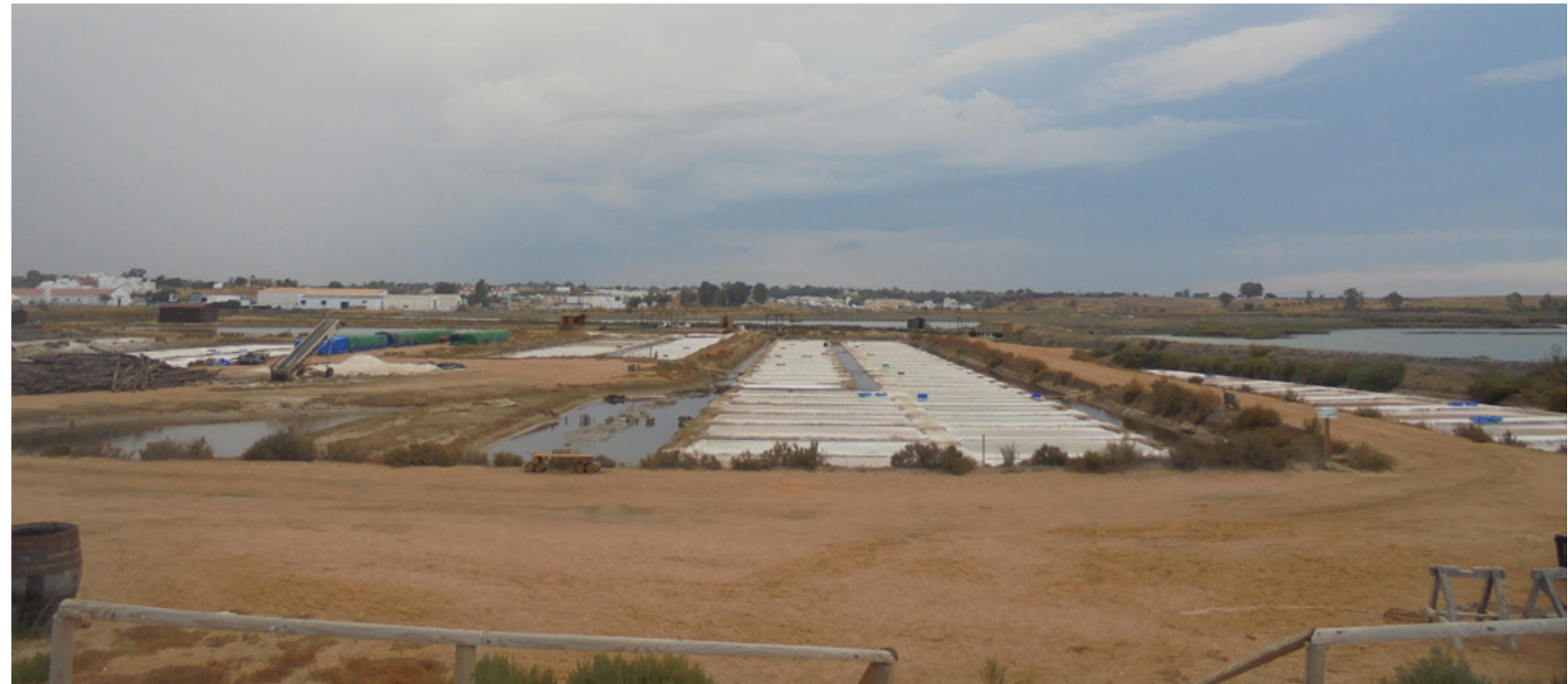




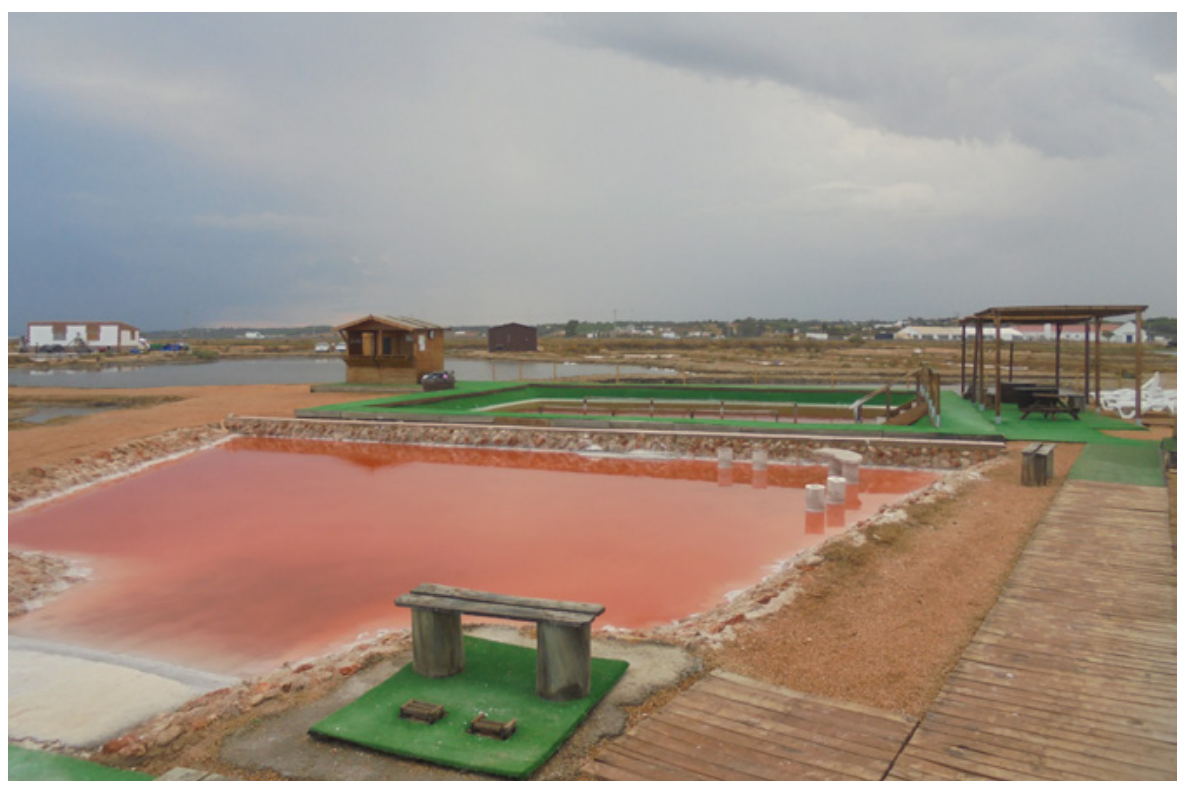

A través de este contexto se explica la aparición en Isla Cristina de Adolf Clauss (jefe de la Abwehr), conocido en la localidad como "Juan El Alemán". En 1954 Clauss llega a la localidad como representante de la empresa de cosméticos alemana Biomaris, una compañía interesada en la obtención de sal para su exportación. Un año después, el "empresario" logra que la salina se encuentre en funcionamiento con la particularidad de que la cristalización, para lograr una mayor pureza en cloruro de sodio, tenía lugar en lebrillos y no en eras de precipitación.

A la muerte de Clauss, es Manuel Rodríguez, maestro salinero de Biomaris, quien se hace con las riendas de las instalaciones y reorienta la producción hacia la sal gorda que puede colocar en las fábricas salazoneras de Isla Cristina y Ayamonte. Durante casi 40 años mantiene viva las instalaciones, asiste a la desaparición del resto de salinas artesanales -convirtiéndose así en el único ejemplo activo del pasado salinero onubense-, y contempla con resignación la aparición de un duro competidor industrial como es Marismas del Odiel.

En 2003 la propiedad pasa a su hija Manuela, quien para sostener la herencia se suma a la incipiente generación de nuevos salineros del medio rural que, como en el resto de Europa, reorientan la producción hacia nuevos productos y aprovechamientos.

Para ello y, en primer lugar, decide mantener como seña de identidad la producción artesanal con la creación de la sociedad "Flor de Sal Salinas de Isla Cristina-Biomaris", a través de la cual apostará por la calidad y no la can-

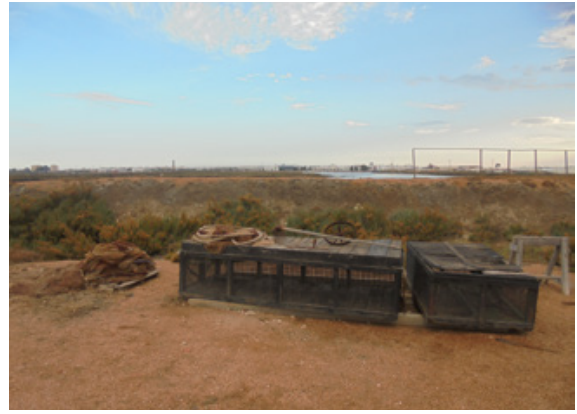

Aperos tradicionales de cosecha y pesca 


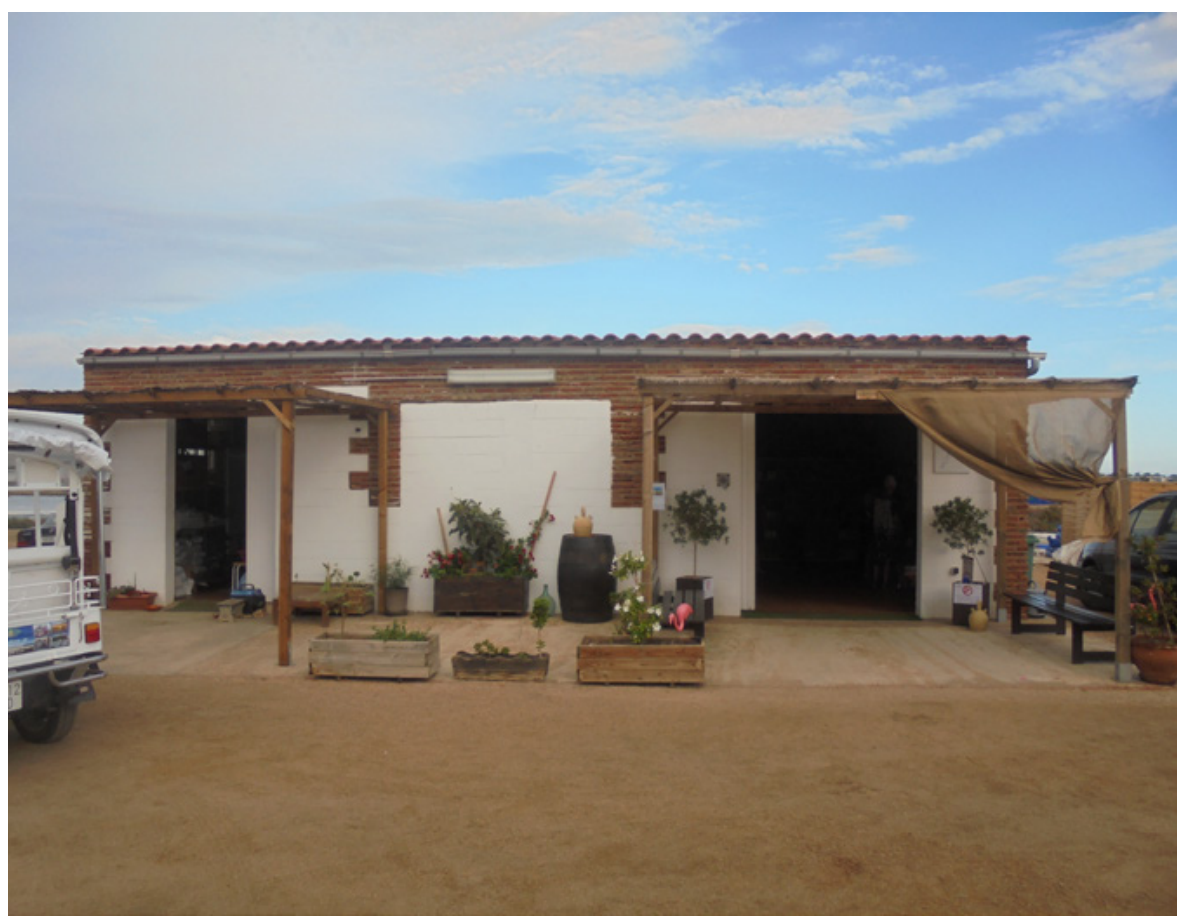

tidad. Posteriormente se centra en la revalorización de las potencialidades naturales del entorno (visitas guiadas y talleres de sal); también amplía la oferta de servicios (baños de magnesio); así como la línea de productos derivados de la sal (flor y escamas de sal; salmuera, aceite, sal y jabón de magnesio; y hasta 35 tipos de sal con distintas especias). En definitiva, apuesta por un aprovechamiento responsable y sostenible del medio natural del que salen casi 300 T/año de sal artesanal.

Además, desde 2011, Biomaris pasó a formar parte (junto con otras 10 salinas de España, Francia, Portugal y Reino Unido), del proyecto EcoSal Atlantis a través de la Ruta Sal Tradicional Ruta del Atlántico. Este programa, cuya base fundamental es la potenciación del ecoturismo y la consolidación así de la actividad en el territorio, pone de relieve la mejora de la gestión de los respectivos paisajes salinos mediante la investigación, el intercambio de experiencias y la colaboración de las instituciones y agentes locales.

De esta forma, la salina de Biomaris, sin renunciar a su legado patrimonial pues las instalaciones siguen siendo las mismas que entre muros de piedra y salicornia se viene trabajando desde hace más de 60 años-, y mediante un inteligente proceso de revalorización y diversificación, ha logrado consolidarse y ser reconocida como una de las actividades económicas más importantes de la provincia de Huelva. 


\section{BIBLIOGRAFÍA Y OTRAS FUENTES}

- ECOSAL ATLANTIS <http://ecosal-atlantis.ua.pt/ index.php?q=es/content/lista-de-actividades> [Consulta: 05/09/2018]

- FLOR DE SAL BIOMARIS <http://flordesalbiomaris. com> [Consulta: 05/09/2018]

- GOZÁLVEZ ESCOBAR, J. L. (2017) El final de las salinas artesanales. En CAMPOS, J. M. (coord.) El patrimonio histórico y cultural en el Paraje Natural Marismas del Odiel. Huelva: Servicio de Publicaciones de la Universidad de Huelva, 2017, pp. 390-404

- PAISAJE de Interés Cultural pesquero de Isla Cristina (Huelva) [en línea] Instituto Andaluz del Patrimonio Histórico, $2005<$ http://www.iaph.es/export/sites/default/ galerias/patrimonio-cultural/documentos/paisaje-cultural/ huelva/paisaje_interes_cultural_pesquero_isla_cristina_ huelva.pdf> [Consulta: 05/09/2018]

- PATRIMONIO cultural en los puertos de interés pesqueros en Andalucía. Isla Cristina (2013-2015) [en línea] En Atlas del Patrimonio Cultural en los Puertos de Interés Pesquero de Andalucía. Universidad de Sevilla, Consejería de Fomento y Vivienda. Agencia Pública de Puertos de Andalucía, 2013-2015 <http://grupos.us.es/ puertosandaluces/pdf/Ficha_IslaCristina.pdf> [Consulta: 05/09/2018]

- RUBio garcía, J. C.; SERVETO AGUILÓ, P. (2004) Historia de las salinas del Golfo de Cádiz. En PÉREZ, A. (coord.) Salinas de Andalucía. Sevilla: Junta de Andalucía, 2004, pp. 42-46

- Rubio garcía, J. C.; SERVETO AGuiló, P. (2004) Tipos funcionales de las salinas atlánticas: salinas artesanales y salinas industriales. En PÉREZ, A. (coord.) Salinas de Andalucía. Sevilla: Junta de Andalucía, 2004, pp. 177-190

- SOlER GARCÍA, M. Espionaje en Huelva: Operación Mincemeat. El hombre que nunca existió [en línea] <http://www.culturandalucia.com/gce/operaci\%C3\%B3n mincemeat_el_hombre_que_nunca_existi\%C3\%B32.htm> [Consulta: 05/09/2018] 


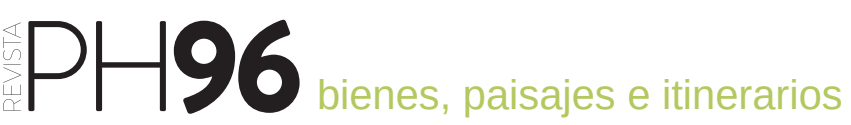

\section{Huelva y costa occidental en el IAPH}

Huelva y la costa occidental es una demarcación paisajística que se localiza en el suroeste de Andalucía. Los municipios que comprende esta demarcación son Ayamonte, Isla Cristina, Lepe, Cartaya, Aljaraque, Gibraleón, Huelva, San Juan del Puerto, Moguer, Palos de la Frontera y Punta Umbría.

A través de la Guía Digital del Patrimonio Cultural de Andalucía (https://guiadigital.iaph.es/inicio), se podrá encontrar la información de patrimonio mueble, inmueble, inmaterial y paisajes culturales, además de otros contenidos como rutas culturales, imágenes, referencias bibliográficas, productos multimedia y obras restauradas de esta demarcación.

URL de la contribución <www.iaph.es/revistaph/index.php/revistaph/article/view/4349>

\section{Patrimonio inmueble}

En la Guía Digital del Patrimonio Cultural se encuentra la información referida a un total de 809 inmuebles de esta demarcación, de los cuales el $48 \%$ corresponden al patrimonio arqueológico, el $42 \%$ al arquitectónico y el $9 \%$ al etnológico.

\section{Patrimonio mueble}

En la mencionada guía se puede consultar la información referida a 796 objetos muebles de carácter artístico en la costa occidental de Huelva distribuidos en diez municipios. Algunos de estos bienes pertenecen al Inventario de Bienes Muebles de la Iglesia Católica; otros

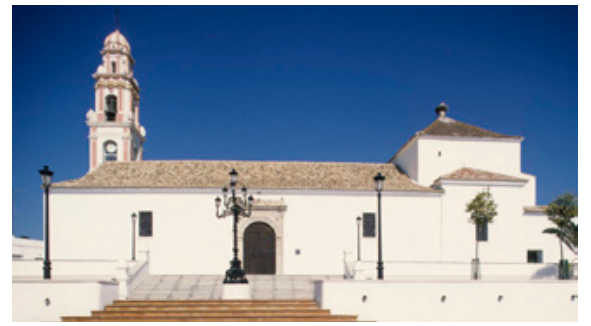

Iglesia de Nuestro Señor y Salvador.en Ayamonte foto Fondo Gráfico IAPH (Javier Romero García) a la obra escultórica de Antonio León Ortega en la provincia de Huelva, que se encuentran inscritos como bienes de catalogación general de manera colectiva en el Catálogo General del Patrimonio Histórico de Andalucía.

\section{Patrimonio inmaterial}

Respecto a los bienes de patrimonio inmaterial que podemos consultar, encontramos un total de 24 registros, de los cuales diez corresponde al ámbito de rituales festivos, otros diez al de oficios y saberes, dos a modos de expresión y otros dos de alimentación.

Las actividades relacionadas con el mar son las que tienen una mayor presencia entre los registros existentes, así como actividades estrechamente relacionadas con estos trabajos. La venta de pescado en Ionja, las salinas, la recogida de coquinas o la elaboración de guiso marinero, son algunos ejemplos de esto. Respecto a los rituales festivos, podemos encontrar ejemplos como la

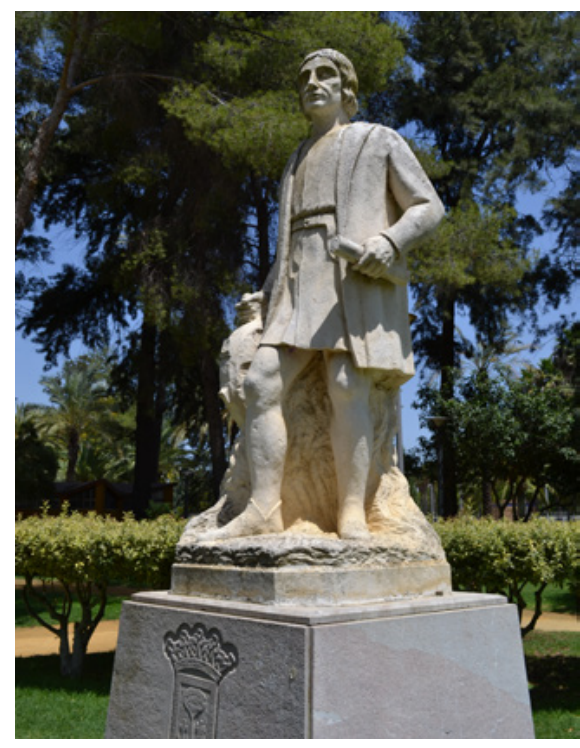

Monumento a Alonso Sánchez (Antonio León Ortega, 1970) en Huelva | foto Fondo Gráfico IAPH (Juan Antonio Arenillas Torrejón)

Semana Santa de Cartaya, la romería de la Virgen Bella o los carnavales.

\section{Paisajes culturales}

Al suroeste de la provincia de Huelva, entre el sur del Andévalo y la costa, se extiende un territorio llano poblado de pinares y ocupado con plantaciones de cítricos y culti- 
vos intensivos de invernadero en el que se ha delimitado la demarcación paisajística de Huelva y costa occidental.

En este espacio, la mayor parte de los asentamientos se concentran al oeste, en el entorno de la capital, y al noreste, en el eje GibraleónAyamonte, cercano al Algarbe portugués. Entre estas dos zonas, un vasto espacio avanza hasta el mar convirtiéndose en amplias marismas, mayoritariamente concentradas en las desembocaduras de los ríos Odiel y Tinto, en las proximidades de la capital; del río Piedras, bajando entre Lepe y Cartaya hasta El Rompido y El Portil; y en los esteros del Guadiana, cercanos a Isla Cristina y Ayamonte. Esta demar-

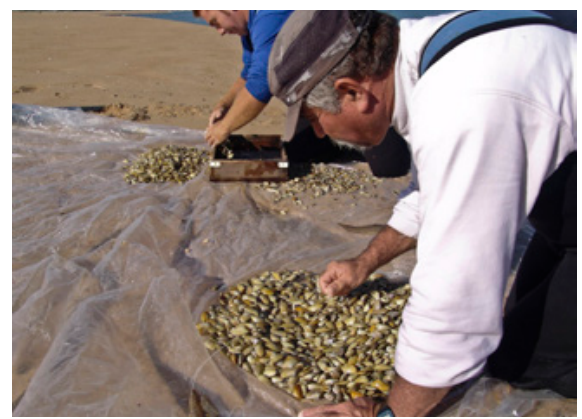

Marisqueo a pie en Cartaya | foto Fondo Gráfico IAPH (Alberto Granados Román)

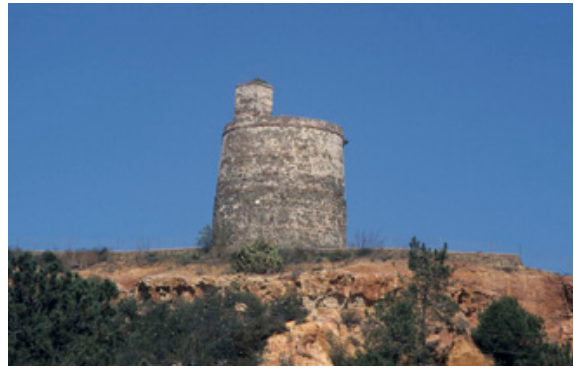

Torre del Catalán en Lepe | foto Fondo Gráfico IAPH (Javier Romero García) cación conserva un medio de gran singularidad paisajística y valor medioambiental que conecta con las playas alineadas en la práctica totalidad de la costa, entre la desembocadura del Guadiana, en la frontera con Portugal, y el término de la localidad de Mazagón, donde contactan con el entorno del Parque Nacional de Doñana.

En esta demarcación paisajística de Huelva y costa occidental ha quedado identificado el siguiente paisaje de interés cultural de Andalucía: paisaje pesquero de Isla Cristina.

\section{Rutas culturales}

En la guía digital hay una ruta cultural de la cual una parte se encuadran en la zona que estudiamos: La arquitec- tura defensiva en la costa andaluza, que constituye un rico patrimonio inmueble íntimamente ligado a los núcleos de población, que en ocasiones nacen a su amparo, y en otras, por su existencia previa, justifican la construcción de estas tipologías arquitectónicas.

Las diversas disputas que existían entre Castilla y Portugal propiciaron que en Huelva desde la Baja Edad Media se realizaran multitud de esfuerzos para la creación de espacios defensivos costeros.

\section{Bibliografía}

En cuanto a la bibliografía, podemos encontrar en el repositorio de activos digitales un total de 895 referencias bibliográficas sobre la costa occi-

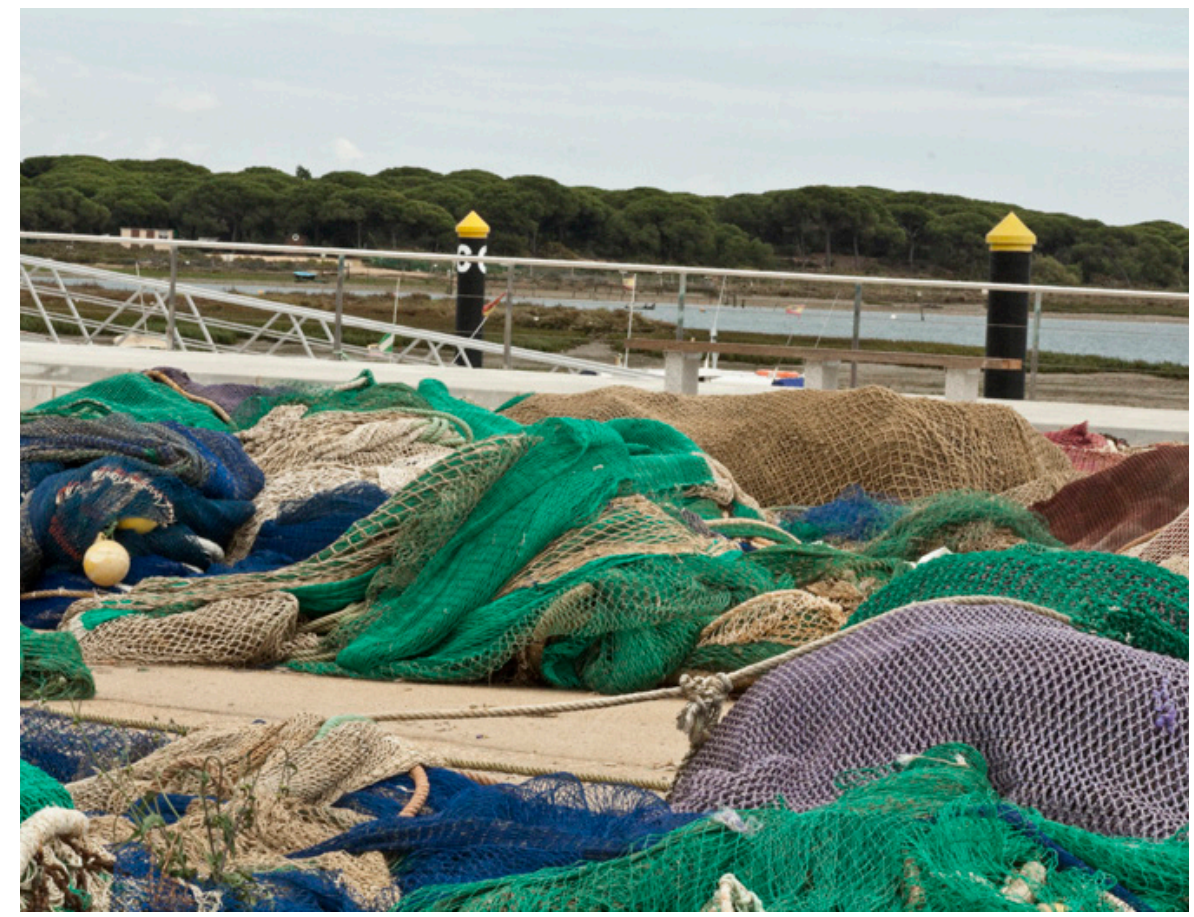

Confección de redes de pesca en Punta Umbría (Huelva) | foto Fondo Gráfico IAPH (María del Rosario Ortiz Amores) 
dental de Huelva. El municipio que posee mayor cantidad de referencias es Huelva (535), seguido de Palos de la Frontera (75) y Moguer (65).

\section{Cartografía}

Se encuentran georreferenciados en la zona un total de 320 inmuebles, 104 son puntuales y 216 poligonales, algunos de los cuales pueden consultarse a través del localizador cartográfico del patrimonio cultural.

\section{OBRAS RESTAURADAS}

\section{Materiales arqueológicos de la} necrópolis de La Joya

La necrópolis de La Joya, ubicada en el cabezo del mismo nombre en la ciudad de Huelva, constituye uno de los referentes fundamentales sobre el mundo funerario del periodo orientalizante en la Península Ibérica, no sólo por la riqueza y calidad de los ajuares en ella localizados, sino también por la diversidad en los rituales y tipologías de las estructuras funerarias documentadas.

Según se desprende del estudio de los materiales, su cronología puede establecerse desde la segunda mitad del siglo VIII a. de C. hasta la primera mitad del siglo VI a. de C., presentando un margen temporal de uso de unos dos siglos aproximadamente. La riqueza tecnológica y artística de algunas piezas del ajuar funerario, en su mayoría fabricados en bronce, halladas en las distintas campañas de excavación, y su delicado estado de conservación, impulsaron la ejecución de un proyecto para el estudio, conservación y museali- zación de los materiales depositados en el Museo de Huelva. De esta forma, se inició la restauración-conservación de una parte de los mismos en las dependencias del IAPH en 2006. La vasta información obtenida durante su desarrollo demuestra la importancia de esta necrópolis y sus amplias posibilidades de estudio. Por esta razón, en el año 2010 se desarrolló como proyecto de I+D. Poniendo de manifiesto que, a pesar de ser un yacimiento referente en la Protohistoria peninsular, aún existen numerosos interrogantes que las nuevas investigaciones deberán desvelar.

\section{Crucificado del Cementerio}

El Cristo del Cementerio es una de las imágenes de Jesús Crucificado más antigua de la provincia de Huelva por ello sorprende la escasa información que se conoce sobre su origen e historia existiendo varias hipótesis al respecto. Fue estudiada y posteriormente intervenida en el Instituto Andaluz del Patrimonio Histórico durante los años 2009 y 2010. Dicha actuación daba respuesta a la petición realizada por el Ayuntamiento de la localidad onubense de Gibraleón, propietario de la obra.

Es una escultura de madera de álamo tallada y policromada cuya ejecución se puede encuadrar entre finales del siglo XIV y principios del $\mathrm{XV}$, habiendo sido objeto de algunas intervenciones posteriores derivadas de su continua readaptación a nuevos contextos y/o usos.

Posee un notable interés histórico-artístico además de un signifi-

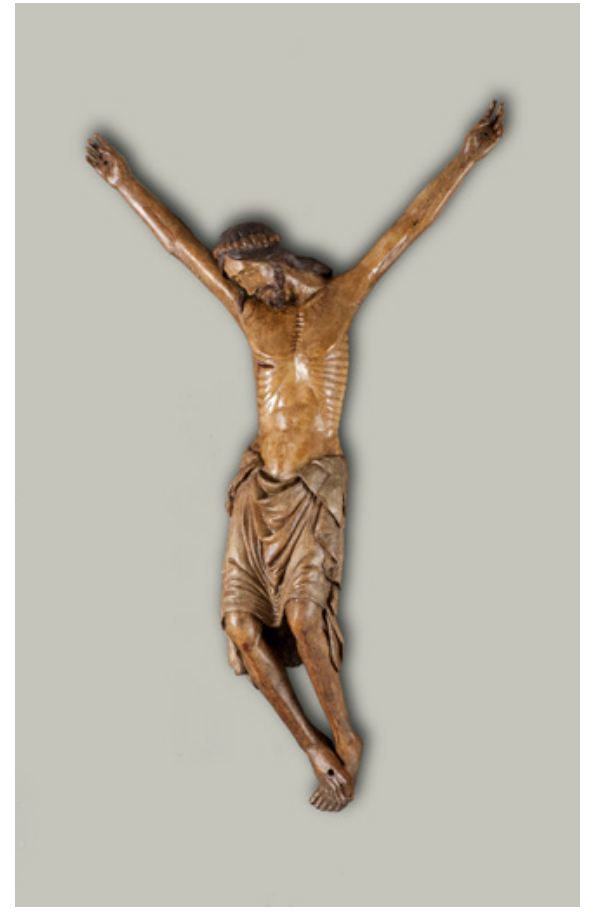

Crucificado del Cementerio de Gibraleón | foto Fondo Gráfico IAPH (Eugenio Fernández Ruiz)
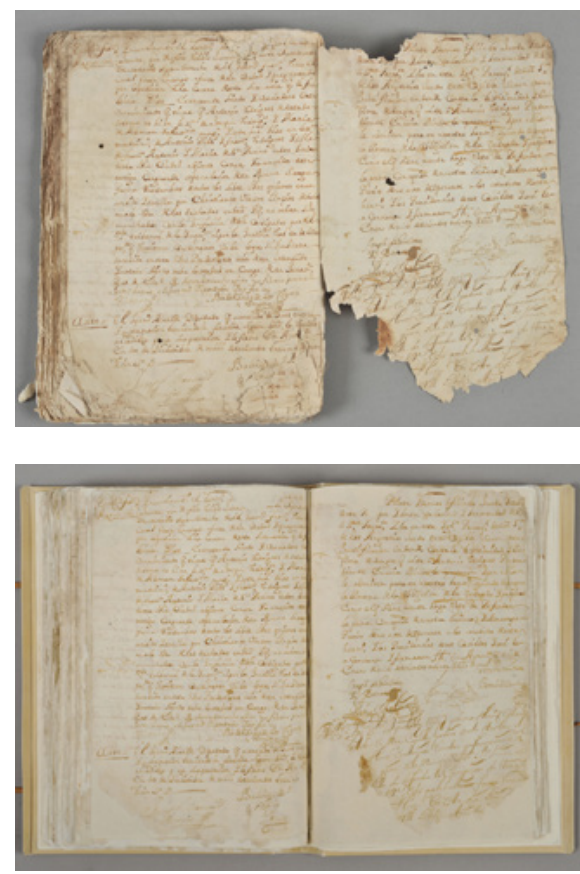

Expediente de Limpieza de Sangre. Ayamonte. Estado inicial (arrriba) y final (debajo) | foto Fondo Gráfico IAPH (Eugenio Fernández Ruiz) 
cativo aprecio social. Está incluida en el Inventario General de bienes Muebles del Patrimonio Histórico Español, según lo dispuesto en la Ley 14/2007 de 26 de noviembre de Patrimonio Histórico de Andalucía, disposición adicional sexta.

\section{Expedientes de Limpieza de Sangre en Ayamonte}

El IAPH restauró en 2010 dos interesantes volúmenes propiedad de la Cofradía Sacramental de las Angustias, cedidos en calidad de depósito permanente al Archivo Municipal de Ayamonte.

Se trata de una colección de Expedientes de Legitimidad y Limpieza de Sangre comprendidos entre los años 1725 y 1760, pertenecientes a la entonces cofradía ayamontina del Santo Sacramento de Ayamonte antes de su fusión con la cofradía del Descendimiento.

Aunque este tipo de expedientes constituye un tipo documental difícil de localizar entre los fondos de cofradías y hermandades religiosas, fue una práctica muy extendida entre estos colectivos. La idea de documentar el origen y procedencia de los individuos y su legitimación como "cristianos puros" fue un requisito indispensable para la admisión en cualquier colectivo público religioso, civil o militar en España desde el siglo XV hasta su supresión por Real Orden en 1835.

\section{Un plano de Isla Cristina}

El Archivo Municipal de Isla Cristina conserva una copia del plano general de la población realizado en 1922 , por orden del ayuntamiento isleño, por el entonces ayudante de obras públicas de la Jefatura Provincial de Isla Cristina, Carlos Rubio.

Durante las primeras décadas del siglo $\mathrm{XX}$, surgió el debate sobre el planeamiento urbano y la necesidad de una gestión municipal más eficaz, promoviéndose la ampliación de las competencias municipales para la mejor y más racional gestión urbanística que desembocaría en los nuevos planes urbanísticos encaminados a optimizar el espacio y encauzar racionalmente el crecimiento de las ciudades.
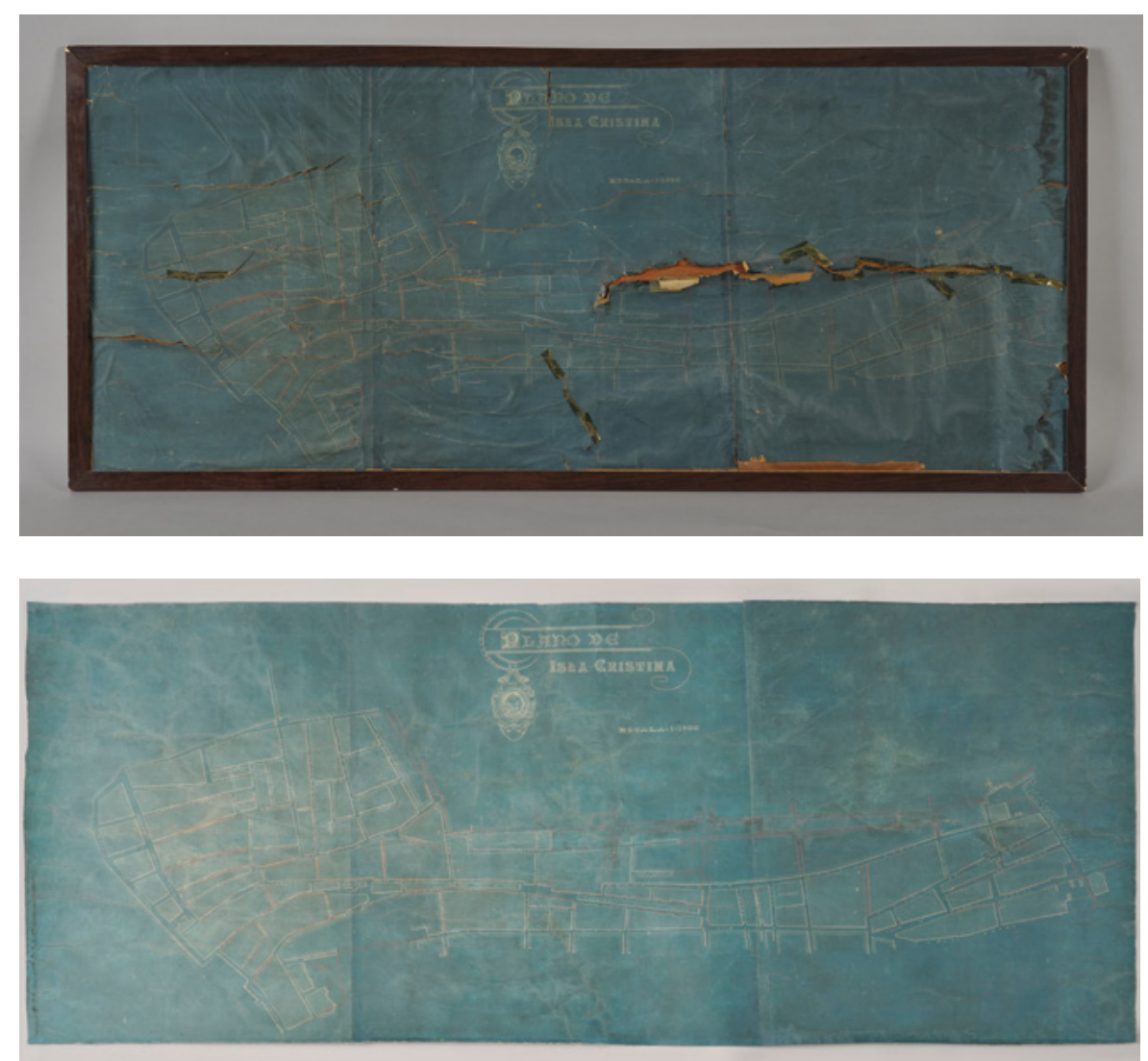

Plano de Isla Cristina. Estado inicial (arriba) y final (debajo) | foto Fondo Gráfico IAPH (Eugenio Fernández Ruiz)
El plano de Isla Cristina, restaurado en el IAPH en 2011, es un ejemplo de estas nuevas políticas. Realizado a escala 1:1000, su particularidad principal es el uso de un papel de fabricación industrial denominado cianotipo o ferroprusiato, que otorga el aspecto de un dibujo en blanco resaltado sobre un fondo azul fuerte.

El uso de este papel se generalizó comercialización en grandes rollos que posibilitaba todo tipo de formatos, fue muy empleado en la reproducción de mapas y planos, hasta su desuso a mediados del siglo XX. hacia 1880, y por su bajo coste y su 